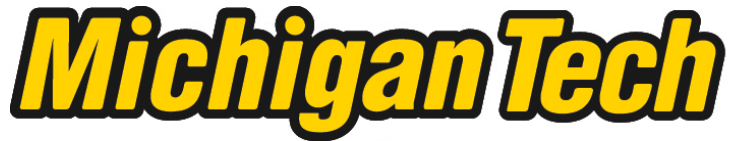 \\ Michigan Technological University Create the Future Digital Commons @ Michigan Tech
}

Dissertations, Master's Theses and Master's Reports - Open

Dissertations, Master's Theses and Master's

Reports

2013

\section{Living with Differences: From Everyday Fundamentalisms to Invitational Communication}

Lisa M. Watrous

Michigan Technological University

Follow this and additional works at: https://digitalcommons.mtu.edu/etds

Part of the Biblical Studies Commons, Communication Commons, and the Philosophy Commons Copyright 2013 Lisa M. Watrous

\section{Recommended Citation}

Watrous, Lisa M., "Living with Differences: From Everyday Fundamentalisms to Invitational Communication", Dissertation, Michigan Technological University, 2013.

https://doi.org/10.37099/mtu.dc.etds/631

Follow this and additional works at: https://digitalcommons.mtu.edu/etds

Part of the Biblical Studies Commons, Communication Commons, and the Philosophy Commons 


\title{
LIVING WITH DIFFERENCES: FROM EVERYDAY FUNDAMENTALISMS TO INVITATIONAL COMMUNICATION
}

By

Lisa M. Watrous

\begin{abstract}
A DISSERTATION
Submitted in partial fulfillment of the requirements for the degree of DOCTOR OF PHILOSOPHY

In Rhetoric and Technical Communication
\end{abstract}

MICHIGAN TECHNOLOGICAL UNIVERSITY

2013

(C) 2013 Lisa M. Watrous 
This dissertation has been approved in partial fulfillment of the requirements for the Degree of DOCTOR OF PHILOSOPHY in Rhetoric and Technical Communication.

Department of Humanities

Dissertation Co-Advisor:

Dissertation Co-Advisor:

Committee Member:

Committee Member:

Department Chair:
Dr. Patricia Sotirin

Dr. Stephen Pluháček

Dr. Robert Johnson

Dr. Ramsey Eric Ramsey

Dr. Ronald Strickland 
Table of Contents

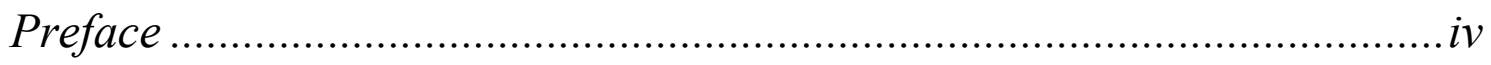

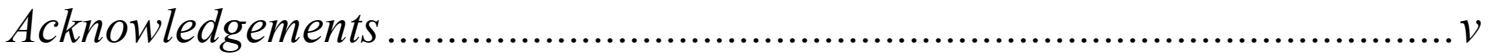

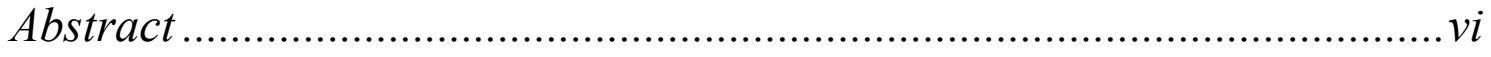

Chapter 1: Defining Fundamentalism ..................................................... 1

Chapter 2: Compassion Between Strangers ...............................................32

Chapter 3: Rehabilitation in a Familial Home .........................................60

Chapter 4: Courage in the Social Sphere …...........................................80

Chapter 5: Invitation and Community ..................................................102

Chapter 6: Fundamentalism: Final Words and Future Implications .......123

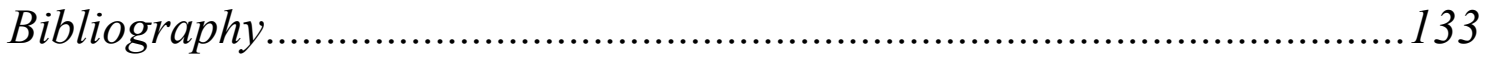




\section{Preface}

The excerpts from biblical narratives are quoted from the $E S V^{\circledR}$ Bible (The Holy Bible, English Standard Version ${ }^{\circledR}$ ), copyright 2001 by Crossway Bibles, a publishing ministry of Good News Publishers. Used by permission. All rights reserved. 


\section{Acknowledgements}

This project is different than I imagined, more than I anticipated, and many people have had a hand in the making of this work. Though words are often inadequate I offer these of gratitude. I am thankful for my committee, Patricia Sotirin, Stephen Pluháček, Ramsey Eric Ramsey, and Robert Johnson. My project is a reflection of the ways that you have taught me to engage critically and thoughtfully with scholarship and with the world. I am honored to have been granted the opportunity to learn with you. I am also thankful for the first year students in my fall section of UN1001 at Michigan Tech. Thank you for the chance to consider my project from a pedagogical perspective, thank you for the conversations and the in-class discussions that helped me think differently and better. Thank you Dr. Richard Fellars for teaching me to honestly question and seriously engage with scripture. Finally, Matt, my partner and my friend, thank you. 


\section{Abstract}

This project examines fundamentalism understood as an everyday way of living poorly with difference. It demonstrates that the fundamentalist is not reducible to stereotypes of the terrorist, extremist, irrational madman, or religious zealot. All of these characterizations - common in mainstream media - depict the fundamentalist as them, and rarely, if ever, as $u s$. Rather, this project understands fundamentalism in terms of fundamental interpretive constructs that constrain our ways of being-with others, skew our interpretive and responsive possibilities, distort our perceptions of difference, and affirm our poor treatment of others. Following Martin Heidegger's conception of the hermeneutic structure of existence, this dissertation calls attention to the ways in which such fundamentalisms filter our interpretation. Yet the hermeneutic character of existence also highlights the incompleteness of any particular frame of interpretation and indicates the possibility of alternative interpretive responses. The project turns to a feminist theological hermeneutic in order to indicate more hopeful and liberating ways of living with difference, ways that point beyond everyday fundamentalism toward invitational communication.

Through new readings of familiar biblical narratives, this dissertation revisits the fundamentalisms that trigger these narratives in order to draw out an alternative feminist theological hermeneutic, or what is termed here an invitational hermeneutic. Each story offers unique ways of making sense of being-with and sharing the world with others of difference that redress the impoverished and fundamentalist forms of self-preserving care and understanding. By examining the well-loved stories of the Good Samaritan, Ruth and Naomi, Queen Esther, and the Apostle Paul and Lydia, the dissertation identifies interpretive and responsive possibilities that together issue an alternative hermeneutical invitation: to understand difference compassionately, to engage strangers and family members alike with rehabilitative care and concernful reticence, and to extend graceful hospitality to others. In these ways, the dissertation indicates 
possibilities beyond the horizon of fundamentalism, invitational possibilities of living and communicating with difference. 


\section{Chapter 1: Defining Fundamentalism}

The term fundamentalism first entered into religious discourse in the early $20^{\text {th }}$ century as a welcome label of distinction applied to conservative American Protestants who found themselves in agreement and willing to wage "battle royal for the fundamentals of Christian doctrine." ${ }^{1}$ The fundamentals to which these followers ascribed had been neatly outlined in 1920 within a series of widely distributed pamphlets entitled The Fundamentals: A Testimony of Truth. These tracts were written for the express purpose of exposing, addressing, and combating the erosion of the fundamental beliefs of Protestant Christianity and the increasingly liberal interpretation of scripture being accepted by American congregants. Despite these American Protestant roots, fundamentalism both in language and practice far exceeds its semantic origins. The term fundamentalism has been applied to a wide range of 'believing' or religious communities and as Malise Ruthven has suggested, generally describes "a religious way of being that manifests itself in a strategy by which beleaguered believers attempt to preserve their distinctive identities as individuals or groups in the face of modernity or secularization." In addition to this fitting description Justin Clemens has investigated fundamentalism at the individual level and suggests that the fundamentalist, by strict adherence to belief systems that posit others as "good or evil," makes bad distinctions between self and other resulting in the need to stop the evil other. Further still, Adam Phillips has taken fundamentalism out of its typically religious constraints and has proposed that, "we are all fundamentalists about something." ${ }^{3}$ Phillips' allencompassing fundamentalism is possible because on his telling, "the fundamental things are the things that upset us; and even though we think of our civility as constituted by our fundamental beliefs, our civility and our fundamental beliefs are easily at odds with one another." Ruthven points to the past and tells of a deeply religious and doctrinally obsessed fundamentalist. Clemens makes way for what I will later describe as the "us versus them" trouble with fundamentalism. And Phillips' 
version of fundamentalism moves away from religion altogether while holding on to the notion of conviction or belief and suggests that fundamentalism is a matter of how we all deal with what is fundamental to us and not who the fundamentalist might be. These definitions help to articulate the origins of the fundamentalist phenomena and also provide a baseline from which a broad understanding will be conceived.

Popular conceptions of the fundamentalist describe a person who invades, who is aggressive, menacing and ruthless. According to some, fundamentalists are people who find themselves in a "special category," a group whose members are "partcriminal, part-psychopathic." The fundamentalist is no longer simply one who adheres to strict doctrine for the purposes of purity within his or her community; the contemporary fundamentalist must be feared because they are not sane, they are not normal, they are not the same as everyone else. In the face of the fundamentalist threat, Nigerian writer and human rights advocate Wole Soyinka has warned those of us who are not fundamentalists to be on alert because "the world is facing viral mutations of the human psyche." ${ }^{\prime 6}$ Soyinka affirms our fears by describing the fundamentalist as one without sense, the insane criminal — who could be anyone except me. His words are telling: "The truth, alas, is that the archetype of the mad scientist who craves to dominate the world has been replaced by the mad cleric who can only conceive of the world in his own image, flaunting James Bond's 007 credentials - licensed to kill.,"7 Soyinka calls national and religious leaders to "admit that no nation lacks its own dangerous lunatics." The traditional definition of the fundamentalist has been transformed and now describes the violent and mentally insane - the fundamentalist is in a special category of criminal who must be stopped at all costs. We who are not fundamentalists, like Soyinka, work hard at protecting ourselves from these violent madmen. In a similar way, Clemens reminds those who are 'not' fundamentalists of the uncritical way in which we too make poor distinctions between self and other as the fundamentalist gets labeled as the they who must be stopped. ${ }^{8}$ Thus, fundamentalists are not the only ones who make sharp distinctions between themselves and others or ruthlessly protect themselves from strangers. 
Here we catch sight of two important characteristics. First, fundamentalisms are many. The "fundamentalist" does not fit a cookie cutter definition and her practices of care for others are as varied as her fundamental concerns. Poor distinctions between self and other occur on a number of relational levels and are expressed along a continuum of both thought and deed. Second, fundamentalism has been and still is the practice of setting up boundaries where sameness is protected and where difference, though sometimes tolerated, is often neutralized. Fundamentalists set up communities of sameness. They "work hard to build parallel world[s], away from the mainstream, with their own schools, universities, media," and these parallel worlds foster a strong sense of community. ${ }^{9}$ Communities of sameness thus serve to shelter the fundamentalist from outsiders. Members are kept secure from as well as educated against mixing with influences that might threaten the values and accepted practices of the social sphere. Fundamentalisms affirm the erection of rigid borderlines in order to confirm assimilation and ward off unwelcome intrusion by people of difference.

An illustration of the fundamentalism I describe can be found in the popular children's story Charlotte's Web. In the story Charlotte, a grey spider, weaves fantastic words into her web. The words are descriptions of her friend Wilbur, a young runty spring pig, and are intended to save his life from the yearly Christmastime butchering that is the fate of all the pigs on Mr. Zuckerman's farm. Charlotte's plan works, Wilbur's life is spared, and along the way we learn a little about what it might mean to befriend others of difference. Each of the barnyard animals plays a part in the elaborate plan to save Wilbur, but none of them would have chosen to do so without Charlotte. As it happens Wilbur is the first pig to be rescued and the last pig to be raised for the butcher block. ${ }^{10}$

Charlotte's Web is a simple children's story, but if allowed, it is a story that leads us to an understanding of the difficulty we too find in sharing our worlds with others of difference. In the early moments of the story the animals are found selfishly going about their daily business with little or no concern for the others in the barn. The lamb does not wish to be Wilbur's friend because "pigs mean less than nothing" to 
her. ${ }^{11}$ The Goose along with everybody else is concerned that Templeton the rat will harm her goslings because the rat had "no kindness, no compunctions, no higher feelings, no anything." And even Wilbur is concerned that Charlotte is "fierce, brutal, scheming, bloodthirsty — everything he do[esn't] like." ${ }^{13}$ In the beginning these barnyard animals prefer to make friends with animals of the same species and are hesitant, even judgmental, regarding others of difference. The animals depict an impoverished and fundamentalist way of being with others of difference in the world. In this project I will examine various relational expressions of fundamentalisms which represent a widespread cultural phenomenon that affirms the poor treatment of others as well as primary ways of being-in-the-world in which difference is distorted.

With Charlotte's help the animals learn to embrace difference and their differences become the catalyst for a community that works together to save a life. As the animals join forces in spirit and practice to spare Wilbur, unexpected kindness emerges as one of the possibilities of being together on the farm-even from the least likeable of characters. At the end of the story we find this passage describing the atmosphere in the barn:

Life in the barn was very good - night and day, winter and summer, spring and fall, dull days and bright days. It was the best place to be thought Wilbur, this warm delicious cellar, with the garrulous geese, the changing seasons, the heat of the sun, the passage of swallows, the nearness of rats, the sameness of sheep, the love of spiders, the smell of manure, and the glory of everything. ${ }^{14}$

The glory Wilbur revels in is the nearness of difference, the wonder of the other. It was the best place to be. The hopeful paradox of our varied fundamentalisms is found in these simple words uttered by a fictional pig. Though constrained by fundamentalisms that distort our understanding and our practices of caring for others, we need not despair. There are alternative possibilities for sharing the world. 
In the chapters that follow I will examine four biblical narratives in order to demonstrate fundamentalism as a basic structure of being in and sharing the world with others of difference. Traditional and popular conceptions of fundamentalism do not and cannot account for the way the phenomenon has rapidly extended beyond its origins of practice. Nor do these surface level descriptions consider the varied differences of the people with whom the world is shared. Additionally, though these descriptions offer a telling picture of fundamentalist practices, they do not offer alternative ways of sharing the world with others of difference. In other words, contemporary conceptions of fundamentalisms provide a diagnosis of a problem - a problem that I will demonstrate is human, is pervasive, and is not partial to denominational concerns - but absent from these diagnoses is a prescriptive salve wherein relief might be understood. While traditional conceptions certainly describe common characteristics of a contemporary struggle whereby extreme manifestations of the phenomenon can be explained, fundamentalisms are much more.

Fundamentalism is a mindset, an unexamined system of belief that filters our perceptions, ${ }^{15}$ and allows us to categorize others based on their differences while remaining ignorant of our difference. Elizabeth Spelman offers a rich description much like the fundamentalisms I intend to elucidate, suggesting that, "[g]iven the history of Western feminist theory, it is not white middle-class women who are different from other women, but all other women who are different from them." ${ }^{, 16}$ In this short statement white middle-class feminist theorists are called to account for the ways they have set up communities of sameness where difference is a matter of being estranged from the unchallenged dominant version of womanhood. We need the other because they are not like us and we are not like them-fundamentalism promotes sameness at the expense of difference. Fundamentalism is a mindset that causes us to pass over and around an other because they do not count, they cannot count.

I propose that contrary to popular and traditional definitions, fundamentalism is not a denominational but a human inclination. It is a manner of life and practice wherein we find ourselves disparaging difference, seemingly unable to perceive the other as 
worthy of compassionate care. Fundamentalism is a problem to do with us and them-it is human and it is pervasive. Fundamentalisms encourage us to pass by or around difference and in so doing we poorly attend to the others with whom we share the world. This poor attendance is reflected across relational contexts.

My project does not end with an elaboration of the fundamentalist problem. Upon examining fundamentalisms as hermeneutics that shape our understanding of the world, I then turn to alternative hermeneutics, modifications I describe as feminist and theological that invite us to consider hopeful and liberating ways of being-with others. I suggest a feminist modification because liberating, respecting, and listening to difference is both the provocation and the paradox of feminist concern. ${ }^{17}$ The theological component of the alternative hermeneutic that I propose is grounded in the notion that to care for another is to have met and cared for the divine. ${ }^{18}$ I agree with Adriaan Peperzak who points to faith filled with wonder found in turning toward the others with whom we share the world. He writes: "The Good is not to be found on the summit of an ideal hierarchy, but rather in the lowlands of compassion with ordinary humans. But this compassion cannot be separated from the practice of transcendence." ${ }^{\prime 19}$ In the rough ground of compassion we experience what I call an invitation that is a sacred opening thanks to the corporeal appearance of difference between ourselves and the other. This opening, this invitation that is the shared presence of difference, asks us to go again and again and dwell together in the world. Fundamentalisms are ways of being-with and caring poorly for others of difference. A feminist modification attends to our skewed fundamentalist perspective of difference, and a theological modification unveils an invitational impulse for our everyday practices of care.

\section{Heidegger on Fundamentalism: Hermeneutics, Care, and the They-Self}

In order to demonstrate that fundamentalisms are pervasive human inclinations in which we interpret and respond poorly to difference, it is necessary to address the interpretive nature of our everyday existence. In this section I will examine the hermeneutic structure of being-in-the-world and fundamentalist tendencies in our common practices 
of being-with others of difference. This initial examination is indebted to key concepts developed by Martin Heidegger in Being and Time and is foundational for this project both for the articulation of fundamentalisms and for imagining alternative ways of responding to others. ${ }^{20}$

Heidegger leads us to the understanding that existence is a matter of making meaning, that is to say interpretation. But interpretation is not an easy task because interpretive possibilities are presented to us within specific contextual constraints. Said differently, we understand things as they are within the framework that has been given to us. This framework often goes unnoticed or is taken for granted. For example, one of the interpretive givens is tradition. Heidegger writes:

Dasein is inclined to fall back upon its world (the world in which it is) and to interpret itself in terms of that world by its reflected light. [...] Dasein simultaneously falls prey to the tradition of which it has more or less explicitly taken hold. This tradition keeps it from providing its own guidance, whether in inquiring or in choosing. [...] When tradition thus becomes master, it does so in such a way that what it 'transmits' is made so inaccessible, proximally and for the most part, that it rather becomes concealed. Tradition takes what has come down to us and delivers it over to self-evidence; it blocks our access to those primordial 'sources' from which the categories and concepts handed down to us have been in part quite genuinely drawn. ${ }^{21}$

We are often unaware of the ways our understanding has been shaped by the tradition(s) of the world. Nevertheless, we cannot escape these traditions. What we understand, or what we think we have understood, is partial. In one sense our understanding is limited and contextual due to the interpretive constraints of tradition and in another sense we are partial to and biased against specific interpretations of things and others. What we 
see is limited and we limit what we see. Said differently, interpretation is perspectival, it is always incomplete.

Existence is hermeneutic, that is, by nature we try to make sense of things. But our sense-making or interpretive capacities are partial and we often efficiently arrive at conclusions based on long-concealed traditional renderings and hidden biases. These hidden biases include the varied fundamentalisms through which we perceive and respond to others. Heidegger refers to these hidden interpretive constructs as forestructures, writing: "When something is understood but is still veiled, it becomes unveiled by an act of appropriation, and this is always done under the guidance of a point of view, which fixes that with regard to which what is understood is to be interpreted." ${ }^{, 22}$ Being-in-the-world is always a matter of attending to and interpreting ourselves, others, and objects. What we understand about ourselves and others is, by virtue of our hermeneutic existence, only ever part of the story.

Beyond the larger and oft concealed fore-structures that guide our understanding such as tradition, we also find ourselves having moods or being in states-of-mind which further filter our possibilities of response. Heidegger helps us realize that " $[i] t$ is precisely when we see the 'world' unsteadily and fitfully in accordance with our moods that [what is in the world] shows itself in its specific worldhood, which is never the same from day to day. ${ }^{, 23}$ How we feel, whether we are in a bad, happy, fearful, or content state-of-mind grants particular responses for specific situations. We see, hear, and speak differently depending on the mood in which we find ourselves. For example, to have awakened on the "wrong side of the bed" or to find oneself feeling refreshed and lighthearted from the start, significantly affects our interactions throughout the day. It affects how we respond to things that break, people who disappoint, or unexpected interruptions of our time. That is, our moods filter our possibilities of response. Understanding is always limited by the fore-structures and moods that help us make sense of the world.

What I have illustrated in this brief discussion of Heidegger's conception of the hermeneutic structure of existence is that we are meaning-making and interpretive; our 
interpretations are guided by concealed fore-structures or mindsets and the changing nature of our moods; and, these interpretations are necessarily partial. By recognizing this hermeneutic structure we come to the understanding that fundamentalisms offer interpretive possibilities for being-with others in the world by providing readymade answers to the questions that arise in our everyday encounters with people of difference. Fundamentalisms are hermeneutics that misinterpret difference by making either too much or too little of difference. Instead of respectful response, fundamentalisms quickly answer the other based on hidden interpretive constructs that neutralize difference. Fundamentalisms filter our capacities of response to difference.

In attempting to uncover who we are, Heidegger not only calls attention to the hermeneutic structure of existence, but he helps us see that we are always with - that is, we always find ourselves in the world with others and objects. Aloneness is predicated upon the absence of others. ${ }^{24}$ As Heidegger writes, "the world is always the one that I share with Others. The world of Dasein is a with-world [Mitwelt]. Being-in is Beingwith Others." ${ }^{25}$ This being-with is carried out through varying degrees and practices of care toward the others (which Heidegger refers to as "solicitude") and through concern with the objects within the world. We are always in the world with others and are granted, as part of being-with, opportunities to care. Heidegger helps us see that others are always a part of existence. From this understanding of existence as being-with Heidegger then elaborates both the positive and the deficient ways we come to care for others:

Being for, against, or without one another, passing one another by, not 'mattering' to one another-these are possible ways of solicitude [care]. And it is precisely these last-named deficient and indifferent modes that characterize everyday, average Being-with-one-another. [...] With regard to its positive modes, solicitude has two extreme possibilities. It can, as it were, take away 'care' from the Other and put itself in his position in concern: it can leap in for him. This kind of solicitude takes 
over for the Other that with which he is to concern himself [...]. In such solicitude the Other can become one who is dominated and dependent, even if this domination is a tacit one and remains hidden from him [...]. In contrast to this, there is also the possibility of a kind of solicitude which does not so much leap in for the Other as leap ahead of him [...] not in order to take away his 'care' but rather to give it back to him authentically as such for the first time [...]. Everyday Being-with-oneanother maintains itself between the two extremes of positive solicitude - that which leaps in and dominates, and that which leaps forth and liberates. ${ }^{26}$

Heidegger teaches us that care is the way that we are with one another, and as a practice care is not limited to positive manners of attending to each other. Care is the way in which others come to "matter" to us. Deficient care is marked by actions such as passing over or around another - the other is not deemed worthy of respectful response. In deficient care we are indifferent to the other. Our ways of being-with that other are, at best, impoverished. This brand of negative or indifferent care for the other is precisely the manner of being-with encouraged by the fundamentalisms that filter our responsive inclinations. How others come to matter to us, and how we care- these are the ways of being-with where fundamentalisms are most clearly observed. Said differently, fundamentalisms, which affirm deficient forms of care, are exhibited in various relational contexts.

But deficiency is not the only mode of care. There are positive modes of beingwith others. These positive modes are found in the ways that we, upon encountering an other, attend to him or her with attention for their own sake - in order that they might better care for themselves in the world. Others matter to us and our care helps bring them back to their senses - for their good. Heidegger does not spend much time elaborating the positive characteristics of care. He does affirm, however, that both "leaping in" and "leaping ahead" are possible. Thus his work on care, or solicitude, 
provides an opening that I will explore further in order to consider ways to counterbalance fundamentalist hermeneutics.

Now that I have connected Heidegger's conception of care to fundamentalist practices it is necessary to attend to the claim that fundamentalist hermeneutics are common structural interpretive possibilities for being-with others. Fundamentalisms order every being-with others. Being-with lumps us together in what Heidegger calls the public they, or they-self [das Man]. The they is a way of care that has been determined by accepted and banal responsive possibilities often exhibited in popular and poor expressions of being-with others. The they is a common, public interpretive forestructure that constrains care and justifies exaggerated and ignorant responses to difference. It is crucial to understand that the they does not simply refer to practices of treating others poorly but is how, who, and where we are in the world with others. As members of the they we are, and legitimately so, indifferent to difference, comforted in the imagined sense of the sameness of the community, enamored by an average acceptance of the ideas and pursuits of everyone, engrossed in competition, and ruthless in our affirmation of tradition, culture, and progress.

The they is the condition for the possibility of impoverished care. As members of the they we relate to one another in comparison and competition. Others, and we, are measured based on the popular value of our external particularities or what we "bring to the table." In this first aspect of the they we evaluate ourselves against the perceived success of an indiscriminate Other. But this comparison merely places each one in subjection to the Others who use and take from each according to the whims of the indistinct group. In this way the particularity of each is "dissolved" such that responsive possibilities like enjoyment, awe, disgust, or compassion are dictated by the average concerns of the they. Heidegger suggests that this way of averageness discloses an essential tendency of human nature, a tendency that he has called leveling down. ${ }^{27}$ Leveling down is the nature of our everyday experience in the they. Having been assimilated within the they we find ourselves at a loss for respectful sensitivity to difference of any kind. Heidegger describes the nature of the they as a public and 
prescriptive state-of-mind in and out of which we have grown accustomed to being-with and interpreting others:

Publicness proximally controls every way in which the world and Dasein get interpreted, and it is always right - not because there is some distinctive and primary relationship-of-Being in which it is related to 'Things', or because it avails itself of some transparency on the part of Dasein which it has explicitly appropriated, but because it is insensitive to every difference of level and of genuineness and thus never gets to the 'heart of the matter'. [...] This everyday way in which things have been interpreted is one into which Dasein has grown in the first instance, with never a possibility of extrication. In it, out of it, and against it, all genuine understanding, interpreting, and communicating, all rediscovering and appropriating anew, are performed. [...] The dominance of the public way in which things have been interpreted has already been decisive even for the possibilities of having a mood - that is, for the basic way in which Dasein lets the world 'matter' to it. The 'they' prescribes one's state-of-mind, and determines what and how one 'sees'. 28

Things are leveled down such that all are treated with a superficial inquiry that perpetuates sameness and filters response through a framework of averageness. The everyday way of being in the they serves to guide our interpretive possibilities. How we make sense of things is determined by what is deemed acceptable within the public and average interpretive capacities of the they. In the absence of genuine response, we have misplaced any sense of responsibility such that at the same time everyone and no one can be made accountable. As Heidegger writes: “In Dasein's everydayness the agency through which most things come about is one of which we must say that 'it was no one'." 29 Heidegger's analysis of our everyday being-with others and objects in the 
world points us again to the realization that our possibilities of interpretation and response are always situated, particular, and necessarily limited. Existence is hermeneutic and our understanding is veiled. Heidegger proposes that interpretation is thus something that begins long before we are called to draw conclusions or make decisions regarding others and objects. ${ }^{30}$

Fundamentalisms represent the everyday expressions of the they which affirm distorted interpretation and response to others of difference. While I certainly intend to consider fundamentalist manners of being-in-the-world with others, it is crucial to understand that fundamentalisms are not just poor practices of care. Fundamentalisms not only distort our interpretation of difference but significantly, that the distortion is how and who we are in the world. Fundamentalisms level down difference and habituate our responses such that we attend poorly to others in our world. It is on the basis of this understanding of everyday fundamentalisms that we come to realize alternative possibilities of response for and with others. Alternative ways of sharing the world have been granted to us within the fundamentalisms that structure Being. Alternative ways are thus evident and possible only as modifications of the fundamentalist hermeneutic in which we always already reside.

Fundamentalisms constrain our possibilities of responsive care for others. Heidegger helps us see that fundamentalist hermeneutics are not the only ways of being-with and understanding others. ${ }^{31}$ The hermeneutic structure of our existence is the condition for the possibility of other ways of being-with. Fundamentalisms may be the common, everyday, impoverished ways of being-with others, out of which our responsive tendencies have already been trained, but they are not the only way. Additionally, as hermeneutics, fundamentalisms do not represent something to be overcome, but rather something to be lived with and struggled against. The problem is not just that others matter and are thus treated with varying degrees of care-but that fundamentalist hermeneutics filter our responsive possibilities such that external difference(s) become the basis for the ways that we and others matter and thus respond to each other. Here we come to the heart of this project; namely, to uncover 
fundamentalist inclinations as well as alternative hermeneutic possibilities for sharing the world. In what follows I will briefly address the specific feminist and theological aspects of the proposed alternative hermeneutic.

\section{A Feminist Theological Hermeneutic}

The hermeneutic I propose is feminist insofar as it encourages a purposeful attention to the multiple subjectivities and layered identities of the women and men whose stories are pivotal to the work of revealing the fundamentalist mindset. It is feminist in that women and women's stories, as well as feminine and feminized subjects, serve as the focus for interpretation. Additionally, the themes in the stories I will analyze are themes traditionally associated with women and feminine subjects: familial relations, social relations, procuring food, caring for bodies, caring for house and home, the exclusion or invisibility of women, participation in or exclusion from decision-making processes, agency, and women's spiritual and material flourishing. These stories reveal a feminist hermeneutic that teaches us to account for difference in ways that have been concealed by fundamentalisms.

This hermeneutic is indebted to the work of Luce Irigaray. Difference, specifically sexuate difference, is the primary focus of Irigaray's thought. As such, her work offers a unique feminist interpretation and response to the dominant pattern of understanding the world and the others with whom we share it- the mindset that I have called fundamentalist. In a critical mode, Irigaray describes a world of imagined sameness fabricated and sustained by the false notion of a singular subjectivity; a world of people who have for centuries considered only a male and therefore an incomplete understanding. This flawed, incomplete, and male-dominated world refuses to acknowledge the other whose sexuate difference necessitates another, feminine subjectivity. I use the term sexuate difference in ways similar to Irigaray in order to first distinguish it from sexual difference, which conveys sexual orientation and the social construction of sexed roles. As Heidi Bostic writes of the term sexuate difference in Irigaray, it "represents a way of trying to think sex/self without necessarily referring to 
sex/act." ${ }^{32}$ Sexuate difference refers to difference that is a basic, ontological structure of who we are, a difference that necessitates dual subjectivities and worlds. Sexuate difference is the difference that requires a world of two rather than the false but commonly imagined and widely accepted version of one. By recognizing the otherness of the feminine subjectivity, we find a way of being-with in the world that is founded upon difference, that recognizes the multiplicity and partiality of worlds. Describing the male-created world, Irigaray writes: "The world, or worlds, that he constructs will close over him so tightly that reaching something outside him becomes difficult for him. $\mathrm{He}$ does not even remember the fact that his body is the threshold, the portal for the construction of his universe, or universes. ${ }^{33}$ In this passage we find Irigaray discussing the manmade world in terms that recall Heidegger. The man she portrays is suffocating. His world has restrained him. He cannot imagine, let alone reach outside of the bonds of his own making. And he does not entertain any notion of another whose difference would surely rupture the dominant but flawed understanding of his world. His world is incomplete - and he does not desire that it be otherwise.

The consequences of this incomplete world are significant. This man's world is the forestructure wherein we, both women and men, have come to make sense of things and others with whom we reside. On Irigaray's telling, this partial world not only separates us from others of difference, but also, perhaps more importantly, makes us lose, or rather forget, a part of ourselves. We cannot hear. We do not see. Our breath is constricted. Our words are rehearsed. We have lost ourselves. The world of man's making is a place of mastery, production, and exchange.

Irigaray elucidates and rejects a world of one. In so doing, she uncovers the markers of a fundamentalist hermeneutic of possession and power, where others are treated as objects to be managed and discarded; of passivity, where out of willful blindness we choose to pass over or around others of difference whose very presence alerts us to their need; and of senselessness and assimilation, where we, having been so long in the tight enclosure of our world, have forgotten ourselves and our bodies. Fundamentalisms seek to replicate poor versions of an imaginary sameness based on a 
flawed, one-sided perception of a fabricated world. Moving beyond this imagined sameness bound by a false sense of a singular masculine subjectivity, Irigaray then ushers us on to other possibilities. We are two and we can imagine and even struggle "little by little" to make way for a world of two. Though we are not there yet, Irigaray suggests that " $[\mathrm{m}]$ anaging to respect the other of sexual difference, without reducing the two to the one, to the same, to the similar $[\ldots]$ represents a universal way for attaining the respect of other differences. ${ }^{34}$ Because we are two, we are different. From this primary difference Irigaray begins to elaborate a world not yet inhabited - a world where others and all differences can be attended to with understanding and respect.

Given that Irigaray's feminist philosophy of difference is central to the alternative hermeneutic I have developed I must address my appropriation of her work. In calling attention to the reality of two subjectivities, languages, and worlds, I am in no way putting forward an essentialist conception of gender. Gender is not the only significant difference and as Spelman rightly suggests, "what it means to be a 'woman' depends on what else is true about oneself and the world in which one lives." ${ }^{, 35}$ While I intend to demonstrate fundamentalisms as basic trans-historical structures of being-inthe-world, it is crucial to be aware that practices or behaviors associated with a fundamentalist hermeneutics may not be and often are not the same for all peoples and across all cultures. That is to say, the subjection felt and accepted as part of the fundamentalist mindset cannot be separated from particular social, cultural, and historical contexts. I thus turn to Irigaray not to presume a definition of and for all women and men but rather to suggest that fundamentalism is a problem to do with sameness first articulated within a masculine imaginary. We cannot get beyond the oppressive foreground of sameness without starting anew with the realization that at a minimum the world is shared by two. Once again Spelman is helpful. She writes:

If the meaning of what we apparently have in common (being women) depends in some ways on the meaning of what we don't have in common (for example our different racial or class identities), then far from 
distracting us from issues of gender, attention to race and class in fact helps us to understand gender. In this sense it is only if we pay attention to how we differ that we come to an understanding of what we have in common. $^{36}$

We must admit that other differences such as race and class allow important interpretive possibilities both within and beyond sex. That said, in this project sexual difference is the grounding distinction that opens up understanding of the multiplicity of difference that resides in the other, the other who is not and could not possibly be like me. But this is not to say that sex is the only difference that might offer alternative vantage points of otherness. In sexual difference we witness the other and in their presence we respond. Sexual difference is a site of both fundamentalism and compassion, and from this site we will encounter possibilities for what it might mean to be with others in the world. The narratives that will be examined within the chapters of this text portray women and men: some who have been captured by a mindset that diminishes others of difference and some whose difference is the catalyst for treating others well.

This hermeneutic is distinctly feminist as it pays heed to the contextually situated nature of the narratives studied, their characters, and our interpretation of each. Not only is this project an effort to rethink and retrieve four biblical narratives from the clutches of fundamentalist interpretation, it is also an attempt to bring us to acknowledge that "how we see things is profoundly affected by where we stand as we look." 37 The re-telling or new imaginative lens through which the stories are told is admittedly feminist as each encourages a particular and localized reading of the accounts of the lives of women and men. A feminine praxis of being-with in the world offers, in each narrative, alternative possibilities of caring for others. The stories perform the task of revealing another way of dwelling with difference. Here, Serene Jones is helpful. She writes: 
It is crucial that we continue to value the place of 'stories' in our understanding of women's diverse lives; as a procedural strategy, narrative seems to travel well across cultural divides. Telling stories allows us to hold together an appreciation for difference and indeterminacy (effective storytelling requires an element of the unexpected) with a desire for coherence and temporal order (narratives, after all, seem to require at least a modicum of both). ${ }^{38}$

Stories travel, they cross borders, they are constricted only by those unwilling to listen. The feminist hermeneutic I put forward is cognizant of the crucial role narratives can play in fostering either debilitating or liberating ways of making sense of the world. This hermeneutic listens to stories because stories are how we inhabit the world. We need this feminist consideration of narrative in order to widen our visionary horizon beyond the common fundamentalist reduction to average stories of the they-self.

Finally, within this feminist hermeneutic we are called to care for and work toward the mutual flourishing of all —all those with whom we share the world. Flourishing, blossoming, becoming - these are the words Irigaray often employs to describe both the reason for and the manner of life possible when worlds are shared. ${ }^{39}$ In this endeavor, Irigaray is not alone. Human flourishing is a primary goal of much feminist theory and practice. In other words, feminist theory not only interrogates systems of oppression, but does so for the purpose of the "ultimate flourishing of women." ${ }^{, 40}$ Along these lines Grace Jantzen highlights the hopeful possibility of a feminist theological model of flourishing. Flourishing teaches us that things of life must grow and that growth is a cyclical life process. ${ }^{41}$ Flourishing requires a community of care. It is not simply an individual chore. Calling attention to Hannah Arendt's desire to practice love for the world (amor mundi), Jantzen likens flourishing to the 'fostering of life,' and elaborates it as "acting in such a way as to try and ensure that newcomers will not be worldless, that their uniqueness is valued so that they need not lose themselves in the masses. ${ }^{, 42}$ Flourishing requires that we care for the immediate material conditions 
of people's lives. ${ }^{43}$ Flourishing is the impetus behind and the mindset of care at work in the feminist hermeneutic I propose. It is a hermeneutic wherein others must be well cared for. It is a hermeneutic marked by invitational tending care. It is a hermeneutic where the material conditions of life are not an afterthought to those outside the perceived circle of immediate concern because all are within the community of care, and all are encouraged to turn toward those in need.

Given the feminist influences that shape this project it is crucial to consider how care will be addressed in ways different from those whose work is often referred to as feminist ethics of care . Daryl Koehn has provided a shortlist of definitional characteristics associated with the feminist ethics of care first described by Carol Gilligan $^{44}$ and Nel Noddings. ${ }^{45}$ As a feminist ethic, care is understood as "active, interpersonal, mutual reciprocity." 46 It is a concern evidenced in constant interpersonal striving to meet the physical and emotional needs of others. Caring is thus a positive practice that suggests attunement to the feelings of another. Caring is about listening and suspending judgment. The one who cares becomes totally "engrossed" $" 47$ in another person such that the self is and can be shared with the other.

These characteristics of care help to articulate vital differences between care as it will be understood in this project and feminist ethics of care. First, in this project care takes many forms and is reflected in both positive and deficient practices of being-with. Care is how we are with others in the world: sometimes we do it well and sometimes we do it poorly. This understanding of care is quite different from a feminist ethic of care, where care and caring are only positive forms of tending to the needs of others. A second crucial distinction is found in the notion of being engrossed in and sharing the self with another. We have already come to the realization that existence is always with. We share the world with others. Later in this chapter we will uncover the nature of this shared world as inherently different and plural. The world, or rather worlds we inhabit are different; part of the fundamentalist problem has to do with how we come to share these worlds of difference. This project elaborates a version of care where worlds, not selves, are shared in the spaces and pathways between people of difference. I do not 
advocate total engrossment in the life of another or the sharing of the self. The positive forms of care that I advance look much like Heidegger's leaping ahead, where upon finding another in need we care for them best by bringing or returning them to themselves and their own senses, helping them to find the wherewithal to share their world with others of difference. The care that I propose does more than providing a list of positive forms of caring whereby the needs of others can be assessed, listened to, and addressed. I understand care to be the practice of helping the other see things differently; to become aware of who she is and who she might become.

In addition to these important differences, there are some noteworthy similarities between feminist ethics of care and the feminist theological hermeneutic that I propose. Feminist ethics of care begins from an understanding that we are social and relational beings who live in a world where power and oppression have silenced the voices of the most vulnerable. ${ }^{48} \mathrm{~A}$ feminist ethics of care also values the differences and the distinct and varied "histories and interests" of others. ${ }^{49}$ Feminist ethics of care is grounded in the notion that change is possible in the world - that we need not be confined to oppressive ways of being with others - that caring in positive ways for people of difference is possible. In other words, "[w]e make the world in which we act, sense and love through our actions. $" 50$ The hermeneutic that I will address in greater detail later in this chapter and within subsequent chapters finds resonance with these tenets of feminist care ethics. We are social and relational, always finding ourselves with others in the world. Importantly, fundamentalisms often stifle and ignore the voices and varied differences of others. Finally, the alternative invitational feminist theological hermeneutic that I describe is a modification of our fundamentalist hermeneutics that opens up new responsive possibilities for being-with others.

\section{A Feminist Theological Hermeneutic}

The hermeneutic I propose is not only feminist but also theological. The presence of others wrests us from routine and calls us to response. The appearance of an other is a invitation that holds the possibility of modifying fundamentalist hermeneutics and 
awakening us to alternative ways of response and care. This hermeneutic is based upon a Christian theology of invitation and hospitality which is reflected in the words of John, the disciple of Jesus: "Behold, I stand at the door and knock. If anyone hears my voice and opens the door, I will come in to him and sup with him and he with me."51 The coming of the other is an opening, an invitation between people of difference that harbors multiple responsive choices.

A feminist theological hermeneutic welcomes the invitation of an other as the space where difference is perceived and understood as vital for the mutual flourishing of the world(s) we share. And, difference from a theological perspective is not merely an external marker of otherness but a revelation of a divine mystery harbored in the bodily appearance of the other. Peperzak, hearkening to the important work of Emmanuel Levinas, writes: "I, the subject whom the Other obligates, am steeped in the economy of a world that we share [...], but the face-to-face shows that you — but also I as facing and speaking to you - are rooted in another dimension than the worldly one. ${ }^{, 52}$ The difference of the other is an invitation that affords us the opportunity to care well. Thus difference is the corporeal manifestation of an invitation to another world, a world other than mine, a world of which I have been unaware. This theological hermeneutic perceives the presence of difference as invitations of the divine and calls us to our senses infusing the mundane with the sacred.

This invitational hermeneutic is grounded in Irigaray's conception of sexuate difference. Once difference is attended to, once we accept the twoness of the world, we can begin to construct pathways, inroads, bridges toward the other and back to ourselves. And our encounter is the site of a radical, sensual transcendence- it is the place where we come to our senses. Where we are granted the vision to behold the alterity, to hear the music of the other, to touch, to embrace the difference that had been or rather has been hidden. This new world and language and the pathways between must be made. We must build. We must, as Irigaray proposes, "construct a world in all its and their dimensions. A universe, not merely for the other, as [we] have been asked to do in the past: as keepers of home and children, mothers, in the name of the property, 
the laws, the rights, and obligations of the other's State. A world for women." ${ }^{, 53}$ The construction of such a world for the feminine would necessitate a reconstruction of the masculine so that what is shared in the space between is new. The in-between is a place where difference is encountered - it is a place where, if we are willing, we come to experience the "celestial [that] lies not only above our head but also between us." ${ }^{54} \mathrm{We}$ come to understand that being-with is not a matter of leaving the world(s) we inhabit in order to access a divinity that removes us from the present, from ourselves. Rather, being-with begins by remaining faithful to who and where we already are - in and thanks to difference. Difference, then, is the catalyst for an invitation to community in the here and now, in the very space between, in a space where neither can be reduced to the other. ${ }^{55}$

A theological hermeneutic of invitation also allows compassionate interpretive possibilities to become evident in the encounter shared between people of difference. It is a hermeneutic that resists the inclination to define and restrict others on account of external particularities. Rather than being divisive, difference is the very structure of existence that calls us to care well for the stranger, the friend, the sister, the brother, the lover, the self. In elaborating the biblical command given by Jesus of Nazareth to "love your neighbor," 56 Soren Kierkegaard offers a rich description of what it might mean to consider difference or "earthly dissimilarity"

In being king, beggar, rich man, poor man, male, female, etc., we are not like each other-therein we are indeed different. But in being the neighbor we are all unconditionally like each other. Dissimilarity is temporality's method of confusing that marks every human being differently, but the neighbor is eternity's mark on every human being. $[\ldots][\mathrm{T}]$ he neighbor is the common watermark, but you see it only by means of eternity's light when it shines through the dissimilarity. ${ }^{58}$ 
We are not the same. The world that we share is full of dissimilarity, which we make much of - because it is apparent. But difference is also what we share. A theological undertaking of dissimilarity as Kierkegaard suggests moves us both within and beyond our difference. We see the other. We cannot help but notice the difference, and in that divine invitation we are reminded and called to be and see as neighbors. The theological perspective names difference as the possibility of unity and communion rather than division. Who we are and what we share is difference and who we are and what we share is a community. Here we see the theological impetus of the hermeneutic: difference harbors and is a divine mystery that invites us to the other. Difference is a basic characteristic of being-with all others, not just some others. Fundamentalisms limit our responsive possibilities to difference and shelter us from perceiving the invitational impetus of the other. However, we are always with one another and the invitational hermeneutic I propose offers generative ways to be in community. This unifying hermeneutic is rooted in the understanding and practice of lived faith much like what Jantzen describes as "rejoic[ing] in the limited life we have," and "act[ing] for the love of the world." 59 It is a theological orientation similar to Peperzak's definition of religion as "the deepest dimension of human life, in which all other dimensions are rooted. ${ }^{, 60}$ It is a manner of being-with and welcoming difference as the divine invitation that appears in the coming of the other.

\section{Both a Feminist and a Theological Hermeneutic}

Considering transcendence and divinity in terms of the relation between two provides us with a distinctly feminist and theological undertaking concerning the fundamentalist phenomenon. If fundamentalism is a human inclination that universally affects our ways of being-with others in the world, and if our fundamentalist tendencies are manifest in poor ways of caring for others of difference, then the feminist theological hermeneutic that I propose helps to unveil difference as the site of the skewed interpretive framework of our varied fundamentalisms as well as alternative ways of interpreting and sharing the world with others. Fundamentalisms are interpretive constructs based on 
partial conceptions of the world. Fundamentalist hermeneutics constrain our responsive possibilities by either making too much or too little of difference. Fundamentalisms obscure the reality of the world or worlds, whereby we live convinced that available space - the in-between or middle ground between two - is meant to be taken rather than shared. The space between worlds is, on the fundamentalist's telling in diverse ways, "up for grabs." But, and hopefully so, the other in all his or her difference appears to us in this place between worlds. If difference makes way for invitations of the divine that arise within the relation between two, then a theological orientation will help uncover relational contexts where fundamentalisms are expressed, and will thereby reveal alternative interpretive possibilities in the everyday moments of being-with others.

\section{A Look Ahead}

Thus far I have outlined a framework from which I will further examine fundamentalist hermeneutics. With Heidegger's help we have come to understand that existence is hermeneutic. That is to say, we are naturally interpretive-we are always making sense of things. But our sense-making is limited by our being situated within particular historical, social, and cultural contexts. In addition, our interpretive possibilities are shaped by the shifting moods we inhabit throughout any moment of any given day. This hermeneutic structure of existence is evident in our responses to the objects and others whom we encounter. Here we arrive at the second vital understanding of being-in-theworld, namely that we are always with others. Being-with others brings us to the realization that existence is not only hermeneutic but also structured by care. Said differently, people matter to us and care is the name for the varying responsive possibilities available to us in the presence of another. Making sense of the world and caring for others with whom we share it: this is who we are and what we do. Care, then, is the condition for the possibility of both the positive and negative ways of being-with others. The hermeneutic care-structured nature of existence allows us to see the possibility of fundamentalist hermeneutics that shape our understanding of being-with 
others - which are often manifest in unchallenged ways of being-with that distort, diminish, and exaggerate difference.

Though fundamentalisms are pervasive and even basic to being human, our initial investigation has also demonstrated the hopeful possibility of alternative ways of seeing and being-with others. What we need is another vantage point from which difference might be understood and well cared for. What we need and what I propose is a feminist and theological hermeneutic that grants us awareness of our fundamentalisms and turns us toward others, inviting us to be mindful of the everyday moments of life and space shared between people of difference.

It is important at the outset to state the commitments that guide this project. First, the narratives that will be examined are biblical. I have chosen these stories because I believe they concern the "deepest commitments that shape us and the most significant truths that claim us." ${ }^{, 61}$ One need not be Jewish or Christian to appreciate the truthful possibilities harbored within these stories. Additionally, my choice to call upon biblical narratives to convey both the fundamentalist phenomenon and an alternative hermeneutic was intentional. I cannot help but agree with theologian and feminist philosopher Grace Jantzen who poignantly remarked, "[W]hether we like it or not the biblical texts and the religion built upon them have shaped the consciousness of western civilization; and we cannot, without violence to ourselves, cut ourselves off from our own formation. We can only struggle with it and against it: we ignore it at our peril.",62 The stories that will be examined in later chapters are familiar but suffer from traditional interpretive constraints. Thus the work of this project is first to reclaim these stories from fundamentalist interpretation and then to uncover the possibility within each narrative of alternative ways of making sense of being-with and sharing the world with others of difference.

Each of the subsequent chapters aims to uncover a feminist theological hermeneutic that may serve as a modification of our everyday fundamentalisms. Because fundamentalisms are manifest in impoverished forms of care for people of difference, each chapter examines both deficient and positive forms of solicitude 
practiced within particular relationships. Fundamentalisms are forms of care that collapse distinctions and neutralize differences. A feminist theological hermeneutic must take into consideration the particular ways difference might be uncovered and well cared for within specific contexts and relationships. In subsequent chapters I address positive forms of care in relationally distinct ways for the individual, the family, the community, and the world.

Chapter 2 examines the parable of the Good Samaritan as told by Jesus of Nazareth in the Gospel of Luke. This chapter considers fundamentalisms on an individual level which are often experienced between strangers. The parable and its narrator invite us to reinterpret ourselves as neighbors and friends and to care for others in accordance with who we might be rather than reducing ourselves and others to what we and others do, that is, the roles we play. In other words, we discover the who of our identity beyond the what to which we are often reduced. Some of the characters in the parable demonstrate a fundamentalism that obscures difference, whereas others bear witness to another way, a compassionate way, of caring for that difference.

Chapter 3 visits the story of Ruth the Moabite, who finds and makes an unusual family in Bethlehem with her embittered, widowed, childless, Jewish mother-in-law, Naomi. In this chapter fundamentalist inclinations are revealed within the rigid borders of the home and homeland. Family members and foreigners are the characters of Ruth's story who portray not only fundamentalisms but also alternative, rehabilitative way of cultivating and sharing the home as a space that welcomes and cares well for difference.

Chapter 4 offers a telling of the Jewish heroine Queen Esther and investigates fundamentalisms manifest in the social sphere. Fundamentalisms will be observed as a community practice where difference, though sometimes tolerated, is frequently generalized, objectified, and neutralized. In this chapter we arrive at an alternative interpretive framework of courageous concernful reticence taken up by members who dwell in communities of difference.

Chapter 5 examines the encounter between the Apostle Paul and a woman named Lydia. This chapter brings together the significant relational manifestations of 
fundamentalism evidenced in chapters 2, 3 and 4, and proposes an invitational universal way of seeing and being-with others. There are only two characters in this story, and the account is brief, but what we find is a beautiful rendering of what it might mean to share the world with others of difference. In Paul and Lydia we find strangers, neighbors, friends, foreigners, family, and community. And we arrive at a feminist theological hermeneutic that beckons us toward graceful hospitality in every gathering of difference.

A final word about the project: admittedly, I have chosen to depict the fundamentalist and her practices of care in stark, negative language. While fundamentalist inclinations are easily recognized by the most impoverished practices of care, they are not always, and not usually so obvious. Fundamentalist hermeneutics are common structural possibilities of being-with others in the world that distort difference and constrains our interpretive possibilities in various ways. We might consider fundamentalism on a continuum of degree and practice. As such, the purpose of this project is an excavation of the apparent and often most extreme instances of fundamentalisms. I examine the extreme and obvious in order to uncover the everyday, common, and acceptable fundamentalist inclinations at work in every encounter between people of difference. 
${ }^{1}$ Malise Ruthven, Fundamentalism: A Very Short Introduction (NY: Oxford University Press, 2007), 8.

${ }^{2}$ Ruthven, 5-6

${ }^{3}$ Adam Phillips, "On What is Fundamental" in Salmagundi, vol. 162/163, Spring 2009, 65.

${ }^{4}$ Phillips, "On What is Fundamental", 65.

${ }^{5}$ Wole Soyinka, "Mali and the Mad Clerics: Africa's Al-Qaida Clones are Not Religious, We Are Facing Viral Mutations of the Human Psyche," in The Guardian, 2 February 2013, 36.

${ }^{6}$ Soyinka, 36 .

${ }^{7}$ Soyinka, 36 .

${ }^{8}$ Justin Clemens, "The Science of Fundamentalism," in http://ethicalpolitics.org/seminars/justin-clemens.htm, 2006, 2.

9 “We needn't fear these radical nomads," in Belfast Telegraph 17 April 2010, 28-29.

${ }^{10}$ E.B.White, Charlotte's Web (NY: Harper Collins Children's Books, 1952)

${ }^{11}$ White, 28.

${ }^{12}$ White, 46

${ }^{13}$ White, 41.

${ }^{14}$ White, 183.

${ }^{15}$ I am indebted to Dr. Robert R. Johnson for this helpful definition of mindset, which he developed in Romancing the Atom: Nuclear Infatuation from the Radium Girls to Fukushima (Santa Barbara, CA: Praeger Press, 2012)

${ }^{16}$ Spelman, 162.

${ }^{17}$ Elizabeth W. Spelman, Inessential Woman: Problems of Exclusion in Feminist Thought (MA: Beacon Press, 1988), 2-3.

${ }^{18}$ Matthew 25:34-40, "Then the king will say to those on his right, 'Come, you who are blessed by my Father, inherit the kingdom prepared for you from the foundation of the world. For I was hungry and you gave me food, I was thirsty and you gave me drink, I was a stranger and you welcomed me, I was naked and you clothed me, I was sick and you visited me, I was in prison and you came to me.' Then the righteous will answer him saying, 'Lord, when did we see you 
hungry and feed you, or thirsty and give you a drink? And when did we see you a stranger and welcome you, or naked and clothe you? And when did we see you sick or in prison and visit you?' And the king will answer them, 'Truly I say to you, as you did it to one of the least of these, my brothers you did it to me."”

${ }^{19}$ Adriaan Theodoor Peperzak, "Wonderment and Faith," in Philosophy Between Faith and Theology: Addresses to Catholic Intellectuals (IN: University of Notre Dame Press, 2005), 117118.

${ }^{20}$ Martin Heidegger, Being and Time, edited by John Macquarrie and Edward Robinson. (NY: Harper \& Row Publishers, 1962)The next few paragraphs contain paraphrased sections from Part One, Division One, Sections IV, V, and VI.

${ }^{21}$ Heidegger, Being and Time 43.

${ }^{22}$ Heidegger, Being and Time, 191.

${ }^{23}$ Heidegger, Being and Time, 177.

${ }^{24}$ Heidegger, Being and Time, 152.

${ }^{25}$ Heidegger, Being and Time, 155.

${ }^{26}$ Heidegger, Being and Time, 158-159.

${ }^{27}$ Heidegger, 165

${ }^{28}$ Heidegger, $165 \& 213$

${ }^{29}$ Heidegger, 165

${ }^{30}$ Heidegger, 191. "In every case this interpretation is grounded in something we have in advance - in a fore-having...In every case interpretation is grounded in something we see in advance-in a fore-sight. This fore-sight takes the first cut out of what has been taken into our fore-having, and it does so with a view to a definite way in which this can be interpreted...In either case, the interpretation has already decided for a definite way of conceiving it, either with finality or with reservations; it is grounded in something we grasp in advance-in a foreconception."

${ }^{31}$ Heidegger, 163

${ }^{32}$ Heidi Bostic, "Luce Irigaray and Love,” Cultural Studies 16.5 (2002), 606.

${ }^{33}$ Luce Irigaray, "Love of Same, Love of the Other," in, An Ethics of Sexual Difference.(London: Continuum, 2004), 85. 
${ }^{34}$ Irigaray, Between East and West, (NY: Columbia University Press, 2002), 137.

${ }^{35}$ Elizabeth V. Spelman, Inessential Woman: Problems of Exclusion in Feminist Thought (Boston, MA: Beacon Press, 1988), 102.

${ }^{36}$ Spelman, 113.

${ }^{37}$ Serene Jones, "Feminist Theology and the Global Imagination," in The Oxford Handbook of Feminist Theology eds. Mary McClintock Fulkerson and Sheila Briggs (NY: Oxford University Press, 2012), 26.

${ }^{38}$ Jones, "Feminist Theology and the Global Imagination," 42.

${ }^{39}$ Irigaray, Way of Love, translated by Heidi Bostic and Stephen Pluháček (NY: Continuum, 2002), 144.

${ }^{40}$ Jones, Feminist Theory and Christian Theology: Cartographies of Grace (Minneapolis MN: Fortress Press, 2000), 4.

${ }^{41}$ Grace Jantzen, Becoming Divine: Towards a Feminist Philosophy of Religion (IN: Indiana University Press, 1999), 165.

${ }^{42}$ Jantzen, Becoming Divine, 152-153.

${ }^{43}$ Jantzen, Becoming Divine, 169.

${ }^{44}$ Carol Gilligan, In a Different Voice: Psychological Theory and Women's Development, (MA: Harvard University Press, 1993)

${ }^{45}$ Nel Noddings, Caring: A Feminine Approach to Ethics and Moral Education (CA: University of California, 2003)

${ }^{46}$ Daryl Koehn, Rethinking Feminist Ethics: Care, trust and empathy, (London: Routledge, 1998), 24.

${ }^{47}$ Noddings, Caring, 10. Cited in Koehn, Rethinking Feminist Ethics, 22.

${ }^{48}$ Koehn, 5 .

${ }^{49}$ Koehn, 8 .

${ }^{50}$ Koehn, 9 .

${ }^{51}$ Revelation 3:20 
${ }^{52}$ Peperzak in "Retrieving Onto-Theo-Logy," in Philosophy Between Faith and Theology: Addresses to Catholic Intellectuals (IN: University of Notre Dame Press, 2005), 96.

${ }^{53}$ Irigaray, "Love of Same, Love of Other," 92-93.

${ }^{54}$ Irigaray, The Way of Love, 147.

55 Irigaray, I Love to You, translated by Alison Martin (NY: Routledge, 1996), 104-105.

${ }^{56}$ Matthew 22:39

${ }^{57}$ Soren Kierkegaard, "You Shall Love the Neighbor," in Works of Love. eds Howard V. Hong and Edna H. Hong (NJ: Princeton University Press, 1995), 61-90.

${ }^{58}$ Kierkegaard, "You Shall Love the Neighbor," 89.

${ }^{59}$ Jantzen, 155.

${ }^{60}$ Peperzak, "Philosophy—Religion-Theology," in Philosophy Between Faith and Theology: Addresses to Catholic Intellectuals (IN: University of Notre Dame Press, 2005), 74.

${ }^{61}$ Jones, "Feminist Theology and the Global Imagination," 42.

${ }^{62}$ Jantzen, Becoming Divine, 107. 


\section{Chapter 2: Compassion Between Strangers}

\section{Overview}

Because where we stand affects how and whom we see, possibilities for care are often encumbered by relational particularities. In other words, we see and thus treat people differently based on who they are to us. Others are similar, familiar, different, and strange to us. These markers of likeness offer categories through which we choose forms of care. Though this disparate treatment is natural and even necessary, fundamentalist hermeneutics that makes too much or too little of difference frequently begins with the false notion that the world would be better if shared by the similar and the familiar, rather than the different and the strange. Fundamentalists of any sort, be they religious or not, are unaccustomed to caring well for strangers because positive forms of care are often limited to people with whom they share something in common. Speaking to the human struggle with differing and often conflicting desires, psychoanalyst Adam Phillips writes: "within our so-called relationships we always find a clash of fundamentalisms, conflicts about what is fundamental and what it is to acknowledge these fundamentals. In this sense people always meet each other, people come across each other at an impasse."1 The forms of care we extend to one another appear to us within these clashing constraints. Thus, in the pursuit of our desiresdesires tempered by what is fundamental — we care poorly for others of difference. Though fundamentalisms are certainly manifest within intimate and familial relations, which I will uncover in later chapters, these hermeneutics are apparent between strangers. Thus, I begin with hermeneutic possibilities and practices of care extended between strangers.

In this chapter I examine common fundamentalist inclinations of strangers by considering the biblical narrative of the Good Samaritan. The characters in the story depict various fundamentalisms and help to address a few of the hermeneutic possibilities of being-with unfamiliar others. Building upon Heidegger's description of the they, I will demonstrate that fundamentalist hermeneutics constrain our relations 
with others by promoting superficial curiosity and encouraging constant unreflective chatter or idle talk about the others and objects in the world. Curiosity and idle chatter are everyday ways of the they which conceal the force of our fundamentalisms and limit our perception of alternative interpretive possibilities. Following the discussion of curiosity and idle talk, I then propose that turning away from difference is the bodily comportment of fundamentalist hermeneutics between strangers. I support this claim by turning to the concept of the "reactive subject," as described by Alain Badiou. I then move to uncover fundamentalist inclinations in terms of varying distortions of difference and preferences for similarity. Heidegger's understanding of solicitude or care as leaping in further clarifies commonplace fundamentalist inclinations. I then consider Heidegger's notion of leaping ahead in order to uncover alternative hermeneutic possibilities for being-with strange others. The final moments of the chapter articulate an invitational feminist theological hermeneutic marked by compassionate response to difference.

For some readers the Samaritan's story is familiar. Other readers may find this story unsettling or unfamiliar. With these preconceptions in mind, I invite readers to graciously join me with an openness to the text that allows us to imagine this story anew. It is a story that does what Richard Kearney describes as "transporting us to other times and places where we can experience things otherwise." ${ }^{.2}$ Stories help us see things differently. Kearney writes:

[Stories] afford[s] us a singular mix of pity and fear whereby we experience the suffering of other beings as if we were them. And it is precisely this double-take of difference and identity-experiencing oneself as another and the other as oneself - that provokes a reversal of our natural attitude to things and opens us to novel ways of seeing and being. ${ }^{3}$ 
The story of the Samaritan confronts us with the reality of our own fundamentalisms and helps us see that things and we might be otherwise. Compassion is rare. Yet in the telling of this story we find that compassion is possible, even and especially between strangers.

\section{Narrative: The Good Samaritan}

Two thousand years ago a parable was given in answer to a question that haunts us still. The question "Who is my neighbor?" rang out in response to a hard teaching about love that Jesus of Nazareth had just given. The man who questioned, a lawyer by trade, wanted to love but he wasn't quite sure about who he was willing to love. It is a story that addresses what it means to be in the world where others of difference reside. It is a story that when thoughtfully considered calls to mind both the tragedy and the hope of our shared existence in this world we share with others of difference.

A man while traveling from Jerusalem to Jericho was brutally attacked by thieves along the way. After the assault he was left bruised, bloody, and nearly unconscious on the side of the road. He was left there to die. A little while later a priest too made his journey down the thief-infested highway. He saw the wounded man from a distance and decided to cross to the other side of the road. A few hours later another man, a high-ranking religious official, a Levite, also happened down the road. He too passed by and around the battered victim. A little later still another man only described by his ethnic affiliation, a Samaritan, ventured down the highway. Upon seeing the body wrecked by violence, he stopped. The Samaritan did not know the wounded man. But he knelt down, bound his wounds, gave him drink, and transported him to the nearest inn, where he supplied the financial means to care for his physical recovery. The compassionate Samaritan is the neighbor. Here is the full text of the short parable:

And behold, a lawyer stood up to put him to the test, saying, “Teacher, what shall I do to inherit eternal life?" He said to him, "What is written in the Law? How do you read it?" And he answered, 
"You shall love the Lord your Lord with all your heart and with all your soul and with all your strength and with all your mind, and your neighbor as yourself." And he said to him, "You have answered correctly; do this and you will live." But he, desiring to justify himself, said to Jesus, “And who is my neighbor?” Jesus replied, “A man was going down from Jerusalem to Jericho, and he fell among robbers who stripped him and beat him and departed, leaving him half dead. Now by chance a priest was going down that road and when he saw him, passed by on the other side. So likewise a Levite, when he came to the place and saw him, passed by on the other side. But a Samaritan, as he journeyed, came to where he was, and when he saw him, he had compassion. He went to him and bound up his wounds, pouring on oil and wine. Then he set him on his own animal and brought him to an inn and took care of him. And the next day he took out two denarii and gave them to the innkeeper, saying, 'Take care of him, and whatever more you spend, I will repay you when I come back.' Which of these three, do you think, proved to be a neighbor to the man who fell among the robbers?" He said, "The one who showed him mercy." And Jesus said to him, "You go, and do likewise.,"

The characters in this story bring to life a question that is intensely contemporary but often ignored. The lawyer seems strangely aware that something is missing - he fails to love his neighbors, not because he is actually unaware of who they are, but because he is unwilling to be a neighbor. We too ask his question: Who is my neighbor? And much like this lawyer we know, or at least we have an inkling, that things could be better. The Samaritan's neighborliness is found in the mercy he lavishly extends to the wounded stranger. He sees and cares for a man he does not know.

The Samaritan's story helps to disclose how we might begin to consider the compassionate possibility of extending ourselves with neighborly care for strangers. In 
the human condition we find ourselves and we find possibilities for being-with others. Human nature, fallen as it is, flees from possibilities of compassion that often appear in the presence of the diverse others with whom we share the world. ${ }^{5}$ We struggle in the world, desiring that things be otherwise but lacking the understanding and the courage of thought and practice to live well with others. Yet compassion is possible, and the parable of the Samaritan points toward such a possibility.

\section{Fundamentalism in Plain Sight or Turning from Difference}

Before examining compassionate possibilities of response we must first attend to the fundamentalist hermeneutics frequently present between strangers. In the first chapter we called upon the work of Martin Heidegger and established fundamentalist hermeneutics to be historical manifestations of the they. That is to say, our everyday ways of being-with others in the world are unreflective, average, and widespread. The they frees us from thinking about things by providing efficient interpretive constructs and habits of response while forgoing the difficult task of thoughtful engagement with the others and objects within our worlds. Recall that Heidegger does not limit the they to a subgroup of mindless people. Instead he asserts that all have already been caught up in a "tranquilizing" fallenness that alienates them from themselves. ${ }^{6}$ Fallenness and the everyday experience of the they is outwardly manifest in poor ways of being in the world with others. This manifestation takes three interrelated forms: idle talk, curiosity, and ambiguity. In fallenness, rather than lingering and learning or waiting for understanding, we are curious and constantly distracted by attraction after attraction. Fallenness is also evident in communicative habits of the they where gatherings are often filled with the noisy sound of idle talk that does not allow for understanding but exchanges the work of meaning-making and thinking for an "undifferentiated kind of intelligibility."7 Heidegger writes:

Ontologically this means that when Dasein maintains itself in idle talk, it is as Being-in-the-world cut off from its primary and primordially 
genuine relationships-of-Being towards the world, towards Dasein-with, and towards its very Being-in. Such Dasein keeps floating unattached yet in so doing, it is always alongside the world, with others, and towards itself. $^{8}$

Instead of thoughtfully engaging in the world, idle talk allows us to run "alongside" the world unreflectively scratching the surface of our being and missing possibilities of being-with others. Idle talk is supported by a sense of knowledge that has been acquired without the struggle or even the questioning necessary to understand what is at hand. This imagined sense of understanding is characterized by what Heidegger calls ambiguity. ${ }^{9}$ Existence is marked by fallenness or entanglement with the objects and others in the world and is frequently occupied with idle talk, mere curiosity, and ambiguity. By existing alongside, scratching the surface of togetherness, and ever evading nearness, fallenness contributes to a perpetual state of distraction, busyness, and a sense of homelessness that constrain our interpretive and responsive possibilities for being-with. The inability to envision better possibilities of being-with and the uncritical acceptance of the attitudes and actions of the they that characterize being are precisely the problems of fundamentalism. In other words, fundamentalisms might be said to be the particular manifestations of fallenness in the twenty-first century.

One of the fundamentalist ways of being-with that affirms the banal, fallen practices of the they is evidenced in a bodily comportment of turning aside from difference. When encountered by difference fundamentalist hermeneutics subtly encourage us to pass by and around one another as if pretending the other does not exist. Turning aside is much like the game of hiding often played by small children who simply close their own eyes thus believing that all others are no longer present. The child has shut his eyes but others are still in the room proclaiming, "You cannot see me and we are not here together because I cannot see you." Turning aside is not a matter of the physical ability to see but rather an intentional covering over, a shielding of oneself from difference. 
Alan Badiou speaks of truth as an event or a rupture of the world. In the wake of such rupture, which comes in various forms, we are met with the invitational possibility of accepting or rejecting truth's event. What is granted in the event is new and always world changing. While some people accept the event and the personal/political possibilities harbored therein, others ignorantly refuse its coming. Badiou names these refusers "reactive subjects" and of these subjects he writes:

In one sense the reactive subject denies the event's effectiveness since it maintains that the previous world can and should go on as it is. It preserves an insurmountable distance between itself and the new political present. It transforms its non-presence to the new present into a false present. Yet, in another sense it accords the utmost consideration to the new body's existence. In particular under various forms [...], it will multiply concessions made to workers, drawing up a social policy and curbing the unlimited appetites of financial and industrial powers, on the condition that all this remains within the framework of the previous order $[\ldots]$. By creating new ways of keeping the present of the True at a distance, it maintains the semblance of continuity. ${ }^{10}$

These characteristics of the reactive subject are similar to the fundamentalist inclinations I describe as always already being caught up in the attitudes and activities of the they. The reactive subject turns aside, realizing the difference by which she has been encountered but choosing to go on as if the other simply were not there. This fundamentalist is distanced from the reality of the other and strives to pretend things are the same as they have always been. Turning aside is the fundamentalist's orientation away from difference. It is regularly a first response offered to others when encountered by difference. It is a false sense of security made possible in the refusal of the difference of another, on account of that difference. It is the creation of policies and procedures 
designed to maintain the status quo. Fundamentalist hermeneutics are reflected in a turning from rather than toward others of difference.

\section{The Levite and the Priest}

Fundamentalist turning aside is vividly depicted in the parable of the Samaritan. And so, I turn to these characters in order to demonstrate the skewed interpretive and responsive possibilities of fundamentalist hermeneutics between strangers. We cannot ignore the loveless way in which the Levite and the priest relate to the wounded man. We cannot pass by their inaction, because these men are not merely characters in a nicely told parable about one man's act of compassion. Rather, these men offer a picture of the possibilities of fundamentalist inclinations. The poor care-witnessed in the total abandonment of the wounded man by the Levite and the priest - is reflective of the fundamentalist tendencies, understood in its most extreme sense as a violent and dehumanizing way of being in the world that is evidenced in the rejection of another. The Levite and the priest see the wounded man, just as the Samaritan does, but they turn away and pass to the side of the road. The Levite and the priest come face to face with a wounded other - a man whose apparent difference was at once repulsive and divisive as well as banal and easily forgettable. This wounded man called to mind a shared fragility they had long desired to erase from perception and memory and a common humanity they ignorantly refuse.

On the one hand the Levite and the priest exaggerated the difference that separated them from the wounded man. On the other hand they diminished that difference. To be sure, neither of these men were aware of the fundamentalism that filtered their responsive possibilities for the wounded man. They were busy and on the way to something and they did not know him. He was not a part of their agendas and his difference was divisive. Just as they were ignorant of their fundamentalist inclinations, they were also unaware of alternative hermeneutic possibilities. Consequently, the compassion that was available to the Samaritan and certainly possible for the Levite and the priest, was not a choice of which they were cognizant. They could not get beyond 
the wounded man's strangeness. Kierkegaard attends to this matter of external difference and likens it to a cloak that if wrapped too tightly conceals the wonder of the other. He writes:

We seem to have forgotten that the dissimilarity of earthly life is just like an actor's costume, or just like a traveler's cloak, so that each one individually should be on the watch and take care to have the outer garment's fastening cords loosely tied, and above all, free of tight knots so that in the moment of transformation the garment can be cast off easily. [...] But, alas, in the life of actuality one laces the outer garment of dissimilarity so tight that it completely conceals the fact that this dissimilarity is an outer garment, because the inner glory of equality never or very rarely shines through as it continually should and ought. ${ }^{11}$

We appear to each other clothed in the linen of dissimilarity. And external difference(s) are part, not the whole, of who we are. ${ }^{12}$ Differences often cover over what we share: a fragile humanity, an equality long concealed by external markers of dissimilarity. Herein we find evidence of fundamentalist hermeneutics. Fundamentalisms interpret others by evident differences and fail to acknowledge what is human and what is being concealed by that difference. Within fundamentalist hermeneutics we are estranged from one another on the basis of external particularities. This mutual estrangement bears evidence of what Heidegger described as being alongside, but not near or with one another. Fundamentalist inclinations encourage running alongside, but never with difference constantly turning away and refusing to look beyond what seems to be a divisive external dissimilarity. Difference is thus misperceived and our fragile humanity, or the "inner glory of equality" is concealed. Arthur Sutherland describes the problem with misunderstanding and thereby objectifying the stranger and writes: "We should see others (neighbors, enemies, and strangers) in such a way that they are visible to us not as a mere object but as a reflection of our own fallen and redeemed humanity. 
Seeing is inhuman if it is not the seeing of another human."13 Though we might be hindered by the external difference of another, fundamentalisms begins not with the other, but with ourselves. What is at stake in our varied fundamentalisms is also what is shared. What the stranger needs, what we need is a reorientation toward the difference that cloaks our every encounter.

The Levite and the priest help us to admit the Samaritan's compassionate choice was not simple. Though he was moved to care, he too could have done otherwise. He did not have to bind the man's wounds, carry him to the inn, and pay for his stay. He could have settled for less. He struggled with the dead weight of an unknown wounded man and in that struggle he was compassionate. We are not unlike the Levite and the priest who found themselves on the highway in the direction of the wounded man. We share the world with people of difference. These are others, like the wounded man, who may be easily brushed aside as we navigate the pressing details of our days. The Levite and the priest serve to remind us just how fallen we are. They provide us with characters who call us to admit our own fundamentalist inclinations.

\section{The Lawyer}

The Levite and the priest are depicted as unkind and without compassion. Their actions are deplorable. At the end of the story, having judged them, we often come away feeling self-assured. But the Levite and the priest are not the only characters to exhibit fundamentalist tendencies in the narrative. Similar to the Levite and the priest who exaggerate difference and turn aside, the lawyer diminishes difference and in so doing he also turns aside. In an act of willful blindness he only sees those who are similar. He is willing to love his neighbors as long as his neighbors are not strangers. By asking, "who is my neighbor?" the lawyer makes clear his desire to care for a particular person - a neighbor who is recognizable, similar, easy to care for. The lawyer's fundamentalism is not obvious. His question seems reasonable. After all, how can he help if he does not know who is in need? How could he be prepared for compassion if unable to tell who required it? These are the questions of the lawyer. In order to see his 
neighbors he had to know who they were. His neighbors could not be anyone, they had to be someone. This is a fundamentalism that does not want to bother with the unknown - as if difference were not a part of the world. The lawyer claims the inability to see and recognize his neighbors because he prefers people who do not seem all that different from himself. He does not wish to see the difference and thereby justifies inability to recognize his neighbors.

In the lawyer we find two crucial characteristics of fundamentalist hermeneutics. First, fundamentalisms are usually concealed from awareness. Recall Heidegger's notion of the they. Fundamentalism is a hermeneutic structural possibility of being-with others in the world - patterns of interpretation wherein difference is distorted. However, this distortion rarely appears as such. What has been skewed by fundamentalism has long been taken as the everyday normal interpretive possibilities of being-with. These enveloping fundamentalisms are much like a description Luce Irigaray has given to the masculine world which has been built without acknowledging sexuate differentiation. She writes: "The world, or worlds, that he constructs will close over him so tightly that reaching something outside him becomes difficult for him." ${ }^{14}$ Fundamentalist hermeneutics cover over and wrap around us such that reaching out and interpreting otherwise is difficult. Our fundamentalisms go unquestioned because they are a normal, common way that difference has been perceived for as long as we can remember. The lawyer's sincere question reveals the hidden nature of interpretive constructs: His question is reasonable and he is unaware of his fundamentalist inclinations.

The second fundamentalist characteristic demonstrated by the lawyer is found in his desire to preserve and promote sameness. He wants to love only those neighbors who appear to him as neighbors. He needs easily recognized neighbors who share qualities that make them so. In the search for those who are similar the lawyer misperceives those who are strange and different. Fundamentalist hermeneutics often disregard difference in order to preserve a false sense of purity maintained by similarity. Again Irigaray is helpful. Describing this preservation of sameness in terms of totalitarian standardization she writes: 
This standardization from below is not as perceptible as the standardization overtly ordered by a dictator. But it exists and it manifests itself through many signs: the refusal of the foreigner is one such index $[\ldots]$. In this basic standardization, this predetermined belonging to the same world, the relations between individuals pre-exist the meeting between two particular individuals. They are inspired, dictated, ordered by norms, habits, styles that surreptitiously lay down the law, including love and desire. ${ }^{15}$

Irigaray's definition highlights the consequences of participation within the they. Fundamentalisms are predetermined belongings wherein relations are allowed and prohibited. Possibilities of love, desire, compassion, etc. are filtered through the hermeneutics of the they in which we always already reside. Fundamentalisms help to establish accepted and popular practices of being-with in order to maintain the illusion of similarity. Assimilation is the cry of the fundamentalist they who cherishes sameness and diminishes difference. Fundamentalisms are the everyday ways of being-with that preserve similarity at the expense of difference. The stranger must be strange. Her difference places her outside the fundamentalist's frame of awareness so that neighbors can only ever be those who are, or at least appear to be, similar. The lawyer's question is indicative of a nearly undetectable fundamentalist hermeneutic and is marked by the seemingly reasonable desire to promote and preserve an imagined sense of sameness.

\section{Fundamentalism as Philanthropy, Leaping In, the Empathetic Fundamentalist}

Sometimes fundamentalisms are manifest in obvious practices of unkindness, as witnessed in the turning aside of the Levite and the priest. But most often fundamentalisms are hidden interpretive constructs wherein difference is neutralized as part of the normal, everyday manner of being-with others in the world. In the Samaritan's charity we find an empathetic way of being-with that conceals common 
fundamentalist inclinations. Empathetic fundamentalisms do not require religious justification for contributing to the needs of others. This is an empathy often marked by generous giving, fundraising, and public acknowledgment of the presence of the needy. Within empathetic fundamentalist hermeneutics difference offers a system of classification, but not a neighborhood. These hermeneutics interpret difference in ways similar to the masculine ethical mistake described by Luce Irigaray of "subordinating women to destiny without allowing them any access to mind, or consciousness of self and for self." ${ }^{, 16}$ Attending to the material and physical needs of the other is vital, but it is not the only important work of care. Empathetic fundamentalisms promote a practice of compassion similar to Heidegger's description of "leaping in" for another. He writes:

This kind of solicitude takes over for the Other that with which he is to concern himself. The Other is thus thrown out of his position; he steps back so that afterwards, when the matter has been attended to, he can either take it over as something finished and at his disposal, or disburden himself of it completely. In such solicitude, the Other can become one who is dominated and dependent, even if this domination is a tacit one and remains hidden from him. This kind of solicitude, which leaps in and takes away 'care', is to a large extent determinative for Being with one another $[\ldots]{ }^{17}$

Leaping in is noble, even necessary work. Helping those who cannot help themselves is a mantra of empathetic fundamentalisms. But this compassion stops short. It concludes when the work for and with the other is not yet done. Compassion empathetic fundamentalisms unintentionally exaggerate difference by taking comfort in making much of the difference of the other. Difference can remind us that we are nothing like them, neatly divide the haves from the have nots, and safely place strangers on the outside of the neighborhood. Additionally, this impoverished care helps eliminate immediate pressing troubles for the other but does not allow that other to be a part of 
the process or come to an understanding of how she might free herself of such troubles in the future. Empathetic fundamentalist hermeneutics encourage impoverished compassion for others. This compassion is frequently limited to surface level details and often results in the quick return of that other to her poverty.

\section{The Samaritan}

Having heard the lawyer's question we recognize his error. It is easy to identify with the Samaritan, who is often described as "good" though this moniker is never actually assigned to him in the narrative. But what if it were the case that the Samaritan were not that good after all? What would it mean to say that he too was bound by fundamentalisms? Of course I cannot deny that his actions were generous and neighborly, especially when compared with the actions of the other characters. What he did for the wounded man was benevolent. But the Samaritan's care ended at the inn. He left the work of recovery in the hands of the innkeeper, dropping off the wounded man and heading on his way. Note that the Samaritan did not bring or invite the wounded man to his own home- - he was taken to an inn. Admittedly, this interpretation of the Samaritan's actions is harsh. Yet his compassion reflects a particularly contemporary and empathetic version of fundamentalist hermeneutics. Of course he was compassionate. Yes, he was different from the Levite, the priest, and the lawyer. However, his compassion was reserved. Though difference did not hinder him from attending to the physical needs of the wounded man, difference allowed the Samaritan to objectify the stranger and perhaps to satisfy his fundamentalist inclinations. Empathetic fundamentalisms often interpret difference as exotic and pitiful reasons to care superficially for one another without personal investment or commitment in the other's understanding of herself.

Perhaps this depiction of the Samaritan is disingenuous. Indeed, at the end of the parable the lawyer is advised to be a neighbor, just as the Samaritan was a neighbor to the wounded man. Contrary to the traditional interpretation of Jesus' command to "Go and do likewise," - an interpretation that rests solely on the actions of the Samaritan-I 
offer another, perhaps more human, telling. What is most hopeful about the parable is common to both the Samaritan and the lawyer and has little to do with the "good" usually ascribed to the title character. Neither the Samaritan nor the lawyer are wholly constrained by their varied fundamentalisms. The questioning lawyer is part of a conversation that could significantly alter his ways of being-with others and the Samaritan shows unusual compassion to the wounded stranger. The Samaritan and the lawyer reveal a hopeful reality of hermeneutic existence: there are many ways and multiple meanings available to us in every relational encounter. Fundamentalist hermeneutics are not the only interpretive possibilities we have. We too have been granted alternative possibilities of response wherein compassion need not be so rare or impoverished after all.

\section{Compassionate Leaping Ahead: Jesus}

The harsh reality of the world that appeared to Jesus in the presence of the questioning lawyer and to the Levite, the priest, and the Samaritan in the broken body of the wounded man bears evidence of the fundamentalist hermeneutics we also endure. We are the lawyer straining to interpret and respond to others of difference. We are the wounded man - run down by the world, waiting for the merciful hands of another. We are the Levite and the priest - frenetically busying ourselves with endless tasks, meaningless worship, and banal impressions of our own fleeting importance; justifiably turning away from others along our paths. We are the Samaritan at ease with our charitable contributions and altruistic endeavors. Within fundamentalisms we are absorbed, even lost, in what we do, having forgotten who we are. ${ }^{18}$ Importantly, we are not limited to fundamentalist responsive inclinations: we too can compassionately attend to our neighbors. The power of this story is found in the conversation that instigates the parable. The lawyer questions and Jesus responds, inviting the lawyer to consider his own interpretive restrictions and to respond to difference otherwise.

This narrative points to a further reality that mirrors the struggle of our fundamentalist inclination; in the obvious contrast between the Levite, the priest, and 
the Samaritan we glimpse a wondrous truth. The Samaritan is not a person but a story whose truth was meant to invite its audience out of the slumber of their fallenness. Jesus, the narrator, attends to the loveless question by opening up the lawyer's "theyrestricted" vision, offering other possibilities for understanding the self and being-with others. Jesus understands and Ramsey Eric Ramsey rightly asserts that while "[i]n theory the real is vastly open and filled with possibilities, existentially, for many reasons, these possibilities are not immediately actualizable." 19 The "good" in the story is found in Jesus' leaping ahead to care for the lawyer. He is good to the lawyer in a way the Samaritan does not quite understand - not because he literally stops and heals the physically wounded one, but because he hears the lawyer's question as a reflection of the fallenness of existence and stops to share a compassionate conversation along the way. Jesus provides a new interpretive framework from which the lawyer might catch a glimpse of other ways of being-with.

In Heidegger's terminology, the Samaritan in the story "leaps in" for the wounded man, doing what the wounded man could not do for himself. By contrast, Jesus "leaps ahead" of the lawyer and helps him toward possibilities of authentically dwelling in the world. Describing leaping ahead Heidegger writes:

[T] here is also the possibility of a kind of solicitude which does not so much leap in for the Other as leap ahead of him in his existentiell potentiality-for-Being, not in order to take away his 'care' but rather to give it back to him authentically as such for the first time. [...] [I]t helps the Other become transparent to himself in his care and to become free for it. ${ }^{20}$

As we witness Jesus' leaping ahead we find an invitational hermeneutic of compassion that attends not only to the physical needs of the strangers, but also to the very possibilities of being in the world with others of difference. Jesus' care brings the lawyer back to his senses; he brings the lawyer to a better understanding of what it 
could mean to be-with others in the world. Feminist theologian Rosemary Radford Ruether articulates such an experience as a "liberating encounter with our authentic selves resurrected from underneath the alienated self. [...] [N]ot experienced against, but in and through relationships, healing our broken relations with our bodies, with other people, with nature." 21 As we move about the world, our every encounter with others of difference offers the hopeful possibility of compassion to witness and share in the humanity of another. This hermeneutic responds with compassion to the bodily needs of the difference of the other and in so doing purposely attends to the liberation of the "authentic" self of that other. Irigaray uses the term "becoming" to signify this liberating work shared in relation with the other and writes, "Between the two is thus preserved a becoming that is still to be elaborated - for the one, for the other and for their relations. It is a sort of always virginal space safeguarded through the attention that each one accords to the other in their transcendent alterity., ${ }^{, 22}$ Becoming is allowed in the space shared between people of difference. An invitational hermeneutic of compassion sees and responds to the difference of the other so as to assist their mutual becoming, leaping ahead so that the other is freed to understand things differently about herself, her fundamentalist inclinations, and her world.

In Jesus' conversation with the lawyer we find a hermeneutic that can modify the fundamentalisms so prevalent in ourselves and in our relations with strangers. We too have habituated ourselves to exclusionary ways of being and cheap versions of charity. Jesus' readiness to have a compassionate conversation with the lawyer, a man whose difference was evident in one simple question, demonstrates a life habituated to caring well for others. Jesus saw through the cloak of dissimilarity that was tightly wrapped around the lawyer and encouraged him to see through that dissimilarity - a cloak that had long-clothed the lawyer and his neighbors. Kierkegaard describes a compassionate mercy that may not awaken amazement from spectators, but flows out of poverty and is carried out from an inward understanding and reflection of the mercy of the divine. ${ }^{23}$ This compassion is a movement of the heart to care and is not limited to 
the "things" that can be done for the other, but begins as an inner compulsion not dependent on material resources:

It follows naturally of itself that if the merciful person is able to do something, he is only too glad to do it. But that is not what we wanted to focus attention upon, but rather upon this, that one can be merciful without being able to do the least thing. This is of great importance, since being able to be merciful is certainly a far greater perfection than to be able to do something.[...] If someone has cut off my hands, then I cannot play the zither, and if someone has cut off my feet, then I cannot dance, and if I lie crippled on the shore, then I cannot throw myself into the sea in order to rescue another person's life, and if I myself am lying with a broken arm or leg, then I cannot plunge into the flames to save another's life—-but I can still be merciful. ${ }^{24}$

Kierkegaard rightly suggests that mercy has little to do with what one does for another, and everything to do with how it is done. Mercy is about how, not what. Jesus' care had to do with greeting the material needs of the lawyer with liberating words uttered through a compassionate stance toward difference. Prior to the conversation with Jesus the lawyer was in many ways without hope-Jesus demonstrates that the lawyer was similar to the Levite and the priest. The lawyer is encumbered by difference, he does not want to see others, he prefers to turn away from the stranger. But in the telling of the parable, Jesus offers hope to the lawyer - a compassionate hermeneutic, the wherewithal to care well for others of difference, whoever and wherever they may be. Here is a compassionate mercy experienced amid the shared struggle and suffering of fallenness. 


\section{Compassion Between Worlds of Difference}

The kind of compassion that I describe, which is the outward manifestation of a hermeneutic that invites us to other ways of being-in-the-world, is both feminist and theological. It is a compassion that pays attention to the mundane, everyday struggle of being. It is a compassion that actively engages in the cultivation of difference for the mutual flourishing of all. Recognizing, as Grace Jantzen has asserted that "it is not possible to emphasize flourishing wihout emphasizing also the material conditions of people's lives as they are lived now, here, upon this earth, in relation to one another." 25 It is a human interpretive possibility wherein the horizon of our vision is expanded to include and welcome others who don't quite seem to fit in our habitual yet oppressive categories and congregations.

In contrast with the care exhibited by the Levite and the priest, the moment the Samaritan catches sight of the wounded man, he is moved with compassion to care for the stranger. Similarly, Jesus is not limited by, but has been freed to attend to, the fundamentalisms expressed by the questioning lawyer. This compassion does not objectify or restrict the difference of the wounded one. ${ }^{26}$ Compassion is mindful of the cry of the marginalized, unheard, invisible ones. Out of compassion these characters struggle through the culturally accepted, fundamentalist tendencies that distort difference for the sake of imagined sameness or oppressive discrimination. The compassionate one resists the natural desire to protect himself from the unknown and the urge to categorize others solely on account of difference. Radford Ruether offers a rich description of what compassion for and through difference might look like within a feminist hermeneutic:

Women, as the denigrated half of the human species, must reach for a continually expanding definition of inclusive humanity - inclusive of both genders, inclusive of all social groups and races. [...] This is not a question of sameness but a recognition of value, which at the same time affirms genuine variety and particularity. It reaches for a new mode of 
relationship, neither a hierarchical model that diminishes the potential of the "other" nor an "equality" defined by a ruling norm drawn from the dominant group; rather a mutuality that allows us to affirm different ways of being. ${ }^{27}$

Compassion that is cognizant and purposely inclusive of of "different ways of being" is precisely the practice of care portrayed in varying degrees by the relationships of Jesus to the lawyer and the Samaritan to the wounded man. The difference that prompted the others to pass by the wounded man was the invitational catalyst for compassionate responsive possibilities and the affirmation of the human value of both the lawyer and the stranger. Compassion does not disregard difference. It sees through difference for the sake of difference. Here Kierkegaard is helpful: "Love for the neighbor makes a person blind in the deepest and noblest and most blessed sense of the word, so that he blindly loves every human being as the lover loves the beloved." ${ }^{28}$ The neighbor does not constrain his vision to the recognized, but attends to all who are near, those who often interrupt the routine by calling for help at inconvenient moments, those who might be bloody, dirty, and different. Rather than being affronted by the startling difference of the other, it is possible to extend compassion and choose to see through the tightly wrapped linens of dissimilarity. The neighbor, the compassionate one, is attuned to difference such that regardless of his agenda, irrespective of personal regard for safety, he sees the other and is moved to compassionate care. Difference then is not a dam erected to justify the poor treatment of the stranger, but rather a bridge to compassionate ways of being-with. Luce Irigaray illuminates this regard for difference in terms of thresholds or passages between others:

On the borders of our own dwelling, thresholds will prepare a meeting with the other; thresholds on the horizon of a world allowing us to leave it and to welcome the other, thresholds also on the border of oneself, if it is possible to distinguish between the two. To build such openings 
requires from us an active undertaking but also a letting be: an economy that is too little known in our Western culture, and one that meeting with the other as other constrains us to discover, to cultivate. ${ }^{29}$

Thresholds are openings, invitations. The road to Jericho was such an opening. It was an opportunity to move between worlds. Jesus and the Samaritan showed compassion through difference because they had habituated themselves to construct openings for others wherever and whenever they appeared. Unlike the lawyer, the Samaritan was not waiting for the perfect opportunity to love a particular person, but was ready for any occasion to show compassion toward any person who crossed the threshold of their world to enter his. Compassionate care attends to the other on account of the difference between worlds.

Compassionate care for the lawyer was not merely an act of obedience for Jesus, but a recognition of the common humanity shared between him, the neighbor, and the divine. The image of the divine concealed by cloaks of difference has to do with the strangers who lay on the road, before us and also with who we as neighbors are and have been called to be. The wounded man and the lawyer do not merely represent the dire reality of the human condition - in their presence and in their need we see a beautiful conjunction of humanity and divinity and the hopeful expectation for a world not yet shared. Their relation to difference reveals a bodily comportment of compassion, a transcendent invitational hermeneutic that is cognizant of the humanity harbored within and shared between worlds. Levinas has beautifully articulated such a transcendence, writing:

$[\mathrm{M}]$ etaphysics is enacted where the social relation is enacted - in our relations $[\ldots]$. The Other is the very locus of metaphysical truth, and is indispensable for my relation with God. He does not play the role of a mediator. The Other is not the incarnation of God, but precisely by his face, in which he is disincarnate, is the manifestation of the height in 
which God is revealed. [...] It is from moral relationships that every metaphysical affirmation takes on a "spiritual" meaning $[\ldots] .{ }^{30}$

For the Samaritan, the wounded man was not some God-forsaken stranger, but instead a neighbor in whose fragility he saw himself, he saw the human condition, and he saw the possibility of a love that exceeded everyday worldly concern and calculation. And for Jesus, the lawyer was not simply a sinner who had turned away from others and from God, but rather a neighbor with whom the good news of compassion was to be shared. Jesus and the Samaritan cherished the unknown other in humility as they lived out a hopeful way of being in the world while anticipating divine invitations all along the way. Speaking to the divine wonder found in welcoming the unknown other for the mutual becoming of worlds, Irigaray writes:

Little by little the work of becoming oneself then combines continuously with that of the other in an interweaving of spaces and times where visible and invisible alternate. [...] It implies letting oneself be reached by what draws near, and accepting that, in this bringing together, the proper of a world opens up for welcoming the other. ${ }^{31}$

Irigaray points us hopeward to a world shared between people of difference, people who have learned to welcome and wait for the appearance of another, people like the Samaritan who see beyond the bruises and scars and recognize - in themselves and in the other - compassionate possibilities of care. The radical power of Jesus' Samaritan is found in the coming of the wounded man, a coming long awaited, a bewildering appearance of the divine on the road, in the dirt, covered in blood. Like the lawyer who appeared to Jesus, the revelation of the wounded man on the road to Jericho invited a response of all who would pass by.

In Jesus' care we encounter a compassion that quite literally suffers with the lawyer and in so doing radiates a transcendent beauty. Compassion, or suffering with, is 
quite different from caring alongside one another. Compassion attends to the needs and the difference of the other, leaping ahead in a radical invitation to share worlds. Compassion looks beyond external markers of dissimilarity and intentionally brings others back - to their own becoming. Compassion is the physical evidence of a hermeneutic that interprets and responds well to difference. It is the lived practice of a hope that waits and attends to the one whose arriving is an astonishing fragile paradox of the human and the divine. It is the bodily orientation in the direction of difference, on account of difference. Difference need not be diminished nor exaggerated. Compassion recognizes difference and makes way for meaningful encounters between people. Badiou articulates the universally liberating ramifications of a love similar to the compassionate care I describe, writing: "With regard to the world in which truth proceeds, universality must expose itself to all differences and show, through the ordeal of their division, that they are capable of welcoming the truth that traverses them." ${ }^{, 32}$ Here we encounter a strikingly feminist theology where difference, rather than being forsaken, is cultivated and given the space to flourish, thus making way for compassion in relation with others. Out of compassion, and thanks to the invitation made evident in our mutual difference we learn to respond to others, admitting, as Irigaray suggests, that "[t]o recognize the existence of another subjectivity implies recognizing that it belongs to, and constitutes, a world of its own, which cannot be substituted for mine; that the subjectivity of the other is irreducible to my subjectivity." 33 This compassion is the hopeful anticipation of the coming of the other, a recognition of and alliance with the shared burden of humanity, and an ability to respond to another of difference. ${ }^{34}$

\section{Compassion Within and Through Difference}

Considering this compassion in terms of a feminist hermeneutic makes evident generative possibilities for abiding in existence without succumbing to the pervasive pressures of fundamentalist ways of being-with. An invitational hermeneutic of compassion sees and does not diminish or exaggerate difference. Instead, it welcomes openings in the direction of that difference. In the presence of difference, amid the 
common fundamentalist inclinations that shape our being-with others, we see alternative responsive possibilities.

A hermeneutic that struggles within fundamentalism cannot be reserved for special moments of fleeting goodness, but must be practiced in each moment. It is a hermeneutic that proclaims, even promotes, life for all in the appearance of onecompassion is and must ever be inscribed in the world. Using the term love, Alain Badiou articulates the invitational compassion exhibited by Jesus of Nazareth in conversation with the questioning lawyer. He writes: "[W] hat is spelt out within love is that living — what is called living — comes down, not to individual interests, but to the manner in which the world is exposed to 'us' however limited this 'us' may be and however hazardous may prove its uncertain construction not from what is but from what befalls us." 35 It is a compassionate care that takes place in the everyday and reaches beyond difference, within difference, attends to the cries of the oppressed, and responds well to the difference of the other.

The effects of fundamentalism are far-reaching and extend to our most basic interactions with others of difference. Thus, compassion must be born of a discourse that speaks through—or, in Badiou's terms, "traverses"- the differences such that the universality of the truth of the love so proclaimed might be graspedOur days, like the Samaritan's, are interrupted by others who call out for care. The responsive possibility of compassion in the appearance of these others calls for the truth of our alliance with difference to be proclaimed. This proclamation occurs not in idle talk or self righteous charity, but rather in the discourse of weakness that recognizes the shared struggle of a humanity we all bear, marked by a militant, active, and often raw declaration of nothing more than the compassionate possibilities made apparent in the very presence of difference.

The characters in this story reveal an invitational hermeneutic of compassion that is both possible and necessary. The story of the Samaritan demonstrates that any love one has or professes to have is first evident in the forms of care extended to the stranger. The lawyer does not wish to care for just anyone: he has a very narrow 
community with which he concerns himself. His question is evidence of his fallenness, having become so absorbed in the stuff of his narrowly circumscribed world that he, like the Levite and the priest, does not respond well to those who fall outside his limited peripheral vision. The fundamentalist inclinations of our existence affirm and encourage the poor treatment of those outside our communities of comfort. But an invitational feminist theological hermeneutic of compassion enables us to care well for the strangers with whom we share the world. This compassion does not diminish or exaggerate difference but rather perceives the encounter as an invitation - at once mundane and extraordinary - to stop and cross the threshold between worlds in order to share in the becoming of another.

In this chapter I have described common fundamentalist hermeneutics that constrain relations between strangers. Following Heidegger's explanation of the everyday practices of the they expressed in curiosity, ambiguity, and idle talk I then argued that turning away from difference is the bodily comportment of fundamentalist inclinations. The characters in the parable of the Samaritan depicted a few of the fundamentalist hermeneutic possibilities of being-with strangers, including: distorted interpretations of difference by diminishment and exaggeration, the tendency to prefer the similar at the expense of difference, and empathetic fundamentalist practices. Following the discussion of commonplace fundamentalisms I returned to Heidegger's conception of solicitude as leaping ahead and proposed a feminist theological hermeneutic of invitation marked by compassionate care for others of difference. Significantly, fundamentalist inclinations are not reserved for strangers. Fundamentalisms are at work in every social relation. While the Samaritan's story provides a framework of response for those who fall outside our circles of concern, we must not stop with the stranger. Fundamentalist hermeneutics are structural possibilities that affect even our most intimate, familiar relations. I now turn to fundamentalisms and alternative invitational hermeneutic possibilities exhibited between family members. 
${ }^{1}$ Adam Phillips, "On What is Fundamental” in Salmagundi, vol. 162/163, Spring 2009, 69.

${ }^{2}$ Richard Kearney, On Stories (NY: Routledge, 2002), 137.

${ }^{3}$ Kearney, 140.

${ }^{4}$ Luke 10:25-27, ESV

${ }^{5}$ Martin Heidegger, Being and Time, edited by John Macquarrie and Edward Robinson. (NY: Harper \& Row Publishers, 1962), 220. “[Fallenness] This term does not express any negative evaluation, but is used to signify that Dasein is proximally and for the most part alongside the 'world' of its concern. This 'absorption in... [Aufgehen bei...] has mostly the character of Being-lost in the publicness of the "they". Dasein has, in the first instance fallen away [abgefallen] from itself as an authentic potentiality for Being its Self, and has fallen into the 'world'."

Fallenness is a weighty word. Martin Heidegger offers an ontological telling of fallenness wherein Dasein, man, is thrust into the world and is absorbed by the objects and others in such a way that he does not live 'authentically', that is he does not understand himself or others. Fallenness in this sense and for Heidegger is not a "negative evaluation" but rather is a description of how Dasein is. On the other hand fallenness represents a negative theological understanding of humanity fallen from grace who, having lost their connection with God are ever in pursuit of restoration and communion. Though at times I will be employing a theological notion of fallenness, it is to an underlying ontological fallenness that I ultimately refer.

${ }^{6}$ Heidegger, 222. With special regard to the interpretation of Dasein, the opinion may now arise that understanding the most alien cultures and 'synthesizing' them with one's own may lead to dasein's becoming for the first time thoroughly and genuinely enlightened about itself. Versatile curiosity and restlessly 'knowing it all' masquerade as a universal understanding of Dasein. But at bottom it remains indefinite what is really to be understood and the question has not even been asked. Nor has it been understood that understanding itself is a potentiality-for-Being which must be made free in one's ownmost Dasein alone. When Dasein, tranquillized, and 'understanding' everything, thus compares itself with everything, it drifts along towards an alienation [Entfremdung] in which its ownmost potentiality-for-Being is hidden from it.

${ }^{7}$ Heidegger, 213.

${ }^{8}$ Heidegger, 214.

${ }^{9}$ Heidegger, 218.

${ }^{10}$ Alain Badiou, Second Manifesto for Philosophy, translated by Louise Burchill (Malden, MA: Polity Press, 2011), 94-95

${ }^{11}$ Søren Kierkegaard, Works of Love. Translated and edited by Howard B. Hong and Edna H. Hong (Princeton, NJ: Princeton University Press, 1995), 87. 
${ }^{12}$ Kierkegaard, 87.

${ }^{13}$ Arthur Sutherland, I Was a Stranger: A Christian Theology of Hospitality (Nashville, TN: Abingdon Press, 2006), 37.

${ }^{14}$ Luce Irigaray, An Ethics of Sexual Difference Translated by Carolyn Burke and Gillian C. Gill (NY: Continuum, 2004), 85.

${ }^{15}$ Irigaray, Sharing the World (NY: Continuum, 2008), 65.

${ }^{16}$ Irigaray, An Ethics of Sexual Difference, 107.

${ }^{17}$ Heidegger, Being and Time, 158.

${ }^{18}$ Heidegger, Being and Time, 163.

${ }^{19}$ Ramsey, 32.

${ }^{20}$ Heidegger, Being and Time, 158-159.

${ }^{21}$ Rosemary Radford Ruether, Sexism and God-Talk: Toward a Feminist Theology (MA:

Beacon Press, 1993), 71.

${ }^{22}$ Irigaray, Sharing the World, 61.

${ }^{23}$ Kierkegaard, 318, 329.

${ }^{24}$ Kierkegaard, 324.

${ }^{25}$ Grace Jantzen, Becoming Diving: Towards a Feminist Philosophy of Religion (Bloomington, IN: Indiana University Press, 1999), 169.

${ }^{26}$ Irigaray, This Sex Which is Not One, 25.

${ }^{27}$ Radford Ruether, Sexism and God-Talk, 20.

${ }^{28}$ Kierkegaard, 69.

${ }^{29}$ Irigaray, Sharing the World (NY: Continuum, 2008), 9.

${ }^{30}$ Emmanuel Levinas, Totality and Infinity, translated by Alphonso Lingis (Pittsburgh, PA: Duquesne University Press, 1969), 78-79. 
${ }^{31}$ Irigaray, Way of Love, translated by Heidi Bostic and Stephen Pluháček (NY: Continuum, 2002), 132-133.

${ }^{32}$ Badiou, St. Paul, 106.

${ }^{33}$ Irigaray, Sharing the World, 1.

${ }^{34}$ Luce Irigary, Between East and West. Translated Stephen Pluháček (NY: Columbia University Press, 2002), 122-123. "We sometimes, at least partially, find this state again, I would say this state of grace, in which the spring puts us, when we are immersed in a new landscape, in an extraordinary cosmic manifestation, when we bathe in an environment that is simultaneously perceptible and imperceptible, knowable and unknowable, visible and invisible to us. We are then situated in a milieu, in an event that escape our control, our know-how, on inventiveness, our imagination. And our response to this 'mystery' is or could be astonishment, wonder, praise, sometimes questioning, but not reproduction, repetition, control, appropriation. The state that springtime, certain landscapes, and certain cosmic phenomena provoke in us, sometimes takes place at the beginning of an encounter with the other. It is in the first moments of drawing near to one another that the other moves us the most, touching us in a global, unknowable, uncontrollable manner. Then, too often, we make the other our own - through knowledge sensibility, culture."

${ }^{35}$ Alain Badiou, Second Manifesto for Philosophy. Translated Louise Burchill (Malden, MA: Polity Press, 2009), 100. 


\section{Chapter 3: Rehabilitation in a Familial Home}

\section{Overview}

Fundamentalist hermeneutics limit our interpretive responses by distorting difference. Within fundamentalist hermeneutics we often rationalize and affirm the poor treatment of others. This poor treatment is not reserved for strangers but also extends into our most intimate relations. As such, fundamentalisms are frequently exhibited within the home and enacted between family members. Kirsten Jacobson, following Martin Heidegger, Gaston Bachelard, and Maurice Merleau-Ponty, calls home the "structure of familiarity that supports and grounds our way of being-in-the-world." Home is the site where practices of care and interpretive habits are formed. It is the primary location of hermeneutic possibility - fundamentalist and otherwise. In the home we come to understand ourselves and the possibilities for being-with difference. Significantly, the family provides the relational compass for practices of care extended to others and outsiders. Difference is first understood within the confines of the sameness replicated in the familial home.

The Jewish story of Ruth demonstrates common fundamentalist inclinations of the home. It is a narrative that resonates with the contemporary experience of homemaking often constrained by the far-reaching effects of economic insecurity, displacement, and the hard fought battle of defining the family. Ruth's story is a timely articulation of fundamentalisms and of alternative possibilities for making and sharing home with others of difference.

This chapter begins by examining fundamentalist hermeneutics of the home, which is developed by considering Heidegger's conception of moods or states-of-mind that filter our interpretive possibilities. Of course not every mood expresses fundamentalist inclinations, but every mood does indicate a temporary responsive direction of our care. Protective resistance is the description I offer for the temporary responsive direction of care enacted within the home. This protective resistance is an 
alienating divisive way of being-with others that leaves us separated from difference and relationally homeless.

Following the discussion of fundamentalist hermeneutics of homemaking I then explore variations of family practice, homemaking, and the possibilities of a feminist theological undertaking of domestic life. I propose a broad and inclusive understanding of family, defined in a way similar to the one proposed by sociologist James Q. Wilson. He writes that family is "not one of several alternative lifestyles; [or] an arena in which rights are negotiated; [or] an old-fashioned and reactionary barrier to a promiscuous sex life; [and] it is not a set of cost-benefit calculations. It is [however] a commitment." ${ }^{2}$ The commitment of family depicted in the story of Ruth gives credence to the hopeful possibility of other, alternative ways of being-with difference in the home. These alternative ways of homemaking are not contingent upon biology or geography; as Allison Wier suggests, they allow us to "imagine and embrace a different dream of a better home." ${ }^{3}$ Within this broadly feminist rendering of home and family we will arrive at an invitational hermeneutic expressed in rehabilitative care for and with others of difference.

Home can be the place of recovery, a place where we, though mired in a fundamentalist mindset, are able to see other possibilities of response and tend to the needs of others for mutual recovery and flourishing. The rehabilitative home is akin to the description philosopher Kirsten Jacobson articulates in her article, "The Experience of Home and the Space of Citizenship" where the home is a stabilizing location that brings us to a place both within and beyond ourselves. ${ }^{4}$ The home is the place where family can be constructed between people of difference. The home is the primary location of our habits of care. It is the place where difference resides. And, importantly, it is the place where we, together with family, are invited and welcomed back time and again to ourselves and our senses. It is the place where the homelessness of our varied fundamentalisms is rarely experienced. Ruth's story sets the stage for this rehabilitative home, thus I begin with a brief summary of the narrative. 


\section{Narrative: Ruth}

Naomi and her husband, Elimelech, together with their two sons, Chilion and Mahlon, leave their homeland, Bethlehem, for the neighboring country, Moab. Famine in Bethlehem is the catalyst for their relocation. The Jewish people and the residents of Moab have had a long history of poor relations and mutual discrimination. ${ }^{5}$ Ten years pass and Naomi's family finds themselves comfortable in Moab; they have endured the famine and Chilion and Mahlon have chosen Orpah and Ruth, Moabite women, as wives. But their small family life in Moab would not last. Within a short period of time Elimelech, Chilion, and Mahlon died, leaving Naomi, Orpah, and Ruth widowed and childless. The tragic circumstances of Naomi's life have embittered her and she decides to return to Bethlehem. Orpah and Ruth begin the journey with her but Naomi urges them to stay in Moab, believing them to have better future possibilities in their native land. Orpah returns to Moab but Ruth refuses to leave Naomi. Thus, Ruth and Naomi travel to Bethlehem to start life anew. Naomi wears the marks of her past on her countenance-her bitterness is evident. The townspeople of Bethlehem take notice and Naomi, constrained by bitterness, chooses to be called "Mara," which means, "the Lord has dealt bitterly with me." In order to provide for their small family, Ruth begins gleaning in the wheat fields of Bethlehem, an accepted practice for the poverty- stricken in Jewish communities, and finds herself well cared for in the field of Boaz. Naomi remembers that Boaz is a relative of her late husband. This relation enables Boaz to fill the role of "kinsman redeemer"-a person responsible for rescuing and restoring the name and property of deceased family members. ${ }^{6}$ Naomi urges Ruth to go to Boaz and remind him of his redemptive right. Ruth listens to Naomi: late in the evening she goes to Boaz, finds him lying on the threshing floor, uncovers his feet, and proposes redemption and marriage. Boaz cares for Ruth but is aware of another relative who is due notice of their redemptive right. The next day Boaz goes to the other redeemer but this relative refuses to redeem Ruth, allowing Boaz to fulfill the family privilege. Ruth and Boaz are married and have a son. Joy returns to Naomi and Ruth becomes the grandmother of David, King of Israel. 


\section{States-Of-Mind: Fundamentalism as Inhabiting Moods}

While "Ruth" is the title of the narrative, the story could have just as easily been called "Naomi." It is, after all, a tale of Naomi's family, of which Ruth was a part. And Naomi is actually the character whose being-with others most clearly resonates with our own fundamentalist ways. Indeed, one of the most striking details of the story is the description of Naomi's “fallen countenance." In this section, calling upon Naomi's bitterness and joy, I will further explore the fundamentalist implications of our responsive tendencies within the home.

Heidegger's discussion of moods alerts us to the realization that our responses are far more visceral than we would like to admit. Our ways of being-with others, our practices of care, fluctuate as we find ourselves in and out of moods. Within the home we become habituated in acceptable moods and associated responses of care. It is the location where fundamentalist inclinations are encouraged and discouraged. It is the training ground for various practices of care. Though moods seem to come upon us quickly, they are rarely, if ever, completely unexpected. Fundamentalisms in the home affirm moods that offer responses to others on the basis of poor interpretations of difference. For example, Naomi's bitterness is the state-of-mind that shelters her from understanding herself and relating to others. Her mood or state-of-mind, as Heidegger calls it, is a concealed hermeneutic wherein Naomi interprets herself, others, and future possibilities of being-with. Heidegger offers assistance regarding the powerfully constraining yet exceedingly mundane situation of inhabiting moods, writing:

The mood has already disclosed, in every case, Being-in-the-world as a whole, and makes it possible first of all to direct oneself towards something. $[\ldots]$ The fact that this sort of thing can "matter" to it [Being] is grounded in one's state-of-mind; and as a state-of-mind it has already disclosed the world - as something by which it can be threatened, for instance. Only something which is in the state-of-mind of fearing (or 
fearlessness) can discover that what is environmentally ready-to-hand is threatening. Dasein's openness to the world is constituted existentially by the attunement of a state-of-mind. ${ }^{7}$

Having moods is how we are in the world. Moods, both good and bad, filter our interpretive possibilities. These interpretive possibilities are the basis of our responsive tendencies to others and objects in the world. It is significant that moods are prior to any practice of care. Moods are before, not after, thought. As such, moods in many ways reveal the hidden hermeneutic inclinations of our every encounter. Said differently, moods uncover the most basic but unapparent interpretive constructs that shape our responsive possibilities. The degree to which things come to matter to us is evidenced in the outward expression of the mood we inhabit at any given moment of the day. Moods are habitations-we are found "in" them. And, importantly, moods are clearly exhibited within the home between family members. Intimate partners, siblings, and children are most likely the first to recognize if one's countenance indicates a sour or joyful mood. If home is a familiar and stabilizing place where we come to understand being-with others, moods are the home-like places, the comfortable rooms of the self wherein we reside and respond unreflectively to others. Moods orient responsive possibilities, filter interpretive capacities, and, if reflected upon, alert us to the hermeneutic structures that foreground our encounters with others.

Though fundamentalist hermeneutics structure being-with, and though responses are tempered by our situatedness within particular states-of-mind, the changing nature of moods grants at any given moment the possibility of seeing and responding otherwise. Return with me for a moment to Naomi. Her bitterness was not the only possibility of response. Her mood was temporary, she was not without hope, and she was not wholly constrained by her fundamentalist inclinations. Later in the narrative Naomi is described as joyful. Naomi may have been caught and even comfortable in a bitter mood, but she was not permanently housed there. The home she built and the care she both extended to and received from Ruth granted her relief from the circumstances 
of her physical poverty as well as the bitterness of her soul. Here we find an important distinction concerning fundamentalist hermeneutics: moods are not fundamentalist, they simply indicate the fundamentalist inclinations at work in our practices of care and relations with others. In addition, the fluctuating nature of moods allows brief moments where fundamentalisms recede, thus inviting us to other interpretive possibilities.

\section{Fundamentalist Moods: Protectively Resistant to Difference}

Moods highlight the corporeal orientation, or responsive direction, of possibilities of interpretation. We might think of moods as the external expressions of the things we hold most fundamental. Of these fundamentals Adam Phillips writes:

Whatever is held to be of fundamental importance, of fundamental value, cannot by definition be treated casually. Indeed one of the ways we recognize the fundamental things when they turn up in conversation is that people tend to lose their composure when they talk about them. An obvious rule of thumb would be: people become violent, lose their civility, when something that is fundamental to them is felt to be under threat. $^{8}$

Whether we like it or not, the external manifestation of moods, which are intimately connected with the hermeneutic structure of our being-with, reveal the things most fundamental to us. If popular discourse is an indicator of anything, it at least points to contemporary fundamental concerns. And today, perhaps more than ever, notions of home and family are hotly debated and constantly evaluated. For example, in response to a May 2013 report compiled by the Pew Research Center ${ }^{9}$ which found that women are the sole or primary breadwinners in 4 out of 10 households in the United States, news anchor Lou Dobbs and an-all male Fox News Panel argued that, "working mothers are selfish and claimed that they are destroying the natural order." ${ }^{, 10}$ Mothers who choose to work outside the home were blamed for harming children and negatively 
affecting future generations. These women, according to Dobbs, are the cause of something gone "terribly wrong in American society." were met with responses ranging from outrage to celebration as various public personalities attempted to promote valid versions of family life. What is evident in this recent debate is that defining family and homemaking is of fundamental concern to many, many people. Moreover, deviation from the standard way of being and doing family is frequently seen as a threat to be harshly warned against. This is a common fundamentalist response to family: in an effort to preserve the family from deviation, or difference, fundamentalist hermeneutics erect interpretive and responsive borders, setting up rigid roles for acceptable practices of homemaking. This border-making response, often displayed in public with moods of anger and self-righteous indignation, is what I call protective resistance to difference.

\section{Protective Resistance: Distortions of Difference}

Protective resistance is a fundamentalist way of building and maintaining the notion of the acceptable family, which is legitimated by various fundamentalist practices of preserving sameness and protecting against foreignness, or difference. If by chance difference becomes apparent, fundamentalisms then encourage the resistance and neutralization of that difference. Fundamentalist hermeneutics of the home frequently interpret difference as a liability. Additionally, protective resistance to difference within the home is taken beyond the parameters of the home into the social sphere where fundamentalist renderings are deemed better and healthier than alternative possibilities of familial life. Suggesting that the twenty-first century home is characteristically blended, but still dominated by inflexible formulations of the acceptable family unit, Irigaray writes: "The generalized mixing in our age puts before us two possible strategies: either to go further in the reduction of the other to the same, or to recognize difference as a fundamental character of the living." ${ }^{\prime 2}$ Protective resistance to difference is a fundamentalist way of reducing the other to an imagined sameness by disregarding difference by exaggeration and then by diminishment. Within fundamentalist 
hermeneutics the family serves as the primary site of assimilation to the attitudes and practices of the they. These fundamentalist perceptions necessitate rigidly defined roles for members within the home and provide a basis from which acceptable versions of family can be promoted outside the home. Protective resistance is the public acknowledgement of those who neatly fit. Describing a similar issue at work in a privileged version of feminism Elizabeth Spelman writes:

The power to include implies the power to exclude: if feminism hadn't the power to exclude certain women before, it wouldn't make sense now to appeal to its power to include them. It's as if to say: "I've made a home here, and how I'd like to welcome you in. It's not our homeyours and mine — but my home. But you are welcome into it." [...] Welcoming someone into one's own home doesn't represent an attempt to undermine privilege; it expresses it. ${ }^{13}$

The power to include and exclude is of utmost importance within family fundamentalisms. This power is not merely reserved for specific members of the immediate biological family but extends to larger notions of how different families are legitimated in society. In Ruth's story, the other kinsman redeemer is initially receptive to offering redemption to Naomi. However, he later declines when he realizes that Ruth, the Moabite foreigner, would also be part of his family. ${ }^{14}$ Of course I am not suggesting that all families should include everyone at all times. Rather, I desire to highlight the extremely protective and exclusive nature at work in a fundamentalist conception of homemaking.

Crucially, part of protective resistance is found in the necessity of being aware of and keeping tabs on the presence of difference. It is worth noting that Ruth and Naomi made a highly unconventional home together. Moreover, it is of no small significance that everyone in town seemed to know who the women were and what they were up to. Fundamentalisms interpret and respond to differences as spectacles to be 
observed. In order to resist outsider influence, fundamentalist hermeneutics advocate vigilant awareness of difference. Consequently, the difference of the other is generally exaggerated and established as a justifiable reason for both morbid interest and exclusion. Awareness of difference is maintained by an avid promotion of sameness in contrast with the apparent differences of those foreign to the family system. Superficial curiosity allows the fundamentalist to take interest in the difference of others but only in a fact-gathering capacity. For example, those who oppose women working outside the home might endeavor to accrue basic information and perhaps even statistical data concerning families with working mothers. However, little effort would actually be given to understanding or sharing time with such a family. These fundamentalist tendencies are exhibited in various ways and degrees between people of difference. Certainly, it is not the case that every fundamentalist family runs about town loudly proclaiming the virtue of their own perceived sameness and decrying the difference of others. Nevertheless, fundamentalist hermeneutics distort interpretations of difference such that even a subtle disregard for the difference of another is continuously reaffirmed and re-inscribed first into the family, and then into the popular conceptions of acceptable homemaking.

Fundamentalist homemakers further diminish their own difference by also superficially attending to themselves. In making much of the difference of others fundamentalist hermeneutics encourage ignorance of the difference that is always a part of any gathering. In other words, having shared biology or cultural heritage never eliminates difference. I am not suggesting that differences of all types carry the same level of significance. There are differences, external markers of dissimilarity, that are more and less connected with our own self understanding, more and less obvious, and more and less potentially divisive. However, difference is a part of who we are, even if we seem to bear external and internal markers of similarity. In an essay addressing the important work of feminist Minnie Bruce Pratt, authors Biddy Martin and Chandra Talpade Mohanty speak to the trouble with feigned unity or the "repressive fiction" of sameness. ${ }^{15}$ They write: 
It is at the moment at which groups and individuals are conceived as agents, as social actors, as desiring subjects that unity, in the sense of coherent group identity, commonality, and shared experience, becomes difficult. Individuals do not fit neatly into unidimensional, self-identical categories. Hence the need for a new sense of political community which gives up the desire for the kind of home where the suppression of positive differences underwrites familial identity. ${ }^{16}$

In fundamentalist renderings of home, differences go unacknowledged and are even refused for the sake of preserving the sameness of the family. Common fundamentalisms within family often refuse to welcome and recognize differences within, because doing so would necessitate a more understanding relation to the differences of others. If difference were allowed, the sameness guarded so fiercely by fundamentalist hermeneutic responses would be called into question. The threat posed by differences would recede from practices of homemaking because difference would be a vital characteristic of the family unit. Protective resistance to difference is the way fundamentalist hermeneutics shape interpretive possibilities of family life. By exaggerating the difference of the other and diminishing the difference of the self, fundamentalisms work to construct family within strictly defined roles and promote repressive versions of homemaking based on false perceptions of shared familial identity and experience.

\section{Being Homeless}

Moods rarely disclose the reality of who or how we are by sheltering us from having to thoughtfully attend to ourselves. In this way having moods separates us first from ourselves and then from others. Moods affirm our everyday participation in the they, numbing us into beliefs and practices that further remove us from who we are. Of the character of moods Heidegger writes: 
For the most part the mood does not turn towards the burdensome character of Dasein, which is manifest in it, and least of all does it do so in the mood of elation when this burden has been alleviated. It is always by way of a state-of-mind that this turning-away is what it is. ${ }^{17}$

Moods are not all bad, and as Heidegger suggests, we are always in a mood that necessarily tempers our responsive possibilities both positively and negatively. At a minimum, moods precede our deliberate interpretations and in so doing provide a comfortable habitat of response - a habitat that is not our home, and that separates us from those whose nearness we do not fathom.

Let us return for a moment to the narrative. From Naomi's bitter vantage point all is lost and hope is gone. She is in Moab, and does not perceive herself at home. She is nearly unrecognizable both to herself and others. Naomi's bitterness points us to a sense of homelessness most evidenced in that she has become lost, even to herself. Homelessness is a vital part of fundamentalist hermeneutics. It is the way we come to accept and even rationalize distortions of difference. Importantly, the fundamentalist does not perceive her homelessness. In a passage describing homelessness in terms of the way an agoraphobic fears being away from the safety of her home, Jacobson writes:

The home for the agoraphobic is often a place of alienation insofar as even here she is always aware of the danger of her situation and, correspondingly, is removed from her surroundings to the degree that she is focused on these concerns. Forever piqued by these concerns, she is never able to experience home. [...] Rather than making a home or being-at-home, she is bound to something-something that at some level never ceases to remind her of her alienation from the outside world. In view of this, the agoraphobic fails to experience home as a balance between turning inward and turning outward, as a nexus of ingress and 
egress, of self and other. The agoraphobic — a person who has a severely troubled experience of her own home-is, as a result of this relationship, unable to be at-home anywhere. She experiences herself as an object that is alienated from her surroundings - as an object in space rather than a dweller in the world. ${ }^{18}$

The homelessness experienced as part of the fundamentalist ways of being-with others is much like the home life of the agoraphobic. The threat of difference and otherness is difficult to bear. Fundamentalist hermeneutics are interpretive constructs of busyness wherein borders are erected and rigid boundaries are designed in order to achieve a false and alienating sense of safety. Fundamentalisms alienate us from ourselves and familial others. Homelessness has little to do with physical structures, and much to do with how we find ourselves in the world. Irigaray speaks of the masculine subject in terms of exile and writes: "[T]he masculine subject is in a way situated outside himself. He is in exile from his relational being, and what he feels as familiar and near remains strange to him." ${ }^{.19}$ Exile, or homelessness is way of being in the world in which we are lost to ourselves and separated from others. As such we are constantly on the move, and busied, much like the Levite, the priest, and the lawyer in the story of the Samaritan, looking for ways to construct walls or fences: temporary buildings that assuage the ever-present inkling that we are not home, that others, though proximate, are not near. Fundamentalist hermeneutics conceal the interpretive constraints of being-with as well as the alienating nature of those constraints. We do not know or we can't quite remember how to be with others of difference because we are fearful and have forgotten how and that we must reside with our own difference. However, and happily so, what is truly hopeful about our homelessness is found in the faint reminder that we need not be homeless, that others are near, and that difference is remarkably human.

\section{Rehabilitating, Redeeming the Home: Familial "Leaping Ahead"}

Homelessness and protective resistance are not the only hermeneutic possibilities for being-with others in the world. Though fundamentalisms are common hermeneutic 
structures present in our homemaking, we are never wholly overcome by our fundamentalist inclinations. As Weir suggests, there are ways to be with others and share home that might be "less comfortable and less safe, but more truthful and less lonely. ${ }^{20}$ Certainly these other ways are uncomfortable and even risky. However, they invite us to return to ourselves and our senses and provide the means to construct families and make homes respectful of difference less inhibited by our fundamentalisms. Because fundamentalisms have been part of homemaking for so long, alternative interpretive frameworks must recover or rehabilitate our familial practices of care.

Rehabilitation is the term I have chosen to describe the invitational feminist theological hermeneutic alternative to fundamentalist forms of care within the home. To rehabilitate conveys the idea of making fit again or restoring. It is the notion that something or someone has been lost and needs to be recovered in order that the person, who is often considered ill, might live again. Rehabilitaion resonates with the home in that "habilitate" is related to habitat, or dwelling. Home is a place where we catch sight of other ways of being-with ourselves and others.

Ruth, Naomi, and Boaz demonstrate a rehabilitative practice of care within the home where recovery from the blinding clutches of fundamentalisms is possible. Ruth pursues family with Naomi, inviting her to see other possibilities of sharing and dwelling. Naomi is freed from her bitterness enough to utter words of redemption to Ruth, urging her to go to Boaz. Ruth invites Boaz to acknowledge his position and respond to her petition. In each of these cases, the practice of care, like the care extended by Jesus to the lawyer, "leaps ahead" for the other. It reminds others of their own redemptive possibilities and in so doing ultimately rehabilitates. Rehabilitation returns the other to himself such that alternative possibilities of being-with can be understood. It is a reciprocal invitation concerned with the mutual flourishing of all members of the home. Rosemary Radford Reuther discusses the reciprocal nature of redemption and liberation by writing: "We need to think in terms of a dynamic, rather than a static, relationship between redeemer and redeemed. The redeemer is one who 
has been redeemed $[\ldots]$. Those who have been liberated can, in turn, become paradigmatic, liberating persons for others. ${ }^{, 21}$ Rehabilitation is the invitational act of caring well for those who are near, those who are family. It offers the possibility of liberation for others of difference and it often begins within the home.

\section{Rehabilitation: Habitations of and for Difference}

Rehabilitation is an invitational way of homemaking, a hermeneutic of care that makes alternative ways of being-with come to the foreground of understanding. This rehabilitative care is similar to the way in which Alison Weir describes Minnie Bruce Pratt's definition of love as "creating a positive identity in connection with others. [...] [S] ustained by a desire to expand the circle of self, loosen the constrictions of fear, and escape the loneliness of separation." 22 Ruth and Boaz are faithful, steadfast, valorous people who partner together and create a family of difference and respect. They are not constrained by dominant models of home and family. They do not hide from difference but rather evince a hospitable generosity that is evident in their ways of being-with others of difference. One of the striking notions that Ruth helps us see is that family can be and often is the result of a choosing, an invitation. Once again Weir is helpful; she calls the freedom of the home "not a withdrawal into self-ownership, but an expansion of oneself in relationship. [...] [N]ot leaving the home, but expanding to find a home."23 Contrary to fundamentalist renderings of the home where members protect their sameness from the perceived threat of difference, their home was a careful practice in finding and making home with others of difference.

In the rehabilitated house, difference becomes the catalyst for choosing and making home. This, I believe, is the direction Irigaray points toward in her discussion of the home as a site of mixing or blending. ${ }^{24}$ Irigaray describes a home not overtaken by the fundamentalist desire to resist difference. This family is made together, on a journey with difference. Rather than protecting themselves from difference in a fundamentalist resistance of the other, the members of this home protect, or safeguard the difference that invites them together. Irigaray helps us understand that the home is not merely, if at 
all, a structure of spatial proximity. To this end Irigaray writes, "Between one and the other a micro-culture is set up. It can become the leaven for a universal culture that keeps alive the energy of each one as well as that of the relation between the one and the other." ${ }^{25}$ Home is more than the spatial constraints of buildings, neighborhoods, and cities - more than external and often divisive markers of difference such as ethnicity and religious affiliation. A well-constructed home is the intersection, not the denial, of these differences. Irigaray's language is wonderfully resonant with the home that was shared between Ruth and Naomi and later extended to include Boaz. Ruth's refusal to abandon Naomi is foundational to the construction of the home-space between them. The home of Ruth and Naomi was unconventional in at least two ways. First, they constructed a home not dependent on geography or biology—sameness and physical structures were not the primary tenets of the home they shared. Second, they made a family without men; they were two women living with and caring for one another. Ruth and Naomi constructed a dwelling space on the foundation of their difference. Though outcasts and strangers, the home they shared invited them away from the constraints of fundamentalist inclinations and propelled them toward other possibilities of being-inthe-world. In their unusual home we witness the beginning of a partnership that would refound their whole family - a family that would in many ways defy the traditional and dominant models of their day.

Contrary to the fundamentalist home of protective resistance, the rehabilitative home is marked by an invitational awareness to difference that cultivates and tends to the mutual flourishing of all who dwell therein. Irigaray speaks of this dwelling space between as a place where human becoming is fostered as we turn and orient ourselves in the direction of the other. For Irigaray, though we have not yet created such a place, the space between is characterized by hospitality, respect, and openness to others of difference:

There is not yet a sharing of Being, which presupposes opening oneself to a becoming to which we agree to be attentive to listen. Not merely an 
individual becoming in a horizon already defined by a culture, a language, a people. But a human becoming that calls into question what has already happened to humanity, and that allows and clears the way for new perspectives on Being, with new obligations and possibilities for human blossoming. ${ }^{26}$

The home as a space marked by openness to the other of difference is observed in Ruth as she turns toward Naomi and Bethlehem - a foreign land and people. Ruth's kindness to Naomi is widely known and seems to extraordinarily contradict the common perceptions the people of Bethlehem had of their Moabite neighbors. It is important to note that Naomi does not quickly accept Ruth's kindness. Ruth urges, presses upon Naomi and only then do we find Naomi turning with Ruth toward Bethlehem. As Naomi dwells with Ruth and the home between them is built, Naomi becomes free not only to heal, but also to see other possibilities for herself in the world with others. When Naomi decides to leave Moab she tells Ruth and Orpah to return to "the house of their mothers. ${ }^{, 27}$ Though this directive carries much weight with regard to the role of the mother in Jewish culture, Ellen Davis suggests that Naomi is implicitly acknowledging what she perceives as her own inability to $b e$ a mother. ${ }^{28}$ As the story progresses and their home is constructed, Naomi attends to her own becoming in her turning toward Ruth. Naomi regains her ability to mother as she learns to care for Ruth, her Moabite, foreign, daughter-in-law. Ruth offers Naomi the opportunity to glimpse and accept another way of being-with, another hermeneutic wherein others of difference can be known and welcomed as family. Ruth does not allow Naomi to wallow in loneliness and bitterness. She invites Naomi to attention and to the recognition that family can be and often is made of one's choosing as participants learn to respond and respect the inherent difference of the members of the household. They are companions and they are family. They struggle together in loss. In their turning, each to the other of difference, their home becomes a remarkable space where the weight of the burden of their existence is shared, and each is free, in Irigaray's terminology, to "blossom." 
What is beautiful about the home of openness to the other that we witness between Ruth and Naomi is that their home space is eventually extended to include Boaz. And in Boaz we observe further possibilities for dwelling together. Turning toward the other of difference is what distinguishes Boaz from the other kinsman who fails to redeem Ruth and Naomi. Openness, or turning toward others of difference, is a way of life for Boaz as for Ruth. It is not merely a rare but laudable occurrence; rather, it is how they dwell with others, and the foundation of the home they construct and share with one another. Ruth's reputation as a foreigner who has made a habit of steadfast openness to the difference of her embittered mother-in-law lays the groundwork for Boaz to reciprocate in kind. As they make a habit of turning toward the other, as they demonstrate invitational rehabilitative care for each other, they are free to recognize and respond to the other with liberating possibilities for being-together in the world. Ruth and Boaz find mutual redemption in their willingness to turn toward each other. Ruth invites Boaz to action, Boaz reciprocates, and a home is built and shared. Significantly, rehabilitation is a way of care that invites difference within the home. It is a practice of invitational recovery that shares, respects, and responds to those with whom we dwell for mutual liberation. The rehabilitative care exemplified in the narrative of Ruth is a steadfast orientation of care toward others of difference. Though the narrative begins in tragedy, it ends in joy and hope, not because of the national heritage that Ruth becomes part of, but because we, along with Ruth, Boaz, and Naomi, come to the understanding that homemaking and sharing are not limited to the construction of permanent boundary lines of sameness. Naomi's bitterness and eventual joy remind us that fundamentalisms, though prevalent, are not the only ways of beingwith others. Ruth points us toward hope because she, Naomi, and Boaz stand in contrast with definitions of home and family that have long limited our ways of being-with and seeing others. Their versions of homemaking demonstrate that family is often much more than what the fundamentalist renderings and conventional models seem to suggest. 
The fundamentalist hermeneutics that shape our individual relationships frequently make their way into our public ways of being-with others. And, fundamentalism is rarely, if ever, confined to the private spaces of our lives. As such, fundamentalist distortions of difference that are prevalent in private are frequently affirmed and practiced between people in society. The following chapter addresses common fundamentalisms that inhibit interpretive and responsive possibilities in the relational contexts of the social sphere. 


\footnotetext{
${ }^{1}$ Kirsten Jacobson, "The Experience of Home and the Space of Citizenship," in The Southern Journal of Philosophy, vol 48, no. 3, September 2010, 220.

2 James Q. Wilson, "The Family-Values Debate," in Commentary Magazine, vol 94, no. 5, April 1993, 29.
}

${ }^{3}$ Allison Wier, "Home and Identity: In Memory of Iris Marion Young," in Hypatia, vol. 23, no. 3, July-September 2008, 9.

${ }^{4}$ Jacobson, "The Experience of Home and the Space of Citizenship," 228-229.

${ }^{5}$ Ruth's Moabite ethnicity is of crucial significance to the story, not just because it sets her apart as other than Jewish but because the Moabites had long been banned from entering Jewish communities of worship. Ruth was not merely foreign; she was part of a people group often perceived as untrustworthy, disingenuous, and inhospitable enemies to the house of Israel. The strain between Moabites and the Jewish people began when Moses led the Israelites through Moab on the way to Canaan. Out of fear, instead of allowing peaceable passage Balak, the king of Moab, refused the children of Israel and summoned a prophet, Balaam, to curse the Israelites. As a result of this unkind rejection the Moabites were forever excluded from taking part in the Jewish community. See Deuteronomy 23:3-6: "No Ammonite or Moabite may enter the assembly of the Lord. Even to the tenth generation, none of them may enter the assembly of the Lord forever, because they did not meet you with bread and with water on the way, when you came out of Egypt, and because they hired against you Balaam the son of Beor from Pethor of Mesopotamia, to curse you. But the Lord your God would not listen to Balaam; instead the Lord your God turned the curse into a blessing for you, because the Lord your God loved you. You shall not seek their peace of their prosperity all you days forever." (See also Numbers 21:2124:25).

${ }^{6}$ Gen 48:16; Ex 6:6; Lev 25:47-55, 27:9-25, 35:9-34; Num 5:8

${ }^{7}$ Heidegger, Being and Time, 176.

${ }^{8}$ Adam Phillips, "On What is Fundamental" in Salmagundi, vol. 162/163, Spring 2009, 63.

${ }^{9}$ http://www.pewsocialtrends.org/2013/05/29/breadwinner-moms/

${ }^{10}$ Gina Messina-Dysert, "Selfish Working Mothers Destroying the Natural Order? http://feminismandreligion.com/, June 5, 2013

${ }^{11}$ Messina-Dysert, "Selfish Working Mothers Destroying the Natural Order?"

12 Irigaray, Between East and West from Singularity to Community. Translated by Stephen Pluháček.(NY: Columbia University Press, 2002), 139. 
${ }^{13}$ Elizabeth W. Spelman, Inessential Woman: Problems of Exclusion in Feminist Thought (MA: Beacon Press, 1988), 163.

${ }^{14}$ Ruth 4:1-6

${ }^{15}$ Biddy Martin and Chandra Talpade Mohanty, “Feminist Politics: What's Home Got to Do with it?" in Feminist Studies/Critical Studies edited by Teresa de Lauretis (Bloomington, IN: Indiana University Press, 1986), 204-205.

${ }^{16}$ Biddy Martin and Chandra Talpade Mohanty, 204.

${ }^{17}$ Heidegger, Being and Time, 174.

18 Jacobson, "The Experience of Home and the Space of Citizenship," 234 and 236.

${ }^{19}$ Irigaray, Sharing the World, (NY: Continuum, 2008), 103.

${ }^{20}$ Allison Wier, "Home and Identity: In Memory of Iris Marion Young," 6.

${ }^{21}$ Rosemary Radford Ruether, Sexism and God-Talk: Toward a Feminist Theology (MA: Beacon Press, 1993), 138.

${ }^{22}$ Allison Wier, "Home and Identity: In Memory of Iris Marion Young,” 11.

${ }^{23}$ Allison Wier, "Home and Identity: In Memory of Iris Marion Young," 16.

${ }^{24}$ Irigaray, Between East and West from Singularity to Community.141.

${ }^{25}$ Irigaray, Sharing the World, 57.

${ }^{26}$ Irigaray, Sharing the World, 23.

${ }^{27}$ Ruth 1:8

${ }^{28}$ Davis, Who Are You, My Daughter?, 17 


\section{Chapter 4: Courage in the Social Sphere}

\section{Overview}

In earlier chapters I turned to Heidegger to describe fundamentalist complicity in the common attitudes of the they. This conception helped to elucidate the stifling consequences of our uncritical participation in average ways of being-with that level down our interpretive and responsive inclinations. Within the they assimilation is encouraged in both thought and practice. Heidegger's they granted early insight into the public implications of various fundamentalist hermeneutic possibilities. In this chapter I move from the individual relational expressions of fundamentalist hermeneutics into the larger, public fundamentalisms, carried out in the social sphere. The social sphere is the gathering of difference and the place where similarity is celebrated. Much like Heidegger's they, Hannah Arendt describes the assimilating and often negative power of the social sphere, writing: "Whether a nation consists of equals or non-equals is of no great importance [...], for society always demands that its members act as though they were members of one enormous family which has only one opinion and one interest." Arendt's description resonates in important ways with fundamentalist hermeneutics that distort difference in favor of the collective pursuit of sameness. In such a society difference hinders community participation by setting up divisive boundaries between those called members and outsiders, foreigners and nationals, or strangers and neighbors. External particularities thus constantly affirm and reaffirm fundamentalist practices of care between members of the social sphere. In a similar way Alain Badiou also speaks to the troubling matter of what he calls "communitarian identities" in the social sphere which use external markers of difference in order to reciprocally "maintain and mirror" themselves in social relation with the other. ${ }^{2}$ He writes:

Each figure gains its rotating legitimacy from the other's discredit. Yet at the same time, each draws on the resources of the other, since the transformation of the most typical, most recent communitarian identities 
into advertising selling points and salable images has for its counter part the ever more refined competence that the most insular or most violent groups display when it comes to speculating on the financial markets or maintaining a large-scale arms commerce. ${ }^{3}$

Badiou articulates a social space where difference is present and always exaggerated such that it becomes a stumbling block to generative formations of community. Communitarian identities get in the way and are constantly called upon to simultaneously legitimate themselves and discredit the other. Badiou's communitarian identities are thus comparable to the fundamentalist distortions of difference I will examine that are present in the relational context of the social sphere.

In order to address societal fundamentalisms I will first explore Heidegger's conception of Enframing to propose that the social sphere is characterized by generalizing difference and objectifying others. Enframing will be understood as a way of revealing that predetermines the public value of another on the basis of external markers of difference. Upon determining value and use, Enframing works to order and categorize people of difference into groups of similarity such that their difference is both exaggerated and diminished - which is the interpretive distortion of the fundamentalist hermeneutic. Enframing that begins with the generalization of difference frequently leads to the objectification of others, and ultimately alienation from the self and the others with whom public spaces are meant to be shared. Following the discussion of the Enframed social sphere, in order to highlight the prevalence and danger of the fundamentalist hermeneutic, the widely accepted practice of misogynist fundamentalism will be examined.

Importantly, the hermeneutic structure of being-in-the-world leaves open many interpretive possibilities. Enframing need not be restricted to fundamentalist interpretations or practices of care. Enframing as a way of revealing brings us ever to the "brink of possibility" and interpretive response. I will then call upon a feminist 
theological hermeneutic to propose "concernful reticence" and "courage" as two alternative interpretive possibilities for the social sphere.

The story of the Jewish heroine Esther is the narrative lens through which I will address the public perception of difference and the alternative interpretive possibilities for being-with in the social sphere. Within Esther's story we will witness fundamentalisms between strangers, family members, and also in the larger community. The king's advisor Haman's hatred for Mordecai, a Jewish stranger, leads him to rashly advocate genocide. Haman and his wife demonstrate a fundamentalist mindset as they constantly plot to protect their family and homeland from the Jews. And, Jewish and non-Jewish people are set at odds with one another on the basis of external, cultural, and ethnic differences. But, and importantly so, the characters of Esther, Mordecai, and Vashti point to alternative ways of being-with others that give hopeful indication of our own interpretive possibilities. The final sections of the chapter explore what Mary McClintock Fulkerson and Sheila Briggs have described as a hopeful "non-imperialist, non-essentialist" feminist theological hermeneutic within the social sphere that has been unhinged from hegemonic strategies. ${ }^{4}$ The characters in Esther's story point to an invitataional hermeneutic grounded in courage and reticence that offers generative possibilities for being-with others of difference in our shared social spaces. I begin with a short summary of the narrative.

\section{Narrative: Esther}

Artaxerxes, King of Persia, throws an extravagant party. The celebration lasts 180 days. The Queen, Vashti, also gives a feast for the women of her court. During these days of revelry the King and his guests fill themselves with a seemingly limitless supply of food and wine. The men become drunk and the King calls upon Vashti for entertainment. He wants her to present herself as a spectacle of beauty to the drunken men. Vashti refuses. Artaxerxes is outraged. His advisors suggest that Vashti be deposed of her position as queen, a suggestion that Artaxerxes carries out. After the party is over and the guests have all gone, Artaxerxes, upon awakening from his 
drunken stupor, remembers Vashti and what had been done. The King is distraught and finds himself in need, once again, of a Queen. He calls upon his advisors for support and it is decided that a beauty pageant will be held to search for the woman who would take Vashti's place as queen. A call goes out from the kingdom beseeching eligible virgins to enter the contest, join the King's harem, and possibly become the Queen of Persia. The eligible women would spend one year in the palace for beautifying, six months with oil and myrrh, and six months with spices and ointments. ${ }^{5}$ Each contestant would be summoned for an evening with the King after which the Queen would be chosen.

Esther is a beautiful Jewish woman who, after the death of her parents, was taken in by her uncle Mordecai. Esther is called to participate in the contest and at her uncle's suggestion does not reveal her Jewish heritage. Esther wins the King's favor and is chosen as Queen. Shortly after her induction as Queen, her uncle Mordecai, accidentally uncovers an assassination plotted against the King. Mordecai brings the plot to Esther's attention and Esther warns the King. The details of the plot are recorded in the chronicles of the kingdom.

Artaxerxes' kingdom extends from India to Ethiopia and spans 127 provinces. Many different people, including thousands of Jewish people, make up the expansive government. Haman the Aggagite is one of the prominent advisors to the king. Haman is second in command and handles many of the details of the kingdom on behalf of the King. He is trusted by the King and generally well liked by the people, but Haman loathes the Jewish people. Haman also thinks very highly of himself and in the course of his work decides to invoke a law requiring all people to bow before him. Everyone except Mordecai receives this law with obedience. Mordecai's Jewish faith does not allow him to bow before any man and he refuses to prostrate himself before Haman. Mordecai's insurrection angers Haman and in his fury and out of his deep-seated hatred, Haman makes a proposition to the King to annihilate the Jews. The King trusts Haman and agrees. Mordecai gets word of Haman's plan and calls upon Esther to go before the king on behalf of the people. Though Esther has not been summoned to the King, at the 
risk of her own life, she goes to the King for her people. The King, happy to see her, extends his scepter to her and desires to know the purpose of her unexpected appearing. Esther invites the King and Haman to a dinner party. The King accepts her invitation and calls at once for Haman. The evening is lovely and the king, knowing there must be more to Esther's request than a dinner party, asks Esther to reveal her request. Esther invites the men to a second dinner party. The king agrees and Haman is elated. But Haman's merriment only lasts a short time, because on his way home he sees Mordecai and is reminded of the burning hatred he has not only for Mordecai, but for all Jews. When Haman arrives home his wife suggests that a gallows be built upon which Mordecai might be hanged. This idea delights Haman and the gallows is built.

That same night the King finds himself having difficulty sleeping and calls for the records of the kingdom to be read aloud. During this late-night reading the assassination plot uncovered by Mordecai is brought to the King's attention. Artaxerxes realizes that Mordecai has not been rewarded for his loyalty. Haman enters the palace to inform the king of his plan to hang Mordecai but the King has other, more pressing business for Haman. The King asks Haman to help him decide what to do to show honor for a man whose service is appreciated. Haman, thinking this to be himself, suggests that the appreciated man be adorned with royal robes, given a royal horse, and led through the capital with people shouting, "So is done for the man who delights the king!" Artaxerxes loves this idea and orders Haman to do it for Mordecai. In the evening Haman and the King go to Esther's second banquet. Esther pleads for her life and charges Haman with the crime of planning the genocide of her people. The king orders Haman to be hanged on the gallows that had been prepared for Mordecai. After Haman is executed Artaxerxes agrees to Esther's urging and makes concession within Persian law for the Jewish people to defend themselves and their property against anyone attempting to go through with Haman's plan to annihilate them. Esther's people are saved, Mordecai is promoted to fill Haman's position, and the Jewish people to this day celebrate the feast of Purim in remembrance of Esther's bravery and Haman's failed plot. 


\section{Heidegger's Enframing: Objectified Others \& Generalizing Difference}

Fundamentalisms have been explained as a hermeneutic structural possibilities for being-with others in the world. They are the common ways of interpreting and responding to others of difference and this commonality is constantly affirmed by the popular attitudes of what Heidegger calls the they. Fundamentalist hermeneutics maintain a distorted interpretation of others by simultaneously exaggerating and diminishing difference. As Heidegger's conception of moods helped to elucidate the primary interpretive construct within the home, his notion of Enframing provides a rich understanding of the fundamentalisms frequently affirmed in the social sphere. Though Heidegger was specifically writing to address the conciliatory nature of the technological age - calling technology a "way of revealing" that discloses and opens possibilities of understanding - fundamentalisms are also ways of revealing, hermeneutics, that are intimately connected with our varied ways of being in the world with others. ${ }^{6}$ Here Heidegger describes Enframing:

Everywhere everything is ordered to stand by, to be immediately at hand, indeed to stand there just so that it may be on call for a further ordering. Whatever is ordered about in this way has its own standing. We call it the standing-reserve. [...] The essence of technology lies in Enframing. Its holding sway belongs within destining. Since destining at any given times starts man on a way of revealing, man, thus under way, is continually approaching the brink of the possibility of pursuing and pushing forward nothing but what is revealed in ordering, and of deriving all his standards on that basis. ${ }^{7}$

Enframing halts and orders interpretive possibilities such that appropriate ways of being-with have been prearranged in advance of our every encounter. Having been so ordered, the things and others in the world are firmly, though not permanently, placed in 
a standing reserve. Consequently, others are reserved for use-for predetermined or predestined roles and purposes. Fundamentalisms Enframe, concealing the differences of others such that people appear not in their distinction but as preordained representatives of utility. Like the essence of technology, fundamentalisms categorize others according to their use and place them in a holding pattern awaiting the call of duty. Fundamentalist inclinations see others of difference not in their particular variations, but in generalizations and caricature. People of difference are all the same. Importantly this false perception of sameness extends into the relations within the social sphere.

Esther's story bears witness to the violent possibilities of fundamentalist Enframing most poignantly through Haman's hatred of the Jews, which led to the kingdom-approved annihilation proposal. To Haman, Mordecai's Jewish heritage was a simple category in which all Jews could be first recognized and then ordered based on a shared semblance of external and cultural similarities: the Jews were all Jews. And, importantly, the Jews were not, could not, be like Haman. Enframing fundamentalist hermeneutics see and speak of people in groups of difference as they, rather than singular others or each. Others appear as representatives of categories of difference rather than singular encounters between people of remarkable distinction. The fundamentalist search for sameness is much like the problem of essentialist notions of womanhood. Describing essentialist versions of woman within feminist discourse, Elizabeth Spelman writes: "[E]ssentialism invites me to take what I understand to be true of me "as a woman" for some golden nugget of womanness all women have as women; and it makes the participation of other women inessential to the production of the story. How lovely: the many turn out to be one, and the one that they are is me." Others are either just like me, or nothing like me - either way, our interpretive possibilities have been Enframed, predestined, long before any real exchange in the social sphere. 


\section{Fundamentalism and Accepted Misogyny}

If the relevance of Esther's story and the apparent fundamentalism practiced in the social sphere seem out of touch with the reality of the contemporary doctrine of tolerance, let me assure you, fundamentalist Enframing is not a thing of the past. Fundamentalisms are subtle, dangerous, trans-historical structural possibilities of beingwith others. However, fundamentalist hermeneutics are concealed, and are frequently accepted as part of the slow process of advancement for particular marginalized groups. On the basis of external difference, various groups of people are Enframed, placed in a standing reserve, objectified, and poorly treated as subjects of possession by the others with whom the social sphere is meant to be shared. Significantly, this objectification is rarely named as such and is part of the accepted and popular possibilities of interpretation.

One of the most obvious instances of this brand of popular objectification can be observed in a practice I call the accepted misogyny of the social sphere. In a recent essay titled, "The War on Men," author Suzanne Venker claims there is a war on men and it's the fault of aggressive angry women. Venker arrives at this conclusion by way of a problematic interpretation of historical and statistical data, and as would be expected, the "facts" seem to confirm her argument. Venker's article reveals the Enframing nature of fundamentalisms that run deep in the fabric of the social sphere. Lamenting that men have "nowhere to go," she asks, "[W] hat if the dearth of good men, and ongoing battle of the sexes, is — hold on to your seats —-women's fault?" "After a barrage of female bashing, Venker calls women to "look in the mirror," "return to their femininity," and allow men the chance and the space to stop hating them. ${ }^{10}$ The roles that women want do not fit within the prearranged categories of the social sphere. In an effort to promote a return to the misconceived and faulty but popularly approved notions of femininity and masculinity, Venker at once affirms the poor treatment of her own gender and blames women for their objectified status. Venker is not alone in her misogynist perceptions. In addition to her short essay, she has successfully published three bestselling antifeminist books. ${ }^{11}$ Additionally, an abridged version of Venker's 
essay, published at foxnews.com received over two hundred thousand Facebook "likes," which speaks to the widespread acceptance of her work.

Venker espouses a message of hatred that is indicative of Enframing fundamentalist hermeneutics that generalize, objectify, and then poorly care for others of difference. The social sphere is often the place where objectified difference gets affirmed and promoted. Differences such as gender are first generalized such that the sameness of gender trumps any other significant differences. Following this generalization, women and their differences are then objectified based on their misperceived sameness. This objectification assigns public value to women based on their ability to perform specific roles in line with inflexible and essentialist notions of femininity. Of course I am not suggesting that all fundamentalists are misogynist, but that acceptable misogyny is merely one interpretive possibility within fundamentalist Enframing. The objectification of women that is practiced by many misogynist fundamentalists is but one of the ways of being-with enacted in the social sphere. As such the misogynist fundamentalist poorly relates with others as if their varied differences were either liabilities or marketable assets. Where misogyny is accepted, hatefulness is neither extraordinary nor offensive, thus the misogynist merely maintains the fundamentalist status quo.

A brief return to Esther's narrative further demonstrates the pervasive, dehumanizing fundamentalist hermeneutics manifest in the commonplace practice of accepted misogyny. The story begins, not with Esther, but with Vashti. Vashti, having denied her drunken husband and his guests the visceral pleasure of objectifying her, is treated with contempt and thus makes possible Esther's rise to the throne. But Vashti's refusal has consequences that reach far beyond herself and her position. The king and his advisors treat Vashti's rebellion and her being deposed as examples for the whole kingdom. They cannot imagine a world where women are free to refuse their husbands. In Carey Moore's Anchor Bible Commentary on Esther, we learn that in addition to Vashti's removal, letters were composed in all the languages of the kingdom and dispatched to all 127 provinces, "[t]o the effect that every man should be master in his 
own home and say whatever suited him."12 While it could certainly be argued that these moments of objectification were merely part of the specific historical and social context of the narrative, I would argue that these events are indicative of intensely contemporary fundamentalisms. The women of the kingdom were treated as possessions, a way of being-with that was modeled by the king and maintained by the male subjects of the kingdom. The women had to be managed and controlled by their male masters. The women were different and their difference was perceived as a threat that required suppression and containment. In Vashti's refusal and Artaxerxes' response, we witness a striking impediment of fundamentalisms: others of difference become possessions to be categorized and manipulated. This particular enactment of fundamentalist possession is further carried out in the forcible acquisition of female contestants for the throne. From the start of the story we come to understand the fundamentalist hermeneutics to commonly interpret and treat others of difference as objects of possession. Vashti was a woman and was beautiful, but she was not obedient, she had no use, thus she had to be traded.

\section{Fundamentalism: Accustomed to Alienation}

Fundamentalisms in the social sphere are outwardly manifest in the desire to establish and maintain a distorted, common perception of difference, where others can be stored away, managed and available for use. In a harsh rendering of the masculine subject, who's being-with is constrained in similar ways to the fundamentalisms I describe, Irigaray writes:

Not cultivating what he really is, not even recognizing it, has man not been unfaithful to his destiny - to take up a word dear to the sages of the West?[...] But the masculine subject has also left behind him nature, woman, and even children. His culture amounts to a sort of monologue more and more extrapolated from the real, unfolding itself parallel to this real in order to carve it up and thus dominate it. This is not very respectful 
of the other. And it does not lead to happiness. Neither does it correspond to a human wisdom, but rather to an exile surrounded by fortifications where man takes shelter. ${ }^{13}$

Irigaray depicts a masculine subject whose every utterance is unfaithful to himself and others. His language is a repetitive monologue that works to manipulate and dominate. He is alienated from women, nature, children, and ultimately himself. He sets up shelters in language and practice. His ways of being-with are not grounded in the real but in an imagined space of fabricated sameness and control. Though Irigaray describes a masculine subject, her words ring true for fundamentalist subjects as well.

Fundamentalist hermeneutics order interpretive possibilities such that difference can be managed and contained which leads to alienation on at least two accounts. First, fundamentalisms alienate us from difference. Importantly, fundamentalisms often welcome this separation because skewed perceptions of difference typically encourage division. However, fundamentalisms are alienating on a second relational level as well. As fundamentalists work to maintain exclusionary ways of being-in-the-world, we are often unwittingly alienated from ourselves. The protective measures taken to ward off the unwanted difference of others also affects how we come to understand ourselves and our own difference.

Alienation is a great danger of the Enframing nature of fundamentalist hermeneutics within the social sphere. Of this danger Heidegger writes:

Yet when destining reigns in the mode of Enframing, it is the supreme danger. This danger attests itself to us in two ways. As soon as what is unconcealed no longer concerns man even as object, but does so, rather, exclusively as standing-reserve, and man in the midst of objectlessness is nothing but the orderer of the standing-reserve, then he comes to the very brink of a precipitous fall; that is, he comes to the point where he himself will have to be taken as standing-reserve. [...] Man stands so decisively in 
attendance on the challenging-forth of Enframing that he does not apprehend Enframing as a claim, that he fails to see himself as the one spoken to, and hence also fails in every way to hear in what respect he eksists, from out of his essence, in the realm of an exhortation or address, and thus can never encounter only himself. ${ }^{14}$

Heidegger alerts us to the possibilities of Enframing. Enframing, which initially works to order and mange the others and objects in the world, eventually reaches outward and into the social sphere. Once Enframed, everyone is placed in standing-reserve and alienated from each other. The danger of this alienation is that Enframing fundamentalist hermeneutics reframe the social sphere as standing reserve.

The social sphere as standing reserve thus constrains encounters with difference and limits interpretive possibilities on the basis of misperceived value. In a social sphere driven by exchange, where human value is determined by objectified others, differences and others are constantly evaluated and managed for future worth. Here we again witness the fundamentalist distortion of difference. Irigaray offers a poignant description of the contemporary understanding of the self and other that is closely related to the alienation to which the fundamentalist succumbs, writing: "[T]he risk exists of knowing a thousand things, of finally reducing ourselves to an effect of acquisition of knowledge, but of no longer knowing anything about who $I$ am, who you are, who we are." ${ }^{15}$ In a similar way fundamentalist hermeneutics within the social sphere distort perceptions of difference and place us in standing reserve - estranged from each other and without understanding of the self.

\section{Enframing: The Brink of Possibility}

It is crucial to understand that Enframing is a way of revealing; it is a hermeneutic wherein multiple interpretive possibilities are available. Heidegger claims that the destining character of Enframing "sets man on a way of revealing $[\ldots]$ continually approaching the brink of possibility." 16 Though the social sphere is ordinarily restricted 
to an alienating and objectifying fundamentalist standing reserve, fundamentalisms are not the only way of being-with others in community. The hermeneutic structure of being-in-the-world places us ever on the precipice of possibility. Said differently, we are always on the brink of other ways of being-with.

Like the Samaritan's compassion for the stranger and Ruth and Naomi's rehabilitative way of establishing and maintaining family, Vashti, Mordecai, and Esther exhibit a quiet courage and concernful reticence that extends outward into the social sphere. All of these characters act both for themselves and for the sake of their people. Vashti's refusal connects her with the women of the kingdom. Mordecai does not bow and thereby finds common ground with his brothers and sisters devoutly adhering to Jewish law and custom. Esther's resolve to go and speak to the king supports Vashti's initial resistance, giving the women of the kingdom another model of liberation from the constraining regulations of the culture and the empire both in public and private spaces. She also makes possible the salvation of all Jewish people. As Vashti, Mordecai, and Esther unsettle the tradition, they become what Irigaray has called "militant[s] for the impossible." Irigaray's call to the impossible is neither utopian nor unbearable. Her impossible might be thought of as a hopeful and mutually arduous struggle in the creation of a "rationality, civility, culture and love that remain to be built" $" 18$ between worlds of difference. This impossible is future oriented and necessarily upsets traditional conceptions of being-with others. Vashti, Mordecai, and Esther's defiance demonstrates a similar orientation, which brings hope and opens the door to the seemingly impossible salvation of their people. And, more importantly, their courageous and reticent defiance in each instance is an external manifestation of other ways of being-with others.

\section{Concernful Reticence}

The Enframing fundamentalisms of the social sphere are different from the fundamentalisms exhibited on an individual level. For example, by way of conversation the individual might be able to consider better possibilities of being-with others. But the 
social sphere is made of collectives who are not as readily convinced nor as apt to have a conversation as individuals. It is difficult to persuade a collective and rarely do we find ourselves in a position to affect change on such a large scale.

However, here in the seeming absence of our own power, we find the makings of invitational alternative ways of being-with difference. Namely, public recovery begins with personal decision. Esther's story is not necessarily about a racist politician who plots genocide. Nor is it just about a queen who saves her people. The narrative points to small subversive choices made by people who could imagine things otherwise. Being-with others in the social sphere is a matter of recognizing fundamentalist inclinations and having the wherewithal to leap ahead with and for others one by one. In Esther's story we find alternative possibilities for sharing the world with people of difference.

One alternative interpretive possibility for being-with others in the social sphere is what I have called "courageous, concernful reticence." Concern is the way of beingwith others that 'leaps in' or 'leaps ahead' toward understanding ${ }^{19}$ In previous chapters concern was witnessed in Jesus' compassionate conversation with the lawyer and in Ruth's rehabilitative construction of familial relationships. Concernful reticence is an invitational engagement with and for the sake of others. ${ }^{20}$ It is the quality of beingwith that frees us to understand other ways of sharing and making community with difference. In other words concernfulness invites us to catch sight of who we are and who we can be. It is the invitational hermeneutic in which fundamentalisms and alternative interpretive possibilities can be revealed.

The word "reticent" suggests restraint, reserve, and silence. It is important to note that the reticence I propose is not a forced silence, or even a silence in the face of danger or oppression. Instead, reticence is similar to the Greek notion of kairos, which is the understanding and seizing of the opportune moment for a particular utterance or action. Reticence is a purposeful quietude that waits and expectantly looks for opportunities to speak well with and for others. It is a way of being-with in order to subvert and destabilize the fundamentalist structures of the social sphere. Grace Jantzen 
describes a similar action for feminist theologians, writing: "There is no other place to start from than the language and cultural symbolic which we inhabit, but by 'inhabiting them in a certain way', self-consciously and with intent to subvert, new possibilities can open up." ${ }^{21}$ This reticent silence is not oppressive. It is liberative, and it is a choice. It is a way of being-with that bears witness to other possibilities of sharing the world and it works within the constructs of the common interpretive structures in order to effect change from within. It is a quiet, attentive regard for the other and the self that opens up alternative responsive possibilities. Concernful reticence is a restrained but attentive subversion. Irigaray describes the hopeful wonder of silence between difference that is resonant with my conception of concernful reticence. She writes:

[S]ilence is the condition for a possible respect for myself and for the other within our respective limits. It assumes that the already existing world, even in its philosophical or religious form, should not be considered complete, already revealed or made manifest. If I am to be quiet and listen, listen to you, without presupposition, without making hidden demands — on you or myself — the world must not be sealed already, it must sill be open, the future not determined by the past. $^{22}$

Here Irigaray articulates a liberative silence that is cognizant of the openness of the world. Silence allows for listening, and listening is a way of being-with others that does not presume upon the world or the word of another. The world is not closed and our interpretive possibilities are not restricted to hermeneutic constructs of the past. Whereas fundamentalist hermeneutics assume knowledge of the other and use external differences to categorize and objectify based on incomplete understandings of the world within a one-sided language, an invitataional feminist theological hermeneutic of concernful reticence makes no such demands. Instead, a person of concernful reticence quietly listens and waits for the appropriate and most effective moment to speak and act, realizing the open, incomplete possibilities of both world and language. If words 
must be spoken and if action must be taken, the concernfully reticent one chooses the parameters of her message and the location of her action. She is attuned to herself and her community.

Return with me for a moment to Esther's narrative. Esther is the character in the story whose concernful reticence brings salvation to her people and importantly she does not limit her own interpretive possibilities by external qualities such as sexuality, position, or ethnicity. Esther transcends the cultural constraints that had been imposed on her by virtue of her ethnicity as a Jew; her sexuality as a woman; her royal position as the queen; the law as a Persian citizen under the rule of Artaxerxes; and, the history of her people, both Jewish and Persian. Throughout the story Esther, with strength and quietude, moves from orphan to savior. First, Esther listens. She listens to Mordecai and wisely chooses to conceal her Jewish heritage. She listens to Hegai, the king's eunuch in charge of the harem and finds favor with "everyone who saw her." She again listens and heeds Mordecai's instructions concerning Haman's plot of annihilation. Finally, when she goes before the king on behalf of the Jewish people, she simply invites Artaxerxes and Haman to dinner and over the course of two evenings she waits and listens before making her request. Though complicit with the demands of the king, Esther was not constrained by the rule of Persian law, which seemed to imprison everyone else, including the king. This unusual freedom was possible because Esther was not merely a participant in the binding language of another, but was, in fact, creating a language of liberation that began with a concernful regard for the others in her social sphere. Esther's concernful reticence invited alternative ways of being-with others that countered the Enframing fundamentalisms of that time.

\section{Quiet Courage}

In addition to concernful reticence, a feminist theological hermeneutic teaches us to respond with courage amid the limited interpretive capacities of fundamentalisms that inform popular perception. Having been Enframed, the members of the social sphere frequently represent a forceful and oppressive collective such that liberation is only 
possible at great personal risk. Courage, then, is the necessary interpretive construct wherein we come to understand the fundamentalisms that distort difference within the community and choose to act with liberative, revolutionary intent. Whereas the action affirmed by fundamentalist hermeneutics is meant to manage and control others of difference, courageous care is liberating. In a similar description concerning the necessity of courage for speaking and acting in the social sphere Hannah Arendt writes:

The connotation of courage, which we now feel to be an indispensible quality of the hero, is in fact already present in a willingness to act and speak at all, to insert one's self into the world and begin a story of one's own. And this courage is not necessarily or even primarily related to a willingness to suffer the consequences; courage and even boldness are already present in leaving one's private hiding place and showing who one is, in disclosing and exposing one's self. ${ }^{23}$

In significant ways Arendt's call to courage resonates with Heidegger's leaping ahead. Courage is both present and necessary if we are to understand who we are and what we might be. And, this understanding is extraordinarily relational. As I make my way through the fundamentalisms that hinder my interpretation of difference I must leave things behind. My leaving is a courageous, disclosive, and liberative act. It is courage similar to what Rosemary Radford Ruether calls a "redemptive humanity that goes ahead of us, [and] call[s] us to yet incompleted dimensions of human liberation." 24 Ruether's description points to the courageous understanding that this world and our varied interpretative possibilities are not complete. At the threshold of the incomplete we arrive at the "brink of possibility." Here, in stark contrast to the standing reserve, we catch sight of liberating opportunities for the rich diversity of the social sphere. In another passage Ruether describes this not-yet world as a "new planetary humanity [that] goes hand in hand with the revolt of every oppressed group, in demands for national, class, racial, and sexual integrity and identity. ${ }^{, 25}$ Courage is the invitational 
care for the mutual liberation and understanding of those within the social sphere. It is the unending task of calling into question the fundamentalist constraints that inhibit our being-with others. Courageous, liberative work does not end once relief or aid has arrived. Rather, it is a continual and communal process. It is similar to the theological metaphor of a flourishing garden offered by Grace Jantzen, who writes: "The model of flourishing is one which assumes the interconnectedness of people, and indeed of the ecosystem: flourishing is impossible by oneself alone.[...] [F]lourishing is not once-forall, but is growth and process, never static." 26 Different from fundamentalist hermeneutics wherein others are stockpiled into categories of similitude and reserved for later use, courageous action is an ongoing, dynamic process of care with and for the community. Courage is the continual work of tilling the garden of the community for the hidden weeds of fundamentalism so that difference, rather than being generalized and objectified, might flourish.

Courage is demonstrated by a number of characters in Esther's narrative. Certainly Esther exhibits courage as she goes to the king on behalf of the Jewish people and calls Haman to account for his wickedness. And, Mordecai is also courageous in his strong appeal to Esther for her own understanding and the fate of the Jews. However, Vashti, the deposed queen, offers a rare picture of courage in the social sphere because in many ways she is the herald of the possibility of the salvation of the Jews that would come with Esther. While at first glance it might seem odd to name Vashti's actions as courageous, given that she simply said "No," Vashti's courage is evident in her simple refusal to be Artaxerxes' object. She refuses the King, risking much, and courageously accepts the opportunity to attend to her sexuality with care, thus inviting other women in the kingdom to understand alternative possibilities of being-with. Additionally, despite Vashti's defiance being made a negative lesson for all women of the kingdom, her initial act of refusal was a private matter that extended from her understanding of herself as a woman and was then carried out positively to the rest of the women by virtue of her position as queen. She interprets Artaxerxes' request as a vile demand on her sexuality and moves beyond her role as queen for her own sake. Her courage offers 
an opening for women in her kingdom to see other possibilities for their own gendered relationships.

\section{Mordecai: Fundamentalism, Courage, and Commonplace Practices of Care}

In these final moments I turn to Mordecai because, different from the other characters in the story, Mordecai reminds us that fundamentalism is a part, but not the whole, of who we are. Mordecai is remarkably human. In one instance he rejects Haman's dictum and acts upon an age-old culturally accepted discrimination on the part of the Jews against the Amalekites. But, in the next instance he is found preventing the assassination of the king, caring for his orphaned niece, and working to protect his people. Many times in the text Mordecai speaks loving words of sound wisdom to Esther-words that, like Jesus' to the lawyer, 'leap ahead' for Esther and invite her to see herself and her own possibilities of being. In these moments Mordecai is courageous and concernfully reticent.

Perhaps it seems out of place to include such a description of Mordecai. However, Mordecai's fundamentalisms are not quite as harsh as Haman's. And, his courageous and concernful reticence seems to pale in comparison with the liberative work of Esther. While the other characters in the narrative provide clear lines of demarcation between fundamentalist and alternative hermeneutic tendencies, Mordecai blurs these boundaries and asks us to admit to the everyday fundamentalisms so prevalent in our own ways of being-with others of difference.

I have described fundamentalisms as interpretive distortions of difference in which we have grown accustomed to poorly caring for others. Additionally, fundamentalisms skew our responses to difference on a number of relational levels including intimate relations and relations with unknown others within the social sphere. Thus far we have encountered fundamentalisms by examining, in many cases, the most extreme possibilities of both interpretation and practice. However, these extremes are only one side of pervasive fundamentalist hermeneutics. Fundamentalisms filter interpretation on a continuum of care. Importantly, how we find ourselves in the world 
with others and how we then care for difference is highly contextual, and wonderfully dynamic. The great hope of the hermeneutic structure of being-in-the-world is that our interpretive and responsive possibilities are many. We need not be Enframed by a fundamentalist interpretation of difference. Objectification and alienation are not the only possible outcomes of life together in community. Mordecai's hope is the realization that we are here ever in relation with others of difference who invite us to alternative hermeneutic possibilities. Mordecai teaches us that we need not relate so poorly the next time around.

The intent of this project has been clear from the start: to uncover the alwayspresent fundamentalisms that pervade our being-with and to consider alternative hermeneutic possibilities for sharing the world with others of difference. And like the questioning lawyer, the kinsman who failed to redeem, and Mordecai, we too have been restricted by fundamentalisms in which we poorly respond to others; and we too must struggle ever so diligently to see other interpretive possibilities that are available to us in the coming and presence of the other. 
${ }^{1}$ Hannah Arendt, The Human Condition (Chicago, IL: University of Chicago Press, 1958), 39.

${ }^{2}$ Alain Badiou, Saint Paul: The Foundation of Universalism translated by Ray Brassier (Stanford, CA: Stanford University Press, 2003), 13.

${ }^{3}$ Badiou, Saint Paul, 13.

${ }^{4}$ Mary McClintock Fulkerson and Sheila Briggs, eds. The Oxford Handbook of Feminist Theology (NY: Oxford University Press, 2012), 16.

${ }^{5}$ Esther 2:12

${ }^{6}$ Heidegger, The Question Concerning Technology 12.

${ }^{7}$ Heidegger, The Question Concerning Technology, 17 and 26.

${ }^{8}$ Elizabeth V. Spelman, Inessential Woman: Problems of Exclusion in Feminist Thought (Boston, MA: Beacon Press, 1988), 159.

${ }^{9}$ Suzanne Venker, The War on Men (Washington, DC: WND Books, 2013)

${ }^{10}$ Venker, "War on Men” in http://www.foxnews.com/opinion/2012/11/24/war-on-men

${ }^{11}$ The Flipside of Feminism: What Conservative Women Know-and Men Can't Say, How to Choose a Husband and Make Peace with Marriage, and 7 Myths of Working Mothers: Why Children and (Most) Careers Don't Mix

${ }^{12}$ Carey A. Moore, The Anchor Bible Daniel, Esther, and Jeremiah The Additions. (NY: Doubleday \& Company, 1977), 183.

${ }^{13}$ Irigaray, Way of Love, 6

${ }^{14}$ Heidegger, The Question Concerning Technology, 26-27.

${ }^{15}$ Irigaray, Between East and West, 93-94.

${ }^{16}$ Heidegger, The Question Concerning Technology, 26.

${ }^{17}$ Irigaray, I love to you: Sketch of a Possible Felicity in History, 10.

${ }^{18}$ Irigaray, I love to you: Sketch of a Possible Felicity in History, 10.

${ }^{19}$ It should be noted that my use of concern is a departure from Heidegger's notion of the same term. For Heidegger, concern is the interest or care directed at the objects or things in the world that are ready to hand (See Being and Time p. 157). My use of the term is more akin to 
Heidegger's notion of solicitude or care-with others. However, Heidegger's solicitude seems to advocate a certain absence of difference.

${ }^{20}$ Heidegger, Being and Time, 158-159

${ }^{21}$ Grace Jantzen, Becoming Divine: Towards a Feminist Philosophy of Religion (IN: Indiana University Press, 1999), 73.

${ }^{22}$ Irigaray, I love to you: Sketch of a Possible Felicity in History, 117 and 122.

${ }^{23}$ Arendt, The Human Condition, 186.

${ }^{24}$ Rosemary Radford Ruether, Sexism and God-Talk: Toward a Feminist Theology (MA: Beacon Press, 1993), 138.

${ }^{25}$ Rosemary Radford Ruether, New Woman, New Earth: Sexist Ideologies and Human Liberation (MA: Beacon Press, 1995), 189.

${ }^{26}$ Jantzen, Becoming Divine:Towards a Feminist Philosophy of Religion, 165. 


\section{Chapter 5: Invitation and Community}

\section{Overview}

If difference is the site of distorted perception and poor practices of care, we must consider how it is that we might share the world and build communities of difference together. Additionally, we must address the possibility of, or the ways we are enabled to recognize, the hidden presence of fundamentalisms within our interpretive landscapes as well as the possibility of other ways of being-with and caring for difference. In previous chapters I considered fundamentalism and alternative hermeneutics within various relational contexts, asking the questions: what is fundamentalism, what does it look like, and how might we see others differently? This chapter is a departure from the descriptive concerns of fundamentalism and therefore asks different questions.

The first question I consider has to do with the limited nature of our understanding. Given the concealed nature of the fundamentalist hermeneutic, how might we recognize our own incomplete interpretive constructs; and how are alternative hermeneutics thus disclosed? In order to examine this question I turn to the philosophical work of Hans-Georg Gadamer and Ramsey Eric Ramsey to suggest that fundamentalism is a matter of returning to our senses and finding distance and relief from the tyranny of hermeneutic dullness. Building a case for the return to our senses by humility and vigilant questioning I then consider the trouble with differences and the reality of irreconcilable difference, asking, how can communities be built and shared when differences are not only divisive but necessarily incompatible? This question leads me to the work of Alain Badiou wherein I find the real possibility of a hermeneutic of invitation which calls us back to ourselves and the other and is expressed in a particular practice of hospitality with and for difference.

The hermeneutic of invitation as well as the fundamentalist problem of dulled senses is further examined in the narrative account of the meeting between the Apostle Paul and Lydia. In their encounter we witness an invitational way of being-with others that enables and builds communities of difference. Paul does not limit his message to a 
particular person or group of people but speaks to all who have ears to hear. And Lydia is found ready to listen and engage in conversation with Paul. Each is willing to be invited by the other. Paul's truth is universal in its proclamation and demonstrates a practice of hospitality with difference whose invitation is uttered with others - in community. What we will see in the brief meeting of Paul and Lydia is a way of being with others that begins with the careful preparation of the self; a preparation that accepts the coming of the other and intentionally responds to difference with respect and in dialogue. Paul and Lydia embody a graceful hospitality that works outward from the self to the neighbor, the stranger, the sister, and the community.

\section{Why Paul?}

Before we examine the encounter of Paul and Lydia we must first consider Paul. Paul is a radical, even divisive figure. As it has been recorded in the majority of the books and letters of the New Testament, Paul's life and ministry could be characterized by extreme declarations and unrelenting faithfulness. His words of exhortation to the early church reveal a harsh affection that has been called sexist, exclusionary, and unforgiving. The case for Paul's fundamentalist proclivities is not difficult to argue. And yet, Paul was a man whose singular purpose was to care for others of difference by proclaiming the resurrected Jesus, and to maintain relationships and carry on dialogue with strangers speaking 'truth in love' in order to rescue them from the fundamentalism by which he had also been entrapped. ${ }^{1}$ Paul's method of practicing ministry is similar to Heidegger's notion of leaping ahead with others for the sake of their own freedom. Significantly, the message he proclaims is meant to liberate both Jews and Gentiles from their varied and limiting practices of formulaic religion and unreflective adherence to reason.

Paul is first introduced in the New Testament book of Acts as Saul, a young zealous Pharisee intent upon destroying followers of 'The Way,' which was the name given to the early Christian church. ${ }^{2}$ Saul was educated, devoutly religious, and wholly dedicated to his Jewish faith and heritage. He would not, could not tolerate the 
blasphemy being preached by the disciples of Jesus of Nazareth. After witnessing the martyring of Stephen, a bold truth-speaking church leader, Saul goes on a synagogueapproved rampage, ravaging the church, and entering house after house, dragging off men and women, committing them to prison. ${ }^{3}$ As he was 'still breathing threats and murder against the church ${ }^{4}$ Saul finds himself traveling to Damascus in order to ravage the church community there. While on the road a flash of light knocks Saul off his horse and as he lies there, blinded from the light of heaven, he hears the voice of Jesus of Nazareth asking, "Saul, Saul, why are you persecuting me?"5 Saul is then told by Jesus to go into the city of Damascus to wait for word and direction. Saul awakens physically blinded from this dreamlike trance and is led by his bewildered travel companions into the city where for three days he does not eat or drink and is in utter physical darkness. On the third day a follower of Jesus, Ananias, is told in a vision to go and release Saul from his blindness and to relay a message from God to him.

Saul recovers his sight, believes in the resurrected Jesus, and dedicates his life to the declaration of the message he so radically received on the road to Damascus. After his conversion Saul is known only as Paul. His life of murderous rage is over. He has been transformed, his name is changed, and he turns in the direction of difference- the Gentiles - for the sake of the truth by which he had been claimed. Paul spends the rest of his life proclaiming Jesus by engaging in purposeful dialogue with people of difference.

From town to town his practice of ministry was fairly consistent. Shortly after arriving in a new town he would seek out the public places of worship and after he had observed the people he would preach or question those who were there. He was not picky about his audience and was often found speaking to people who were radically different from him. In each city Paul chose to 'become all things to all people, that by all means,' some might be saved. ${ }^{6}$ Though this claim might sound as if Paul were some sort of chameleon who lacked any sense of self, Paul's way of 'becoming all things' was actually informed and enacted by virtue of his well-cultivated understanding of himself. The paradox of self-actualization together with communion with others of 
difference is precisely the reason why Paul is a truly remarkable character, specifically as his relationships and responses concern the fundamentalist hermeneutic we are attempting to elucidate. In the opening chapter of his book Saint Paul: The Foundation of Universalism, Alain Badiou asks the important question, "Why Saint Paul?" We might very well ask the same. Badiou's answer, or rather justification, for turning to the extreme and controversial figure of Paul is helpful:

Why Saint Paul? Why solicit this 'apostle' who is all the more suspect for having, it seems, proclaimed himself such and whose name is frequently tied to Christianity's least open, most institutional aspects: the Church, moral discipline, social conservatism, suspiciousness toward Jews? [...] Let us say that, for Paul, it is a matter of investigating which law is capable of structuring a subject devoid of all identity and suspended to an event whose only 'proof' lies precisely in its having been declared by a subject. What is essential for us is that this paradoxical connection between a subject without identity and a law without support provides the foundation for the possibility of a universal teaching within history itself. Paul's unprecedented gesture consists in subtracting truth from the communitarian grasp, be it that of a people, a city, an empire, a territory, or a social class. ${ }^{7}$

What we witness in Paul's doctrine and practice offers a robust understanding of a hermeneutic of invitation that cuts through external particularities, offering relief from the fundamentalist fore-structure that limits our ways of being-with others in the world. Paul is a historical figure of extremes. He, like us, was humanly constrained by the fundamentalism so characteristic of being-in-the-world. Yet, his relationships taught him to love, to welcome and to extend and receive grace-filled hospitality with others. To be sure, Paul is a figure of contradiction and controversy; and Paul is a man whose understanding and practice of truth transcend external markers of difference. If we let 
him, Paul can teach us a thing or two not only about the destructive consequences of fundamentalism but also about the hopeful possibility of sharing community with others; this is instruction that contributes significantly to interpreting and responding to difference through a feminist theological hermeneutic of invitation.

\section{Narrative: Lydia and Paul}

Though Paul's practice of ministry in Philippi is consistent with his other missionary stops, his relationship with Lydia is a striking departure form the establishment of earlier communities of faith by the apostles of the early church. For the sake of context, this departure is worth considering. In the first place Lydia was a woman. While women had been a prominent part of the church — beginning with the women who cared for and traveled as friends of Jesus, Lydia is the first in Philippi to believe. The other recorded "first converts" in the churches started by Paul and Peter were men. And it is significant to mention, as Arthur Sutherland has rightly noted, that Paul went to Philippi after having had a dream in which a man appeared from Macedonia calling for Paul to come and preach the gospel. ${ }^{8}$ Citing this vision and the peculiar situation of finding Lydia, Sutherland suggests that Paul comes to Philippi expecting to find a man. After having been in the city three days, and failing to find not only a man but also a synagogue in which to preach, he is greeted rather unexpectedly by Lydia, a woman who was not

even Philippian. ${ }^{9}$ Lydia's gender must have taken Paul by surprise, but Paul wastes no time in proclaiming the gospel. Significantly, her gender is not a barrier to possibilities of belief, for Lydia or Paul.

So setting sail from Troas, we made a direct voyage to Samothrace, and the following day to Neapolis, and from there to Philippi, which is a leading city of the district of Macedonia and a Roman colony. We remained in this city some days. And on the Sabbath day we went outside the gate to the riverside, where we supposed there was a place of 
prayer, and we sat down and spoke to the women who had come together. One who heard us was a woman named Lydia, from the city of Thyatira, a seller of purple goods, who was a worshiper of God. The Lord opened her heart to pay attention to what was said by Paul. And after she was baptized, and her household as well, she urged us, saying, "If you have judged me to be faithful to the Lord, come to my house and stay." And she prevailed upon us. (Acts 16:11-15)

The account of their meeting is short. Paul, being led in a vision, goes to Philippi, finds no synagogue and after a few days comes to the banks of a river where Lydia and her friends are praying. Paul preaches. Lydia believes and is baptized. Lydia then, on the basis of her newfound faith and from an understanding of equality with Paul, insists upon hosting Paul as a guest in her home. Paul refuses. Lydia persists, and Paul stays in her home. Though brief, this narrative offers a compelling rendering of the fundamentalisms that limit our interpretations of difference as well as alternative possibilities of being-with with others.

\section{Returning to Our Senses: Fundamentalisms and Being Hard of Hearing}

We have come to understand that the fundamentalist hermeneutic frequently affirms and promotes impoverished practices of care within the private and social spaces of our worlds. Fundamentalism filters and distorts our interpretive and responsive possibilities for others by exaggerating and diminishing difference. In previous chapters we undertook the task of describing common fundamentalist inclinations and their associated forms of care. From this foundational analysis we now turn and consider different questions related to the fundamentalist phenomenon. Rather than examining what fundamentalism looks like and how the fundamentalist hermeneutic is exhibited in relation with others of difference, we now ask why? and what now? Following Heidegger's explication of the hermeneutic structure of existence, Hans-Georg Gadamer asks, "How can we break the spell of our own fore-meanings?" 
that our interpretive capacities are so limited by fundamentalist distortions of difference? Why are we so willfully ignorant of the fundamentalisms that wreak havoc in our relationships and in our worlds? In the gospel of Matthew Jesus of Nazareth boldly calls religious pretenders to their senses by proclaiming, "He who has ears to hear, let him hear." ${ }^{11}$ Hearing, seeing, and being-with: these are the corporeal orientations of one whose senses are attuned to herself and the others in the world. However, often it is the case that fundamentalism has dulled our senses such that though we have bodies, we do not inhabit them in sense-able ways. I have chosen an unconventional spelling of a common term to indicate the hopeful reality of our ability to recover our senses. Though our senses are clouded and we are, or have become, hard of hearing, we are yet sense-able.

Fundamentalism is a trans-historical hermeneutic possibility of being-with others in the world. That is to say: though fundamentalism is historically and socially contextualized in (mis)perception and practice, it is a hermeneutic of distortion that has been granted to us in various ways throughout all periods of human history. Moreover, as with all interpretive constructs, the fundamentalist hermeneutic is not apparent to its inheritors. Gadamer speaks of the concealed nature of heremeneutic fore-structures granted to us by tradition, writing, "It is the tyranny of hidden prejudices that makes us deaf to what speaks to us in tradition." 12 Prejudice is the term Gadamer uses to describe the concealed patterns of thought that filter and inform our understanding of things, and tyranny is the overwhelming control such prejudices have over us. Fundamentalism, like a tyrant, has long informed our ways of being-with such that we have become deaf to other possibilities of sharing and being-in-the-world with others. Importantly, other ways of being-with, though not easily perceived, have been available all along. Recognizing and interpreting within alternative hermeneutics is thus a matter of hearing things differently, or hearing things at all. Fundamentalism stifles our hearing and constrains our understanding such that we no longer remember that there might be other ways and other words. 
Returning to our senses is a hard and constant struggle. It is, as Gadamer suggests, a matter of recognizing and questioning the "imperceptible habits of thought" that frame interpretation. ${ }^{13}$ Importantly, the hermeneutic task of calling to mind and questioning the validity of long-held interpretive constructs is always incomplete and specifically hindered by a fundamentalist hermeneutic. Yet, the incompleteness of our understanding and the necessity of vigilant questioning point us toward the hopeful possibility of interpreting and responding otherwise - with all our senses. Seeing, hearing, and responding other than through our fundamentalist inclinations depends upon the incompleteness of our understanding and, as Ramsey Eric Ramsey has described, upon the "surplus of meaning [which] allows for the clarification of the possibilities that come from our past and open out onto our future. ${ }^{, 14}$ Relief from the divisive pressures of our imperceptible fundamentalist habits of thought is granted as we learn to listen and respond to the multiple meanings available to us in any and every encounter with difference. Responsive listening is a matter of readiness and grace: readiness to receive the unexpected other with attentive regard for the surplus of meanings in their coming, and grace to accept the reality that understanding togetherness is always a work in progress. In similar terms Ramsey develops communicative praxis as an ethics of relief wherein diligence and humility allow alternative possibilities of meaning to show themselves. ${ }^{15}$ And Gadamer has articulated the hermeneutic task as a matter of openness, questioning, and readiness, writing:

The hermeneutical task becomes of itself a questioning of things and is always in part so defined. [...] A person trying to understand something will not resign himself from the start to relying on his own accidental fore-meanings, ignoring as consistently and stubbornly as possible the actual meaning of the text until the latter becomes so persistently audible that it breaks through what the interpreter imagines it to be. Rather, a person trying to understand a text is prepared for it to tell him something. 
That is why a hermeneutically trained consciousness must be, from the start, sensitive to the text's alterity. ${ }^{16}$

Understanding is a matter of readiness and willingness to wrestle with interpretive constructs that have hindered our responsive possibilities. It is a matter of freeing our imagination to consider other ways of being-with. It is an ongoing process that demands attention to the ways and words we have long taken for granted. It is the willingness to listen and respond to the varied utterances of the unexpected and multiple possibilities of meaning made available in the coming of another. Understanding is a practice in grace as we find relief from the binding constraints of fundamentalisms that inhibit our forms of care and distort our perception of difference. Fundamentalisms constrain our responsive inclinations by dulling our senses thereby convincing us that our long-held ways of being-with need not be questioned. Fundamentalism is a hermeneutic structural possibility of our every encounter with difference. Significantly, fundamentalism clouds our judgment and covers over our interpretive inclinations. However, returning to our senses, though difficult, is not impossible.

\section{Paul, Lydia and the Trouble with Hearing Difference}

By returning to the apostle Paul we find a demonstration of the sense-able limitations of fundamentalisms. Though Paul simply refuses Lydia's kindness, his refusal is indicative of a life-long struggle with fundamentalism that seems unable to listen and accept care from the words and arms of people of difference. To be clear, Paul was a willing apostle to the Gentiles - that much is certain. Unlike Paul's contemporary Peter, who was troubled by the inclusion of Gentiles in the burgeoning community of believers, Paul took little convincing of his mission and was happy to carry the message of resurrection to the non-Jewish world. ${ }^{17}$ However, Paul's fundamentalist hermeneutic does not appear in his faithful proclamation of the gospel to people of difference, but rather when he has to be on the other side of the conversation; when he must listen. Paul has little difficulty finding people for a conversation, and he has no trouble speaking to them about the 
truth that changed his life, but he has difficulty responding when they begin to speak. In this way, Paul is much like the description Irigaray offers of people who breathe and speak in an "inverse proportion" where words are suffocating and stifling. ${ }^{18}$ Paul is all too happy to fill the space between with his words, but as he speaks he leaves little room for the breath, space, and words of another. His unwillingness to be cared for by Lydia may have been partly due to her gender difference, but that she prevails also suggests that Paul's trouble with her request had more to do with his difficulty hearing her. The text states that Lydia 'prevailed upon' him, urging him strongly, insisting that he stay as a guest in her home. Paul had to be convinced. In this way Paul was ready to encounter others on his own terms but not as well prepared to hearken to the voice of another. Even his conversion is a demonstration of the need for loud cries to awaken him from the slumber of thought and practice. Paul was a contemporary of Jesus and he could not hear the message while Jesus was alive. Paul was a persecutor of the early church and was unable to listen to the words spoken to him about the resurrected Jesus. Paul was converted by blinding light and the thundering voice of heaven, which knocked him off his horse. Certainly, Paul's trouble with listening is worsened by his packed speaking schedule and his international preaching agenda. Indeed, if we are always speaking, listening becomes an arduous task. However, I would argue that Paul is willing to listen, but he is hard of hearing.

Paul was ready to speak truth to Lydia but his responses were limited by the fundamentalist fore-structure of his thought. In other words, he could see and respond to Lydia because she was there, but her home, the place she had made for sharing and the residence to which Paul was invited, was just beyond sight. He could speak to her and his message was life-giving, but he could not hear her or speak with her until she prevailed upon him. What we witness in Paul's first response of refusal is yet another demonstration of Heidegger's understanding of "leaping ahead" for the sake of the other. Paul arrives in Philippi looking to speak truth, to leap ahead for all who would hear- to utter words of saving grace. That is Paul's singular desire. When he finds Lydia he does just that: he is a messenger and she hears. But what Lydia does for Paul 
is truly remarkable; she leaps ahead for him. Lydia understands the power of the message and calls Paul to practice that truth lovingly, in the moment, right then: she asks him to respond to her, to hear her on the basis of the truth he proclaims. Paul comes to his senses. He accepts her invitation. He chooses a way that diverges from the fundamentalist inclinations that have long had a hold upon him. And in her invitation and his choice to accept her kindness we see hopeful alternative hermeneutic possibilities of being-with. Contrary to a fundamentalist hermeneutic wherein others are spoken over, unheard, and denied access, Lydia and Paul lead us to the possibility of alternative interpretive frameworks. Their encounter demonstrates other ways of beingwith; ways that listen and respond to others in openness, readiness, and humility. Contrary to the fundamentalisms that clouded their perception, Lydia and Paul urge us toward a sense-able hermeneutic of invitation, manifest in what I have called gracefilled hospitality.

\section{A Hermeneutic of Invitation}

Having disclosed the sense-dulling nature of fundamentalist hermeneutics, we arrive at an important question for being-with others of difference. If fundamentalisms as well as alternative interpretive possibilities are hidden, how are we to become aware enough to even begin the questioning necessary to choose otherwise? How are we to see and hear the absent and imperceptible? While previous chapters have primarily focused on alternative hermeneutics for interpreting and responding to others, this section considers the possibility of a feminist theological hermeneutic that begins by attending to the fundamentalist distortions of difference within the self. Indeed, in order to care well for others of difference, we must first, as Ramsey has articulated, be afforded "relief" to understand our own fundamentalist inclinations. Thus, we turn to a feminist theological hermeneutic of invitation.

The opening words of a familiar passage of the Old Testament find the Jewish prophet Isaiah crying aloud, inviting all who would hear. He cries: 
Come everyone who thirsts, come to the waters; and he who has no money, come, buy and eat! Come, buy wine and milk without money and without price. Why do you spend your money for that which is not bread, and your labor for that which does not satisfy? Listen diligently to me, and eat what is good, and delight yourselves in rich food. Incline your ear, and come to me; hear, that your soul may live. ${ }^{19}$

Isaiah's words are meant to convey an open invitation, full of emotion. It is compelling, and it is a call to return and taste, see, and hear. Importantly, it is an invitation to question the vanity of that which does not satisfy. Come. Listen. Hear. Be satisfied. Here, in Isaiah's invitation, we catch sight of the vast possibilities of a hermeneutic that begins with an invitation. Gadamer points to a similar hermeneutic possibility, writing: "[W]hat leads to understanding must be something that has already asserted itself in its own separate validity. Understanding begins [...] when something addresses us. [...] The essence of the question is to open up possibilities and keep them open." ${ }^{, 20}$ The question, the hermeneutic undertaking, is by its very nature an invitation. As such, invitations provide the necessary distance to hear the buried sounds of the hermeneutic possibilities harbored beneath the fundamentalisms so prevalent in our ways of beingwith difference.

A hermeneutic of invitation works outward from the self and into the interpretive vantage points of our encounters with others. Invitation calls into question hidden fundamentalisms and unearths the surplus of meanings within varied relational contexts. Returning to our senses thus becomes a joint endeavor of continual invitation, question, and interpretation. Here we take hold of the hermeneutic possibility of invitation. Understanding and thereby interpretation is always a joint endeavor. In earlier chapters Heidegger helped to disclose that we are always with. The withness of the world is the ground in which invitation is possible. We are invited to the hermeneutic task of the sense-able perception of other ways of being-in-the-world. Furthermore, if we allow it, the difference that is so divisive within a fundamentalist 
hermeneutic can be the invitational catalyst that serves to wrest us from ourselves and the imperceptible habits of thought by which we have long been constrained. Difference can awaken us from the slumber of fundamentalism and invites us to discover alternative ways of being together. Said differently, the ability to perceive beyond our surface-level interpretive constructs depends upon difference and is made known through invitation. Irigaray offers a telling description of welcome that creates openings for mutual becoming and suggests that sharing worlds is a matter of listening well and looking for alternative ways to be with one another for our mutual becoming. ${ }^{21}$ Here we see that listening, or a sense-able regard for the invitation to understand multiple interpretive possibilities, makes way for the creation of new worlds and communities of difference.

\section{Lydia's Invitation}

In the brief encounter between Paul and Lydia we witness a picture of what a hermeneutic of invitation might look like between people of difference. Though Paul was often found preaching to large numbers of people, his preferred method of address was more akin to a personal monologue spoken to individuals rather than a sermon uttered to a crowd. Even his letters often concern specific people and particular circumstances. The conversion of Lydia is no different. He meets her, and her friends, one on one. He shares truth with her. But what is striking about Lydia is that she, upon hearing, turns Paul's prepared monologue into a dialogue meant to be shared. Paul speaks. Lydia listens and believes - and then she too speaks a word that requires a decision. She listens, she is open, and she invites. She does not speak until she has heard, and she is willing to listen to the words of a stranger. Her silence is her invitation. Here we see that invitation has to do with the recognition that what needs to be said has not yet been spoken. Silence is the first utterance of invitation because in silence each one relinquishes preconceived notions about the world and the other and creates a space of possibility for the arrival of the other. ${ }^{22}$ In the practice of silence we 
see a significant distinction between Lydia and Paul: Paul finds Lydia and speaks, while Lydia greets Paul with silent respect. She respects his coming and his spoken word. And she respects herself enough to leave open possibilities of encounter by listening and risking conversations with people of difference. Lydia's silence also indicates her desire to hear or listen to Paul. Lydia desires the words of Paul, and her desire is her invitation. Desire is a crucial part of Irigaray's call to share the world and is vitally connected with her notion of welcome. Speaking of desire as " $[t]$ he longing for the other [that] calls for a beyond of a world of one's own, ${ }^{23}$ Irigaray reveals a marked difference between Paul and Lydia. Paul desires to speak, he wants his words to care for Lydia. He wants her to believe. He wants her to listen, and Lydia does just that because she, unlike Paul, wants and is ready for the words he had not yet even spoken. Paul's words usher Lydia into an understanding of a world beyond herself and she longs to enter that world, recognizing and desiring that he too share her world. Her desire, her invitation, is a subtle celebration of their difference. Lydia accepts an invitation from Paul to consider herself and her ways of being-in-the world. She questions her own imperceptible habits of thought and in so doing understands alternative meaningful possibilities. Their conversation was the site of her belief that led her to new and hospitable possibilities of interpreting others of difference.

The concept of hospitality is richly theological, and many scholars have offered fitting definitions. Arthur Sutherland has proposed that “[i]n light of Jesus' life, death, resurrection, and return, Christian hospitality is the intentional, responsible and caring act of welcoming or visiting, in either public or private places, those who are strangers, enemies, or distressed, without regard for reciprocation. ${ }^{.24}$ Hospitality is the outward expression of the hermeneutic of invitation that transcends external markers of difference in order to care well for another. Importantly, as has been observed in each of the narratives thus explored, hospitality is the embodiment of a particularly dialogic practice of care that invites others of difference into conversation. Among the variety of hospitable ways of being-with others, I argue that Lydia's hospitality was graceful. The notion of grace adds important texture to an already beautiful concept. And, like 
hospitality, grace also is rich with theological possibility. Millard J. Erikson defines grace as abundant, compassionate, undeserved generosity. ${ }^{25}$ Grace is a way of beingwith others, where practices of care are not so easily constrained by the (mis)perceived external particularities. The graceful hospitality that I propose is best understood as the undeserved, intentional, and generous creation and cultivation of personal and private spaces in order to welcome, protect, share, and provide for another without reciprocation. Within such hospitality words are few, but they are powerful and seasoned with attentive sense-able regard for the other with whom the conversation and the community is shared.

\section{Communities of Grace-Filled Hospitality Through Difference: Paul \& Lydia}

Hospitality, then, is radically other than fundamentalist practices of care. Instead of turning away and protecting ourselves from difference, hospitality is the invitation to share life and worlds together; to expose ourselves to the difference of others; to share our fragility, our humanity with them. It is the embodiment of a hermeneutic of invitation wherein difference is not distorted, but rather given the space and grace to be. However, hospitality allows difference to be made a welcome part of our communities, both public and private. We have already discovered that fundamentalism(s) necessarily exclude(s) difference from communities where sameness is both imagined and determined to be of fundamental value. Here we arrive at the final question of this chapter. Namely, how is hospitality possible in the face of irreconcilable differences?

In previous chapters we understood that the fundamentalist hermeneutic distorts our perception and response to difference by exaggeration and diminishment. We also recognized that some differences are more weighty and perhaps even irreconcilable with other differences. Adam Philips examines the reality of competing and incompatible fundamentals and writes:

But we should not be assuming that what is most fundamental to uswhether we are aware of it or not - is necessarily conducive to harmony 
with ourselves or others. Indeed we may have to acknowledge, absurd as this might seem, that what is fundamental to us - or the defense of what is fundamental to us - can be the very thing that destroys us. That only what makes our lives worth living is worth dying for. ${ }^{26}$

We must admit the validity of Philips' claim. Though we may not be able to articulate the imperceptible habits of thought through which differences have come to matter to us, there are differences of fundamental concern without which we would cease to be ourselves and for which we would be compelled to fight. With this understanding in mind we return to hospitality in order to demonstrate that we need not reduce possibilities of community to empty descriptions of imagined utopia. Instead, hospitality is a way of being-with in community where differences are an invitational catalyst for sharing the world. Hospitality is a way of being-with unconstrained by the differences that would in most circumstances be divisive. Alain Badiou calls upon Paul's response to difference within the church communities he founded. He writes:

With regard to the world in which truth proceeds, universality must expose itself to all differences and show, through the ordeal of their division, that they are capable of welcoming the truth that traverses them. What matters, man or woman, Jew or Greek, slave or free man, is that differences carry the universal that happens to them like a grace. Inversely, only by recognizing in differences their capacity for carrying the universal that comes upon them can the universal itself verify its own reality: "If even lifeless instruments, such as the flute or the harp, do not give distinct notes, how will anyone know what is being played on the flute or the harp?" (I Cor. 14:7) Differences, like instrumental tones, provide us with the recognizable univocity that makes up the melody of the True. ${ }^{27}$ 
For Badiou, truth is matter of remaining faithful to the declaration of a world-altering event that has already turned things upside down. Truth is found in our attempt, however clumsy, to weave the event into the fabric of our world(s). Like Paul's conversion on the Damascus road which simultaneously shattered his previously held religious understanding and made way for a new utterance grounded in the message received in the event, truth is a universal happening, to which we must and always do respond. Suggesting that grace might be understood as "the idea that every existence can one day be seized by what happens to it and subsequently devote itself to that which is valid for all," ${ }^{28}$ Badiou proposes a distinctly communal understanding of difference. Truths cut across, traverse difference such that differences are the site of the declaration and proclamation of truth that has happened to all. Said differently, differences reveal alternative and life-giving ways of relating with others.

The hospitality I am articulating takes Badiou's sense of graced truth-event further. With regard to difference in community, hospitality is the worldly possibility of a dialogic hermeneutic of invitation where difference is welcomed in various ways. Badiou suggests that "[e]very truth is dependent upon something whose existence had been totally unapparent acceding to the flush of appearance." ${ }^{29}$ Furthermore, this appearance is incorporated in the world and carried out in bodily utterances or declarations which serve to "rais[e] up [the] inexistent" event. Difference is the unexpected and unapparent truth event to which we, in community, are given the opportunity to respond, declare, and be-with. The universal impetus of difference, which is an unexpected evental site of a truth Badiou calls love, is that which cuts through external particularities calling for response and declaration. Difference is grace and event while hospitality is the invitational way that differences come to matter for the mutual flourishing of all. Hospitality is the outward expression of a hermeneutic of invitation in which we gracefully respond to others of difference whose coming is always underway, but never as we might expect.

Lydia was the first convert in Philippi, and she was a woman whose differences far outweighed her similarities with the traveling apostle. But the apostle, though taken 
aback, was not concerned with her gender, her nationality, or her previous ways of worship: he was singularly focused and intensely devoted to the truth by which he had been claimed. His message transcended the barriers of external difference and her reception made way for an outpouring of that truth to be immediately declared. Their differences did not obstruct but rather enabled them to care for one another in particular ways. In a similar articulation of what she calls a "wholeness of vision," Sheila Collins rightly states that "[o]nly through an affirmation and celebration of our differences can we come to an understanding of the ties that bind the whole creation together. A holisitic ethic [in a pluralistic world] affirms singleness within community, diversity within unity, the validity of both and rather than either or. ${ }^{, 31}$ Collins' description of a holistic ethic is much like the invitational hospitality I propose. Instead of searching for similarities from which care could be glimpsed, communities can be reconstituted on the basis of the ever-present invitation of difference. Irigaray's notion of becoming might be employed here in terms of difference that makes way for the invitational reception of the other. She writes:

The meaning of "identity" is then modified insofar as it is no longer determined by the same understood as an equivalence between two terms - be they "thinking" and "Being." It is rather the difference between two terms - man and woman - that brings each one back to oneself thanks to the construction of a temporality in which relation to the same does not take root in a tautology but in a becoming. The same, from then on, is not appraised as similitude but as a fidelity to oneself compelled by the care of the human, particularly as care of the other. ${ }^{32}$

Irigaray cannot limit understanding and identity to banal versions of sameness, which, incidentally, is the trouble with founding communities where difference is merely tolerated. Rather, identity must be rooted in the particularities of difference that give rise to multiple possibilities of human becoming. The care Irigaray describes is similar 
to the invitational hospitality I am proposing. Attending to one another through difference is the hospitable way they become. Within this hospitality the way is made for community and the care of the other is enabled, not restricted, by the difference of each. In such a community, difference is of immense importance, not because it strikes a chord of dissonance, but because each is a melody of her own and is the catalyst for the hospitable expression of invitation with others in harmony together. Instead of a fundamentalist retreat from difference, a hermeneutic of invitation expressed in graceful hospitality is an inclination or attunement in the direction of the unexpected other. Thus, invitation allows us, like Lydia and Paul, to interpret and respond to each other with and through, not in spite of, difference. Notions of attunement bring us full circle to the necessary return to our senses allowed in an invitational hermeneutic that entails first attending to one's self and then to the others with whom the world is shared.

Lydia and Paul were able to respond to one another apart from their own expectations and within and through their differences. For them, the riverbed of encounter was a invitational opportunity for dialogue through difference. Rather than interpreting Paul as another representation of an already-defined world, Lydia accepts Paul's coming and his proclaimed differences as an event, full of invitational possibility. Instead of disregarding Lydia for being other than his expectations, Paul greets her as an equal. And Lydia too invites Paul to see things differently. She invites him to experience her world, to accept her provision, to join with her in her newfound belief. The riverside was a public place of meeting. At the riverside they were strangers. Her home was a private space of intimacy. In her home they were friends. What Lydia offers Paul is more than lodging. Her hospitality begins to construct a path between separate worlds. Their encounter and their invitational dialogue enacts a hospitality that facilitates a sense of community formed, not on account of a fundamentalist fetish of sameness, but for the sake of the difference between. 
${ }^{1}$ Ephesians 4:15.

${ }^{2}$ Acts 9:2.

${ }^{3}$ Acts 8:3.

${ }^{4}$ Acts 9:1.

${ }^{5}$ Acts 9:4.

${ }^{6}$ I Cor 6:11.

${ }^{7}$ Badiou, Saint Paul: Foundation of Universalism (CA: Stanford University Press, 2003), 4-5.

${ }^{8}$ Acts $16: 9$

${ }^{9}$ Arthur Sutherland, I Was a Stranger: A Christian Theology of Hospitality (Nashville, TN: Abingdon Press, 2006), 44

${ }^{10}$ Hans-Georg Gadamer, Truth and Method translated by Joel Weinsheimer and Donald G. Marshall (NY: Continuum, 2004), 270.

${ }^{11}$ Matthew 11:15

${ }^{12}$ Gadamer, Truth and Method, 272.

${ }^{13}$ Gadamer, Truth and Method, 269.

${ }^{14}$ Ramsey Eric Ramsey, The Long Path to Nearness: A Contribution to a Corporeal Philosophy of Communication and the Groundwork for an Ethics of Relief (Atlantic Highlands, NJ:

Humanities Press International, Inc., 1998), 104.

${ }^{15}$ Ramsey, The Long Path to Nearness, 109.

${ }^{16}$ Gadamer, Truth and Method, 271.

${ }^{17}$ Acts 10 .

${ }^{18}$ Irigaray, I love to you: Sketch of a Possible Felicity in History, translated by Alison Martin (NY: Routledge, 1996), 121.

${ }^{19}$ Isaiah 55:1-3a.

${ }^{20}$ Gadamer, Truth and Method, 298. 
${ }^{21}$ Luce Irigaray, Sharing the World (London: Continuum, 2008), 23. "There is not yet a sharing of Being, which presupposes opening oneself to becoming to which we agree to be attentive, to listen. [...] [To] a human becoming that calls into question what has already happened to humanity, and that allows and clears the way for new perspectives on Being, with new obligations and possibilities for human blossoming. [...] It is only at such a price that we can prepare a welcome for the other, whomever this other could be: a companion, a friend, a child, a foreigner. It is always a question of how to become capable of being with the other, and of making a new world, a third world, exist between us."

${ }^{22}$ Irigaray, Sharing the World, 17-18.

${ }^{23}$ Irigaray, Sharing the World, 71.

${ }^{24}$ Arthur Sutherland, I Was a Stranger: A Christian Theology of Hospitality (Nashville, TN: Abingdon Press, 2006), xiii.

${ }^{25}$ Millard J. Erikson, Christian Theology (Grand Rapids: MI, Baker Book House, 1985), 294295.

${ }^{26}$ Adam Phillips, "On What is Fundamental” in Salmagundi, vol. 162/163, Spring 2009, 81.

${ }^{27}$ Badiou, Saint Paul: The Foundation of Universalism, 106

${ }^{28}$ Badiou, Saint Paul: The Foundation of Universalism, 66.

${ }^{29}$ Badiou, Second Manifesto for Philosophy translated by Louise Burchill (Malden, MA: Polity Press, 2011), 83.

${ }^{30}$ Badiou, Second Manifesto, 87.

${ }^{31}$ Sheila D. Collins, A Different Heaven and Earth (PA: Judson Press, 1974) in cited by Pauli Murray in "Salvation and Liberation," sermon reprinted and edited by Bettye Collier-Thomas, Daughters of Thunder: Black Women Preachers and Their Sermons, 1850-1979 (San Francisco, CA: Josey Bass, 1998), 266.

${ }^{32}$ Irigaray, The Way of Love, 82-83. 


\section{Chapter 6: Fundamentalism: Final Words and Future Implications}

We have come to understand fundamentalism as a hermeneutic structural possibility for being-with others in the world. Within each of the chapters I uncovered common fundamentalisms that distort difference and affirm poor practices of care for others. The descriptions I have provided of fundamentalist inclinations between strangers, family, and in the social sphere are most assuredly not the only possibilities of fundamentalist being-with. However, the descriptions, extreme as they may be, offer insight into common fundamentalist tendencies prevalent in specific relational contexts. Significantly, interpretive constructs are by nature hidden; fundamentalisms work against this hiddenness by dulling our senses, making us comfortable with limited interpretative possibilities. But, and hopefully so, we are not as comfortable in our hermeneutic numbness as we might have thought.

The hermeneutic structure of existence necessitates an openness to multiple possibilities of meaning on a number of interpretive levels. As such, the interpretive constructs through which I have developed this broad understanding of fundamentalism are necessarily partial and limited. Gadamer, following Heidegger, describes the circular interplay between understanding and the forestructures that shape that understanding, writing:

Heidegger describes the circle in such a way that the understanding of the text remains permanently determined by the anticipatory movement of fore-understanding. The circle of whole and part is not dissolved in perfect understanding but, on the contrary, is most fully realized. [...] The anticipation of meaning that governs our understanding of a text is not an act of subjectivity, but proceeds from the commonality that binds us to tradition. But this commonality is constantly being formed in our relation to tradition. Tradition is not simply a permanent precondition; rather, we 
produce it ourselves inasmuch as we understand, participate in the evolution of tradition and hence further determine it in ourselves. Thus the circle of understanding is not a "methodological" circle, but describes an element of the ontological structure of understanding. ${ }^{1}$

The notion of a hermeneutic circle further illustrates the ongoing process of meaningmaking which is always constrained by partial understanding, and dependent on places of entry into the circle. Both understanding as well as the varied interpretive constructs through which we come to understanding are reciprocally related to one another. That is to say neither my elaboration of fundamentalisms, nor my descriptions of alternative hermeneutics are exhaustive. My understanding of the phenomenon is contextually situated at the juxtaposition of a particular philosophic heritage and the biblical text. However, this is not to suggest that fundamentalisms can only be understood by way of these entry points into the hermeneutic circle. With this in mind, the intent of this chapter is to address some further possibilities for the hermeneutics I have described.

\section{Possibilities for Interpersonal Communication Studies}

In the brief introduction to Vattimo's Belief, Luca D'Isanto describes hermeneutics as a philosophical project where truth is possible "precisely because it is aware of being

merely a provisional — therefore never definitive, never-ultimate — interpretation." ${ }^{2}$ This notion of the never ultimate process of hermeneutics as well as Heidegger's description of the with-ness of the world allow me to propose liberating communicative possibilities for sharing worlds with difference. The explication of the fundamentalist and feminist theological hermeneutics must not end with a simple description. Instead we must find ways to think and be together within alternative hermeneutic constructs. In other words, what can be done with the hermeneutics I have uncovered?

First, hermeneutics are expressed in communication. That is to say, the outward manifestation of our interpretive constructs are evidenced in our communicative practices of care and ways of being-with others. In each of the previous chapters we 
encountered relationally specific fundamentalisms as well as alternative hermeneutics for being-with in particular ways. Though communication scholars have certainly described the relational nature of communication, the hermeneutic possibilities that I have uncovered push interpersonal communication to a deeper level of responsibility and practice. I propose that communication is a hermeneutic event where being-with is enacted in various ways. It is the joint endeavor of unearthing long concealed hermeneutic inclinations. The hermeneutic of invitation I have described is expressed in communication and marked by vigilant self-reflection that elucidates greater interpretive and responsive possibilities for being-with others in the world. I do not articulate specific steps to gain or develop appreciation and respect for the self and people of difference. Certainly such actions are a helpful way to think about being-with others in the world. However these surface level actions rarely, if ever, result in the realization that caring well for others of difference is an ongoing process of understanding. Steps for communicative practices between diverse people are a handy way to treat the symptoms of fundamentalist relational constraints. But importantly, the hermeneutic of invitation that I have uncovered is a continuous process of selfreflection that "gets to the heart" of our varied fundamentalisms and in so doing reveals particular ways of attending to difference within specific relational contexts. ${ }^{3}$ In the forward to the second edition of Truth and Method Gadamer describes the purpose of his project, writing: "My concern was and is philosophic: not what we do or what we ought to do, but what happens to us over and above our wanting and doing."4 Gadamer's intention reflects both the presence of hidden interpretive constructs as well as the incomplete nature of any communicative encounter. This understanding of the things that happen to us over and above our desires is a foundational construct of dialogic communication. For example, John Stewart describes the "continuously emergent" quality of communication and writes:

Communicating individuals might usefully visualize themselves as moving together along [a] helical line, integrating individual and shared 
expectations and actions with new interpretations that result in outcomes being more than just 'the same thing over and over'; in other words, understanding that outcomes are continuously emergent. [...] This means, $[\ldots]$ that every communicative contribution that any person makes can be understood to be responsive to what preceded and contextualizes it and that communicative outcomes [...] are continuously emergent — always opening out into what happens next. ${ }^{5}$

For Stewart, the ethical component of communicative encounters is grounded in the ongoing, always partial character of understanding in relation with others. And, the outcomes of our varied communicative "choices" are not limited to our intentions. Said differently, communication is contingent upon the hermeneutic forestructures of our understanding. In light of the emergent quality of communication Stewart has developed what he calls a nexting approach to communicative encounters. Nexting is an intentional way of being-with others in communication that is cognizant of what might happen after words are spoken. Nexting is a responsive awareness to the incomplete nature of the communication event. ${ }^{6}$

Significantly, invitational hermeneutics, which begin from the recognition that our understanding is limited, contextual, and incomplete contribute to possibilities for dialogic practices of communication. However, rather than attempting to negotiate every communicative event with the constant pressure of what to do and say next, the invitational hermeneutic I propose grounds conversation in the present and makes no demand on the future. Following Gadamer's call to questioning and realizing that things are always more than, invitational hermeneutics situate practices of care within present awareness of the responsive possibilities for individual understanding in relation with others. Invitational hermeneutics make way for caring opportunities to as Heidegger has elucidated, "leap ahead" with others in liberative ways. Compassionate care attends to strangers beyond their material and physical needs in order that they might see hermeneutic constraints of fundamentalisms and respond otherwise. Family members 
care for one another with rehabilitative intent in order to construct homes without rigid borderlines and protective boundaries of fundamentalist homemaking. Courage and concernful reticence accompany liberative practices of community such that interpretation and response is not limited to the Enframing generalization and objectification of the social sphere. And, graceful hospitality welcomes difference as an opportunity to found communities respectful of and unconstrained by external particularities and "communitarian identities."

In addition to the emergent quality of communication, dialogic models also depend upon the "irreducibly social, relational, or interactional character of all human meaning-making." ${ }^{77}$ And, beyond identifying this relational nature, dialogic scholars of communication have also offered prescriptive, ethical possibilities for dialogue in specific relational contexts. John Stewart and Karen Zediker described the prescriptive element of dialogue, writing:

$[T]$ hese approaches identify features of contact that are not always present, may not always be desirable, and are not always possible, but that can serve as an ideal toward which communication may fruitfully move in many different contexts [...]. In other words, understood as an identifiable and achievable quality of moments of contact, dialogue can function as an edifying and enhancing communicative ideal. ${ }^{8}$

The relational quality of the communicative event suggests that practices of dialogue are ethical and contribute to more "fruitful" ways of being-with others and making meaning together. The invitational hermeneutics that I propose contribute to both the descriptive and prescriptive conceptions of dialogic communication. Invitational hermeneutics begin from the recognition that we are always making sense of things and we are always with others and objects. Upon this twofold understanding of the hermeneutic structure of existence I outlined a descriptive account of the common 
fundamentalisms that constrain our interpretation and response, and I ventured to imagine other ways of being-with.

The hermeneutic of invitation I propose recognizes the inability to ever fully or thoroughly understand another person. This understanding contributes to dialogic models of interpersonal communication by incorporating notions of reflexivity, restraint and humility into the communicative endeavor. Rather than beginning with behavioral modification, because as Stewart and Zediker rightly attest, "[t]he context-bound, relational, emergent and momentary features of dialogue make it impossible to offer a technology of specified 'moves' that will guarante[e] that an encounter will be dialogic," the invitational hermeneutic starts by questioning and in so doing grants the distance necessary to attend to possibilities of meaning long concealed by hermeneutic inclinations. ${ }^{9}$ In this way invitational hermeneutics are similar to the notion of reflexivity described by Wendy Leeds-Hurwitz as "a process of questioning [...], accepting a multiplicity of meanings in events," and the possibility of, "discover[ing] the frequently hidden 'I." ${ }^{10}$ Furthermore, invitational hermeneutics take the ongoing project of questioning to the immediate, moment by moment communicative encounter in ways resonant with what Rebecca Z. Shafir has described as mindfulness. For Shafir, mindful listening is a sensuate undertaking of compassionate desire whereby communicators are connected with one another so that things "typically taken for granted," 11 can come alive. Contrasting mindfulness with mindlessness Shafir writes: "Mindfulness connects us with the experience of the moment, no matter what the activity. With listening, mindfulness connects us to the listener. Mindlessness, on the other hand, means letting the ego-dominated self - concerns with status, past experiences, and other barriers - separate us from the listener." ${ }^{12}$ Mindfulness connects the communicator with the world of another in ways similar to the sense-able invitational hermeneutic I propose, and is the catalyst for mutual awakening. 


\section{Future Research/Direction}

Given the varied nature of fundamentalisms and the multiple hermeneutic possibilities for being-with others there are many areas of questioning that will direct my future research. The first line of examination concerns the nature of invitation. Though I have described hopeful possibilities of interpreting and responding to difference within invitational hermeneutics I have not addressed the troubled character of the invitational encounter. Some of the questions that arise when considering invitation are: Who is inviting whom? What might it mean to have a conversation where all parties are given equal space for invitation? And, how does the use of particular stories limit invitational possibilities? These questions take me back to feminist concerns and compel me to further investigation regarding issues of power and privilege in every relational context.

Beyond feminist considerations of the privileged character of invitation, my future research agenda includes consideration of the corporeal possibilities or implications of the invitational hermeneutic practices of compassion, rehabilitation, concernful reticence, and hospitality. These practices of care are not relegated to abstract exercises of thought but are necessarily grounded in everyday ways of sharing worlds with people of difference. Irigaray points to the embodied nature of being-with others, writing: "The other in us must remain flesh, living, moving. Not transformed into some idea, no matter how ideal." ${ }^{, 13}$ Hermeneutics are not simply habits of thought removed from bodily dealings in the world and difference is not just a matter of cognitive dissonance. Hermeneutics and difference are always embodied. As such, the corporeal reality of being-in-the-world necessitates further consideration related to both fundamentalisms and alternative hermeneutic possibilities for being-with others.

Questions of invitation are not limited to feminist concern, and the hermeneutic I have described is theological—which is not to say denominational. The distinction between theology and denomination is of great importance to my future research. Though I might call myself a "Christian" and while faith is of fundamental concern to me, the theological import of the hermeneutic I have described is not limited to those who share the same doctrinal affiliation. Invitational hermeneutics leave open the 
possibility of question and point to a broadened understanding of sacral language concerning divinity and transcendence, as well as the everyday ways of practicing faith in communities shared by people of difference. However, fundamentalisms are often most clearly justified and frequently exhibited within faith-based communities. Furthermore, hermeneutic possibilities of compassion, rehabilitation, concernful reticence, and hospitality are not limited to specific religious narratives or particular cultural practices. The theological impulse of the invitational hermeneutic I have developed is the understanding that living with differences, however fundamental, requires openness to hear other ways and words. In order to address this struggle between fundamentalisms and alternative theological hermeneutics I must, it seems, investigate and question how invitation might work or be understood as a nondenominational feminist faith practice.

The trouble with fundamentalisms is that, as Adam Phillips has rightly described, they are fundamental to who and how we understand ourselves in the world. As such, fundamentalisms are, in most cases, deemed worth defending. An invitational hermeneutic must offer multiple possibilities for being-with others while still remaining faithful to particular fundamental concerns. Invitation is not a project of conversion-it is an interpretive construct wherein we and others are free to both declare the truths that have "claimed us" as well as attend hospitably to the differences in the spaces between. Hermeneutics of invitation provide us with a conversational model of practical theological engagement in community that is grounded in hospitality and humility, rather than rejection and arrogance or unreflective assent. However, fundamentals are of varying degree and practice and some are more fundamental to us than others. Both difference and our interpretation of that difference occur on multiple levels of understanding. Given that difference is at the heart of fundamentalist exclusionary ways of being-with as well as impoverished practices of care, future research requires attention to specific structural and historical iterations of fundamentalist hermeneutics. This work is a beginning. That is to say, the hermeneutics I have uncovered by no means exhaust the multiple interpretive possibilities for being-with others in the world. 
While the specific hermeneutics of compassion, rehabilitation, concernful reticence, and courage allow for alternative ways of interpreting and responding to difference- - the hopeful reality is that these are not the only ways. 
${ }^{1}$ Hans-Georg Gadamer, Truth and Method translated by Joel Weinsheimer and Donald G. Marshall (NY: Continuum, 2004), 293-294.

${ }^{2}$ Luca D’Isanto, “Introduction” Belief, 7.

${ }^{3}$ See David W. Johnson, "Building Relationships with Diverse Others," in Bridges Not Walls: A Book About Interpersonal Communication edited by John Stewart (NY: McGraw-Hill Companies, 2012), 453-461.

${ }^{4}$ Hans-Georg Gadamer, Truth and Method translated by Joel Weinsheimer and Donald G. Marshall (NY: Continuum Books, 2006), xxvi.

${ }^{5}$ John Stewart, “A Contribution to Ethical Theory and Praxis" in The Handbook of Communication Ethics edited by George Cheney, Steve May, and Debashish Munshi (NY: Routledge, 2010), 23.

${ }^{6}$ Stewart, "A Contribution to Ethical Theory and Praxis," 25-26.

${ }^{7}$ John Stewart and Karen Zediker, "Dialogue as Tensional Ethical Practice," in Southern Communication Journal vol. 65, nos. 2-3 Winter-Spring 2000, 225.

${ }^{8}$ Stewart and Zediker, "Dialogue as Tensional Ethical Practice,” 228.

${ }^{9}$ Stewart and Zediker, "Dialogue as Tensional Ethical Practice,” 231.

${ }^{10}$ Wendy Leeds-Hurwitz, "Forum Introduction: Social Approaches to Interpersonal Communication," in Communication Theory, vol.2, 1992, 131-139.

${ }^{11}$ Rebecca J. Shafir, "Mindful Listening," in Bridges Not Walls: A Book About Interpersonal Communication edited by John Stewart (NY: McGraw-Hill Companies, 2012), 191.

${ }^{12}$ Rebecca J. Shafir, “Mindful Listening,” 191.

${ }^{13}$ Luce Irigaray, The Way of Love translated by Heidi Bostic and Stephen Pluháček (NY: Continuum, 2002), 156. 


\section{Bibliography}

Arendt, Hannah. The Human Condition (Chicago, IL: University of Chicago Press, 1958), 39.

Ayers, David J. “Chapter 18: The Inevitability of Failure: The Assumptions and Implementations of Modern Feminism," in Recovering Biblical Manhood and Womanhood: A Response to Evangelical Feminism edited by John Piper and Wayne Grudem (Wheaton, IL: Crossway Books, 2006).

Badiou. Alain, Saint Paul: The Foundation of Universalism translated by Ray Brassier (Stanford, CA: Stanford University Press, 2003).

Badiou. Second Manifesto for Philosophy, translated by Louise Burchill (Malden, MA: Polity Press, 2011).

Belfast Telegraph. "We needn’t fear these radical nomads," 17 April 2010.

Bostic, Heidi. “Luce Irigaray and Love,” Cultural Studies 16.5 (2002).

Clemens, Justin. "The Science of Fundamentalism," in http://ethicalpolitics.org/seminars/justin-clemens.htm, 2006.

Collins, Sheila D. A Different Heaven and Earth (PA: Judson Press, 1974) in cited by Pauli Murray in "Salvation and Liberation," sermon reprinted and edited by Bettye Collier-Thomas, Daughters of Thunder: Black Women Preachers and Their Sermons, 1850-1979 (San Francisco, CA: Josey Bass, 1998). 
Davis, Ellen F. Who Are You, My Daughter? Reading Ruth Through Image and Text, (Louisville, KY: Westminster John Knox Press, 2003).

Erikson, Millard J. Christian Theology (Grand Rapids: MI, Baker Book House, 1985).

ESV $V^{\circledR}$ Bible (The Holy Bible, English Standard Version ${ }^{\circledR}$ ), copyright 2001 by Crossway Bibles, a publishing ministry of Good News Publishers. Used by permission. All rights reserved.

Gadamer, Hans-Georg. Truth and Method translated by Joel Weinsheimer and Donald G. Marshall (NY: Continuum, 2004).

Gergen, Kenneth J. Reltional Being: Beyond Self and Community (NY: Oxford University Press, 2009).

Gilligan, Carol. In a Different Voice: Psychological Theory and Women's Development, (MA: Harvard University Press, 1993).

Heywood, Leslie and Jennifer Drake editors, Third Wave Agenda: Being Feminist, Doing Feminism (MN: University of Minnesota Press, 1997).

Irigaray, Luce. An Ethics of Sexual Difference Translated by Carolyn Burke and Gillian C. Gill (NY: Continuum, 2004).

Irigaray. Between East and West from Singularity to Community. Translated by Stephen Pluháček.(NY: Columbia University Press, 2002).

Irigaray. I Love to You, translated by Alison Martin (NY: Routledge, 1996). 
Irigaray. Sharing the World (London: Continuum, 2008).

Irigaray. This Sex Which is Not One, Translated by Catherine Porter with Carolyn Burke (Ithaca, NY: Cornell University Press, 1985).

Irigaray. Way of Love, translated by Heidi Bostic and Stephen Pluháček (NY:

Continuum, 2002).

Jacobson, Kirsten. "The Experience of Home and the Space of Citizenship," in The Southern Journal of Philosophy, vol 48, no. 3, September 2010.

Jantzen, Grace. Becoming Divine: Towards a Feminist Philosophy of Religion (IN: Indiana University Press, 1999).

Jones, Serene. Feminist Theory and Christian Theology: Cartographies of Grace (Minneapolis, MN: Fortress Press, 2000).

Jones, "Feminist Theology and the Global Imagination," in The Oxford Handbook of Feminist Theology eds. Mary McClintock Fulkerson and Sheila Briggs (NY: Oxford University Press, 2012).

Kearney, Richard. On Stories (NY: Routledge, 2002), 137.

Kierkegaard, Søren. Works of Love. Translated and edited by Howard B. Hong and Edna H. Hong (Princeton, NJ: Princeton University Press, 1995).

Koehn, Daryl. Rethinking Feminist Ethics: Care, trust and empathy, (London: Routledge, 1998), 24. 
Leeds-Hurwitz, Wendy. "Forum Introduction: Social Approaches to Interpersonal Communication," in Communication Theory, vol.2, 1992.

Levinas, Emmanuel Totality and Infinity, translated by Alphonso Lingis (Pittsburgh, PA: Duquesne University Press, 1969).

Martin Heidegger, Being and Time, edited by John Macquarrie and Edward Robinson. (NY: Harper \& Row Publishers, 1962).

Martin, Biddy and Chandra Talpade Mohanty. "Feminist Politics: What's Home Got to Do with it?" in Feminist Studies/Critical Studies edited by Teresa de Lauretis (Bloomington, IN: Indiana University Press, 1986).

McClintock Fulkerson, Mary and Sheila Briggs, eds. The Oxford Handbook of Feminist Theology (NY: Oxford University Press, 2012).

Messina-Dysert, Gina. "Selfish Working Mothers Destroying the Natural Order? http://feminismandreligion.com/, June 5, 2013

Moore, Carey A. The Anchor Bible Daniel, Esther, and Jeremiah The Additions. (NY: Doubleday \& Company, 1977).

Peperzak, Adriaan Theodoor. Philosophy Between Faith and Theology: Addresses to Catholic Intellectuals (IN: University of Notre Dame Press, 2005).

Phillips, Adam. "On What is Fundamental" in Salmagundi, vol. 162/163, Spring 2009.

Radford Ruether, Rosemary New Woman, New Earth: Sexist Ideologies and Human Liberation (MA: Beacon Press, 1995). 
Radford Ruether, Sexism and God-Talk: Toward a Feminist Theology (MA: Beacon Press, 1993).

Ramsey Eric Ramsey, The Long Path to Nearness: A Contribution to a Corporeal Philosophy of Communication and the Groundwork for an Ethics of Relief (Atlantic Highlands, NJ: Humanities Press International, Inc., 1998).

Ruthven, Malise. Fundamentalism: A Very Short Introduction (NY: Oxford University Press, 2007).

Shafir, Rebecca J. "Mindful Listening," in Bridges Not Walls: A Book About Interpersonal Communication edited by John Stewart (NY: McGraw-Hill Companies, 2012).

Soyinka, Wole. "Mali and the Mad Clerics: Africa's Al-Qaida Clones are Not Religious, We Are Facing Viral Mutations of the Human Psyche," in The Guardian, 2 February 2013, 36.

Spelman, Elizabeth V. Inessential Woman: Problems of Exclusion in Feminist Thought (Boston, MA: Beacon Press, 1988).

Stewart, John and Karen Zediker, "Dialogue as Tensional Ethical Practice," in Southern Communication Journal vol. 65, nos. 2-3 Winter-Spring 2000.

Stewart, John. "A Contribution to Ethical Theory and Praxis" in The Handbook of Communication Ethics edited by George Cheney, Steve May, and Debashish Munshi (NY: Routledge, 2010). 
Sutherland, Arthur. I Was a Stranger: A Christian Theology of Hospitality (Nashville, TN: Abingdon Press, 2006).

Vattimo, Gianni. Belief translated by Luca D'Isanto and David Webb (Stanford, CA: Stanford University Press, 1999).

Venker, Suzanne. The War on Men (Washington, DC: WND Books, 2013).

White, E.B.Charlotte's Web (NY: Harper Collins Children's Books, 1952).

Wier, Allison. "Home and Identity: In Memory of Iris Marion Young," in Hypatia, vol. 23, no. 3, July-September 2008.

Wilson, James Q. “The Family-Values Debate,” in Commentary Magazine, vol 94, no. 5, April 1993.

http://www.pewsocialtrends.org/2013/05/29/breadwinner-moms/ 